University of Rhode Island

DigitalCommons@URI

Open Access Dissertations

2014

\title{
AMERICAN WOODCOCK ECOLOGY AND BIRD CONSERVATION IN RELATION TO FOREST MANAGEMENT
}

Roger J. Masse

University of Rhode Island, rjmasse@my.uri.edu

Follow this and additional works at: https://digitalcommons.uri.edu/oa_diss

\section{Recommended Citation}

Masse, Roger J., "AMERICAN WOODCOCK ECOLOGY AND BIRD CONSERVATION IN RELATION TO FOREST MANAGEMENT" (2014). Open Access Dissertations. Paper 228.

https://digitalcommons.uri.edu/oa_diss/228

This Dissertation is brought to you for free and open access by DigitalCommons@URI. It has been accepted for inclusion in Open Access Dissertations by an authorized administrator of DigitalCommons@URI. For more information, please contact digitalcommons-group@uri.edu. 


\author{
AMERICAN WOODCOCK ECOLOGY AND BIRD \\ CONSERVATION IN RELATION TO FOREST \\ MANAGEMENT \\ BY \\ ROGER J. MASSE
}

A DISSERTATION SUBMITTED IN PARTIAL FULFILLMENT OF THE REQUIREMENTS FOR THE DEGREE OF DOCTOR OF PHILOSOPHY

IN

ENVIRONMENTAL SCIENCES

UNIVERSITY OF RHODE ISLAND 


\section{DOCTOR OF PHILOSOPHY DISSERTATION}

OF

ROGER J. MASSE

APPROVED:

Dissertation Committee:

$\begin{array}{ll}\text { Major Professor } & \text { Scott R. McWilliams } \\ & \text { Peter V. August } \\ & \text { Liliana M. Gonzalez }\end{array}$

Nasser H. Zawia

DEAN OF THE GRADUATE SCHOOL

UNIVERSITY OF RHODE ISLAND

2014 


\begin{abstract}
The extent of shrubland and young forest in the Northeast, USA, has declined rapidly since the mid-1900's. Accordingly, the abundance of wildlife that depends on young forest has also declined. For example, American woodcock (Scolopax minor), an upland shorebird species, require an appropriate spectrum and spatial configuration of young forest to thrive and their populations have declined significantly since at least 1968. Active forest management is required to conserve populations of American woodcock and other young forest wildlife, but the importance of young forest management to some aspects of the ecology of key wildlife are not fully understood. I investigated three aspects of American woodcock ecology in relation to young forest management in Rhode Island, USA. First, I monitored the daytime locations of radiomarked American woodcock to assess habitat selection at multiple scales in relation to young forest management. Second, I also monitored American woodcock movements between daytime and nighttime locations and quantified food availability and predator activity at these sites to test the foraging-benefit and predation-risk hypotheses that were proposed to explain American woodcock commuting behavior. Third, I compared landbird communities at managed forest openings used by breeding American woodcock and nearby random forest sites to determine whether American woodcock habitat management benefits non-target landbirds and so verifies adopting American woodcock as an umbrella species useful for conservation.

Daytime habitat selected by American woodcock comprised areas of younger forest where the biomass of preferred food (i.e., earthworms [Haplotaxida]) was 1.7 3.1 times greater, and the density of shrub and sapling stems was two times greater,
\end{abstract}


compared to random sites. American woodcock home ranges were typically $<50$ ha and encompassed wetland forests and deciduous or mixed upland forests on flatter slopes $\leq 1.5 \mathrm{~km}$ from streams, agricultural openings, upland young forests, and moist soils. Across Rhode Island, most forested land was in the low - moderate classes of relative probability of use, but young forest management in key areas effectively increased relative use. I illustrated how land managers can use resource selection functions to predict the response of American woodcock to young forest management and so maximize conservation benefits.

All of the American woodcock I monitored commuted between dense forest stands and forest openings during the day and night, respectively. I found no support for the foraging-benefit hypothesis because individuals moved from daytime locations where earthworms were $3-4$ times more abundant to nighttime locations where preferred food was scarce. Soil moisture content was greater at daytime than nighttime locations which may explain why earthworms were more prevalent at those sites. In contrast, I found support for the predation-risk hypothesis because individuals moved from daytime locations where mammalian predators were more active to nighttime locations where mammalian predators were less active. Thus, American woodcock commuted between daytime and nighttime locations to avoid predators and not to feed. Maintaining forest openings is an important part of American woodcock habitat management so that individuals can eat by day and stay safe by night.

I identified 38 - 51 bird species during 10-minute point counts at American woodcock singing grounds and random forest sites, and $62-73 \%$ of the more frequently occurring species were more common at American woodcock singing 
grounds. On average, 55\% of the more common species at American woodcock singing grounds were of high regional or local conservation priority. Young forest species such as prairie warbler (Setophaga discolor) and gray catbird (Dumetella carolinensis) were more abundant at American woodcock singing grounds and scarce or absent at random forest sites while the opposite was true for more mature forest species such as ovenbird (Seiurus aurocapilla) and red-eyed vireo (Vireo olivaceus). Moreover, the total number of birds (all species combined) and diversity of birds were $\geq 1.5$ times greater at American woodcock singing grounds than random forest sites. Critical breeding sites for American woodcock can be managed by clearcutting $\geq 2$-ha patches of older secondary forest and many other young forest bird species of conservation priority inhabit these managed areas. Thus, the American woodcock can serve as an effective umbrella species for young forest birds in the Northeast, USA, but complementary umbrella species such as the ovenbird should be considered to aid in the conservation of more mature forest birds. 


\section{ACKNOWLEDGMENTS}

I greatly appreciate the time, whether in the office, field, or home, that my advisor, Scott McWilliams, and state collaborator, Brian Tefft, devoted to me during my tenure at University of Rhode Island. Scott, I think it is safe to say that you often pushed me to think more broadly, creatively, and critically about my research than I would have without your guidance. For this I am grateful. I also thank you, Scott, for the many opportunities you provided (e.g., attending conferences, co-advising Coastal Fellow and MESM students, teaching NRS 309, etc...) that helped develop my professional interests and skills. Brian, I very much enjoyed our chats in your office and the applied management perspective that you helped infuse into my research interests. I also appreciate the opportunities you provided (e.g., attending the upland game bird technical committee meeting, conducting wild turkey surveys, conducting cottontail telemetry, etc...) that helped me gain additional experience. I am also grateful, Brian, for the encouragement you provided as I revived my passion for hunting wild turkeys, white-tailed deer, and ducks. I sincerely hope to be able to maintain collaborations with you both in the future.

I also thank my other committee members, Pete August, Liliana Gonzalez, Peter Paton, and Keith Killingbeck, for their time and guidance. Pete, your GIS wizardry is extraordinary. I fully enjoyed learning from you both inside and outside the classroom. Liliana, I appreciate your applied approach to teaching statistics. Thank you for your patience while helping me better understand the subject. Peter, the discussions you encouraged during Biology and Management of Migratory Birds were thoughtprovoking and helped broaden my interests in bird conservation issues. Thank you. 
Keith, I appreciate your genuine interest in the timberdoodles I studied and I would have enjoyed having you accompany me into the field while catching them. Thank you, Keith, for serving as chair of my defense committee.

I extend endless thanks to the diligent Coastal Fellows and field technicians without whom my research would not have been possible. To my first Coastal Fellow, Tiffany Heywood, I hope that you learned as much from me as I did from you. Thank you for inspiring me to investigate in more detail the summer commuting behavior of woodcock. To my second and third Coastal Fellows, Amanda Padula and Wes Shean, thank you for your hard work during hot days and humid nights. I also appreciate the diversity of interests that you brought to your respective fellowship projects. To my fourth and fifth Coastal Fellows, Donnamarie Duffin and Lindsey Barnard, I am grateful for your dedication to my research and your respective fellowship projects. Thank you, Donnamarie, for winning one of the "big" checks with your fellowship poster and solidifying our place in Coastal Fellows history. Lindsey, I appreciate the work ethic and positive attitude that you brought into the field each day. I am also grateful for the time and effort you provided as an undergraduate teaching assistant for NRS 309. To my field technicians, Sean Camillieri, John Veale, Jon Travers, and Wes Shean, thank you for your hard work and attention to detail while tracking woodcock and collecting habitat data. Each of your efforts contributed to the success of my research. I also extend sincere thanks to the dozens of volunteers who helped catch the woodcock that I studied.

I appreciate the time and attention of Dan McAuley, Deb Bourassa, and the members (both past a present) of the McWilliams Lab. Dan, thank you for visiting 
Rhode Island during the earlier stages of my research. I very much enjoyed learning about woodcock ecology from you. Deb, your knowledge of the administrative ins and outs of the Department, College, and University are unrivaled. Thank you for making sure that forms were submitted when and where they needed to be, tracking down a spare key when I locked myself out of a Department truck, and scheduling rooms for various meetings and presentations. To members of the McWilliams Lab, thank you for listening to many woodcock-related presentations and for helping to improve the quality of these with your questions, comments, and suggestions. I also thank Adam Smith for helping with statistical analyses, Josh Beuth for serving as a teaching assistant during NRS 309 and for encouraging me to spend more time hunting and fishing, and Kris Winiarski for enriching my outdoor experiences from the salty waters of Narragansett Bay to the forests and creeks of South Kingstown.

Funding for my research was provided by a variety of sources including the Rhode Island Department of Environmental Management via USFWS Federal Aid to Wildlife Investigations Project W-23R, the US Department of Agriculture McIntyreStennis (MS-975) and Hatch (H-333) Grants, the Rhode Island Agricultural Experiment Station, and the Graduate School and Department of Natural Resources Science at University of Rhode Island. I thank all of those whose efforts helped to secure the funding that supported me.

Last but not least, my deepest thanks go to my family for their continued support, belief, and love over the years. Mom, I greatly appreciate the resources you provided which have enabled me to pursue my interests and college education. Dad, thank you for reminding me to take time to enjoy my surroundings. Don, Ron, and Chris, thank 
you for the teasing and harassment that only brothers and step-brothers can provide. You have helped shape the person that I am today. Woody, Joan, Cedric, Sharon, Lynne, and Margaret, thank you for your support over the years. I consider myself lucky to have you as a second family. Finally, I am forever grateful to Jessica. Eleven years ago you convinced me to pursue an undergraduate education. I'm fairly certain you never thought we would be here today, but you accompanied me along the way, first to Delaware and then to Rhode Island, as I subsequently earned my graduate degrees. Your steadfast love and support have guided me through this unexpected journey. Thank you, Jessica, for always keeping me grounded, encouraging and inspiring me to be a better man, spending hours entering various types of data, staying up until 2 a.m. to greet me when I returned home from tracking woodcock at night, keeping me light-hearted through it all, and, most importantly, being the wife that you are. I love and cherish you. 


\section{DEDICATION}

This dissertation is dedicated to the memories of:

Matt Hance, a great friend and step-brother;

Larry Mayo, a fellow sportsman and skilled cribbage player;

Bob Hance, a loving step-father;

and

Charles Resseguie, an old-timer whose stories were always worth listening to. I wish each of you were still here to help celebrate my accomplishments. 


\section{PREFACE}

This dissertation was prepared according to the Manuscript Format guidelines established by the Graduate School at University of Rhode Island. Manuscript 1, "Multiscale Habitat Selection by a Forest-dwelling Shorebird, the American Woodcock: Implications for Forest Management in Southern New England, USA”, is formatted for publication in the journal Forest Ecology and Management. Manuscript 2, "Why Woodcock Commute: Testing the Foraging-benefit and Predation-risk Hypotheses", is formatted for publication in the journal Behavioral Ecology. Manuscript 3, "Is American Woodcock Habitat Management for the Birds? Verifying the Woodcock as an Umbrella Species for Landbirds in the Northeast, USA", is formatted for submission to the journal Biological Conservation. 


\section{TABLE OF CONTENTS}

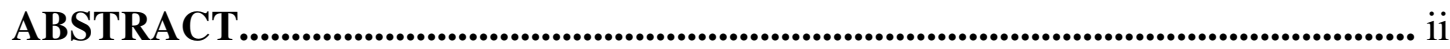

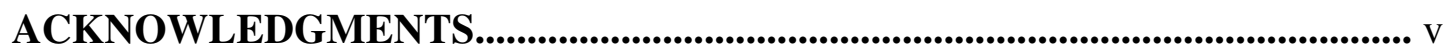

DEDICATION

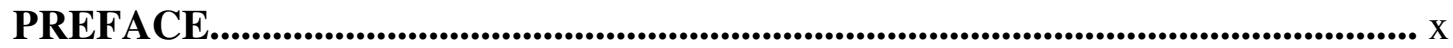

TABLE OF CONTENTS......................................................................................... xi

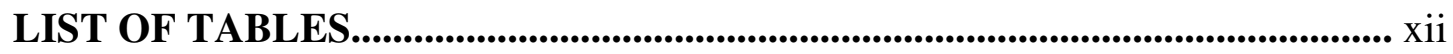

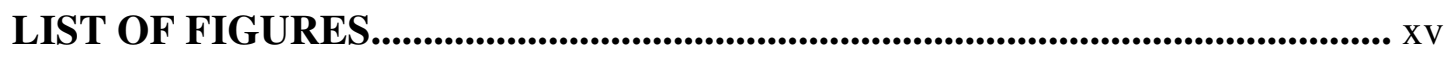

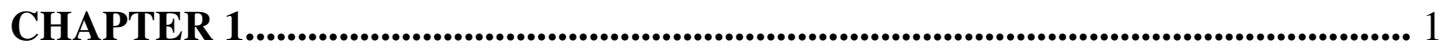

"Multiscale Habitat Selection by a Forest-dwelling Shorebird, the American

Woodcock: Implications for Forest Management in Southern New England,

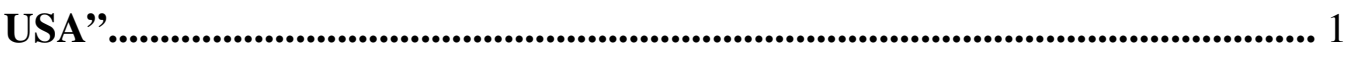

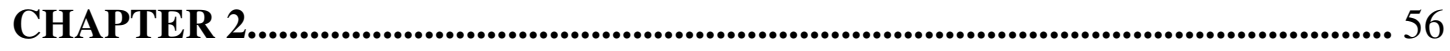

"Why Woodcock Commute: Testing the Foraging-benefit and Predation-risk

Hypotheses"

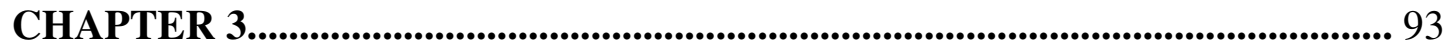

"Is American Woodcock Habitat Management for the Birds? Verifying the

Woodcock as an Umbrella Species for Landbirds in the Northeast,

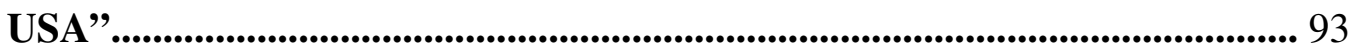




\section{LIST OF TABLES}

TABLE

PAGE

\section{CHAPTER1}

Table 1. Initial and remaining number of radio-tagged male woodcock in Kent and

Washington Counties, Rhode Island, USA

Table 2. Non-transformed range, mean $\pm \mathrm{SE}$, and median values for variables associated with the forest overstory, food resource, and forest understory habitat components measured inside and outside the primary diurnal coverts of male woodcock in Kent and Washington Counties, Rhode Island, USA.

Table 3. Coefficient values $(\beta)$ for each of the variables included in the three highestranked resource selection functions relating the relative probability of use by woodcock of forested land to geographic variables in Rhode Island, USA 47

CHAPTER 1, Appendix A

Table A.1. Loadings (correlations) for retained principle components in relation to 13 quantitative habitat variables measured inside and outside the primary diurnal coverts of male woodcock in Kent and Washington Counties, Rhode Island, USA............... 52 Table A.2. Fifteen a priori logistic regression models used to derive coefficients for resource selection functions relating the relative probability of use by woodcock of forested land to geographic variables in Rhode Island, USA 


\section{CHAPTER 2}

Table 1. Average density $\left(\right.$ no. $\left./ \mathrm{m}^{2}\right)$ of potential prey found in the soils at the diurnal coverts and nocturnal roost fields of 17 radio-marked American woodcock males during August 2011 in Rhode Island, USA........................................................ 86

Table 2. Average density $\left(\right.$ no. $/ \mathrm{m}^{2}$ ) of potential prey found in the soils at the diurnal coverts and nocturnal roost fields of 21 radio-marked American woodcock (20 males and one female) during July - August 2012 in Rhode Island, USA 88

\section{CHAPTER 3}

Table 1 . Bird species with a mean \pm SE frequency of occurrence $\geq 0.20$ at woodcock singing grounds or random forest sites from 27 May - 2 July 2011 - 2013 at Arcadia Wildlife Management Area in Kent and Washington Counties, Rhode Island,

USA. 124

Table 2. Bird species with a mean \pm SE frequency of occurrence $\geq 0.20$ at woodcock singing grounds or random forest sites from 27 May - 2 July 2012 - 2013 at Big River Wildlife Management Area in Kent and Washington Counties, Rhode Island, USA.

Table 3. Bird species with a mean \pm SE frequency of occurrence $\geq 0.20$ at woodcock singing grounds or random forest sites from 27 May - 2 July 2011 - 2013 at Great Swamp Wildlife Management Area in Washington County, Rhode Island, USA. 128 
CHAPTER 3, CONTINUED, Appendix A

Table A.1. Common and scientific name, long-term population trend, and mean frequency of occurrence for bird species observed during 10-minute point count surveys at woodcock singing grounds and random forest sites at Arcadia, Big River, and Great Swamp Wildlife Management Areas in Kent and Washington Counties, Rhode Island, USA.

Table A.2. Mean \pm SE relative abundance (no. of individuals per 50-m plot) for bird species observed during 10-minute point count surveys at woodcock singing grounds and random forest sites at Arcadia, Big River, and Great Swamp Wildlife Management Areas in Kent and Washington Counties, Rhode Island, USA 


\section{LIST OF FIGURES}

FIGURE

PAGE

\section{CHAPTER 1}

Figure 1. Mean scores for the forest overstory (a), food resource (b), and forest understory (c) habitat components sampled inside and outside the primary diurnal coverts of male woodcock in Kent and Washington Counties, Rhode Island, USA

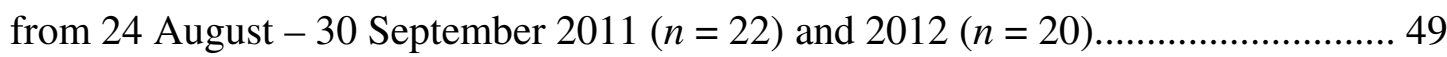
Figure 2. Relative probability of use by woodcock of forested land (a) and areas of older second-growth upland forest, generally 60 - 100 years, where woodcock habitat management might be most beneficial for increasing relative use (b) in Rhode Island, USA

Figure 3. Relative probability of use by woodcock of forested land in a case study area in Arcadia Wildlife Management Area in southwestern Rhode Island, USA, that is considered for forest management (a). The hypothetical forest management scenario considered for this site (b) included creating 30 ha of upland young forest and 10 ha of herbaceous forest openings (e.g., wildlife openings or old fields) in areas of older second-growth upland forest (e.g., 60 - 100 years) deemed most beneficial for woodcock habitat management. Following management (c), the estimated extent of low relative use by woodcock of the managed forest decreased by 92 ha while the estimated extents of low-moderate, moderate, and moderate-high relative use increased by 26 ha, 38 ha, and 16 ha, respectively 


\section{CHAPTER 2}

Figure 1. Average differences in earthworm fresh and dry weight (a), median difference in the cumulative density of known prey (b), and average differences in richness and diversity of soil macrofauna (c) at the diurnal coverts and nocturnal roost fields of radio-marked American woodcock (2011: 17 males; 2012: 20 males and one female) during July-August in Rhode Island, USA. 90

Figure 2. Difference in the number of nights that any mammalian predator visited a baited track station at the diurnal covert and nocturnal roost field for 11 radio-marked American woodcock males during September 2011 in Rhode Island, USA.

Figure 3. Difference in the number of days until initial predator visit at the diurnal covert and nocturnal roost field for each of 12 radio-marked American woodcock males during August 2012 in Rhode Island, USA

\section{CHAPTER 3}

Figure 1. Relative abundances (mean no. of individuals per 50-m plot) for the bird species observed with the three highest frequencies of occurrence at woodcock singing grounds and random forest sites at Arcadia (a), Big River (b), and Great Swamp (c) Wildlife Management Areas in Kent and Washington Counties, Rhode Island, USA.

Figure 2. Proportions of forest cover types at Arcadia, Big River, and Great Swamp Wildlife Management Areas in Kent and Washington Counties, Rhode Island, USA (a). Mean number (b) and diversity (c) of birds per 50-m plot at woodcock singing grounds and random forest sites at each management area. 


\section{CHAPTER 3, CONTINUED}

Figure 3. Sample-based rarefaction curves showing the cumulative number of species expected (solid lines) at woodcock singing grounds and random forest sites at Arcadia (a), Big River (b), and Great Swamp (c) Wildlife Management Areas in Kent and

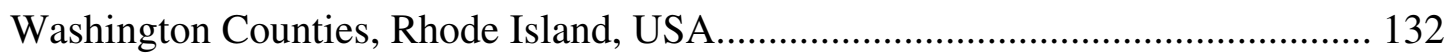




\section{CHAPTER 1}

"Multiscale Habitat Selection by a Forest-dwelling Shorebird, the American Woodcock: Implications for Forest Management in Southern New England, USA"

by

Roger J. Masse ${ }^{1,3}$, Brian C. Tefft ${ }^{2}$, and Scott R. McWilliams ${ }^{1}$

is accepted for publication in Forest Ecology and Management

${ }^{1}$ Department of Natural Resources Science, University of Rhode Island, 102 Coastal Institute in Kingston, Kingston, RI 02881, USA.

${ }^{2}$ Rhode Island Department of Environmental Management, Division of Fish and Wildlife, 277 Great Neck Road, West Kingston, RI 02892, USA.

${ }^{3}$ Corresponding author; e-mail: rjmasse@ my.uri.edu. 


\section{Abstract}

Declines of young forest and associated populations of wildlife are major conservation concerns in the Northeast, USA. Active forest management is required to conserve declining populations of young forest wildlife and investigating habitat selection by target species can help inform management decision-making. The American woodcock (Scolopax minor) is a key indicator species of young forest and their populations have declined significantly since 1968 . We investigated multiscale habitat selection by woodcock in Rhode Island, USA, in order to characterize their daytime habitat, and to predict state-wide relative probability of use by woodcock of forested land. We used radio-telemetry to monitor the daytime locations of woodcock at three state wildlife management areas from 23 May - 25 August 2011 and 2012. Compared to random sites, woodcock selected younger forest where the biomass of preferred food (i.e., earthworms [Haplotaxida]) was $46-67 \%$ greater and the density of shrub and sapling stems was about two times greater. Most woodcock home ranges were $<50$ ha and usually comprised wetland forests and deciduous or mixed upland forests on flatter slopes that were closer to streams, agricultural openings, upland young forests, and moist soils. We used resource selection functions, to determine a) that the majority of forested land in Rhode Island was in the low - moderate classes of relative use and b) that $92 \%$ of older second-growth upland forest in the state is located where woodcock habitat management would be beneficial for increasing relative use. We illustrate how land managers can use resource selection functions to compare expected responses of woodcock to alternative forest management scenarios and so maximize conservation benefits. 


\section{Introduction}

Reduced extent of early-successional forest and shrubland vegetation types (hereafter young forest) in the Northeast, USA, over the last 60 years has caused declines in populations of wildlife that depend on young forest (Askins, 2001; DeGraaf and Yamasaki, 2003; Dettmers, 2003; Trani et al., 2001). Historically, natural disturbance regimes such as wind, fire, and ice storms, and biological agents including insects, pathogens, beavers (Castor canadensis), and Native Americans sustained patchworks of young forest (Askins, 2001; Day, 1953; Foster and Aber, 2004; Lorimer, 2001). Prior to European settlement, young forest may have occupied up to $13 \%$ of the land area in some regions of eastern North America (Lorimer, 2001), but following European settlement, intensive logging and conversion of land from forest to agriculture formed a largely non-forested landscape which eventually produced an influx of young forest across the Northeast. Indeed, in central New England, USA, $>75 \%$ of remaining forests were $<30$ years old during the late-1800's (Foster et al., 1998). However, since the 1960's, the amount of young forest in the region declined from about $30-35 \%$ to $\leq 3 \%$ (Buffum et al., 2011; Trani et al., 2001). Consequently, active forest management is now required to conserve populations of young forest wildlife (DeGraaf and Yamasaki, 2003; Schlossberg and King, 2007), and habitat selection by target species should be investigated using quantitative methods to promote more informed and efficient forest management decision-making.

Classical approaches to investigating habitat selection involve comparing attributes of habitat or food measured at sites used by target species and sites unused by or available to target species (Johnson, 1980; Manly et al., 2002). For example, 
studies comparing vegetation structure at nest or roost sites and random sites using traditional null hypothesis testing help describe habitat features associated with reproduction or occupancy for forest birds (e.g., McAuley et al., 1996; Miller and Jordan, 2011; Zahner et al., 2012) and mammals (e.g., Hackett and Pagels, 2003; O’Keefe et al., 2009). More recently, studies of habitat selection have transitioned towards using resource selection functions (RSFs) to understand how probability of use by target species is influenced by environmental covariates (Johnson et al., 2006; Manly et al., 2002; McDonald, 2013). Importantly, these analysis methods allow multiple competing hypotheses to be easily tested using an information-theoretic approach (Anderson et al., 2000; Johnson et al., 2006), facilitate studies of habitat selection across multiple spatial scales (e.g., Johnson et al., 2004), and can be used to predict shifts in probability of use by target species in response to environmental change (e.g., Brown et al., 2007). We investigated habitat selection by American woodcock (Scolopax minor) using both traditional and contemporary analysis methods in order to inform young forest management in the Northeast.

The American woodcock (hereafter woodcock) is a key indicator species of young forest because populations thrive only in landscapes with an appropriate mixture of young forest ranging from forest openings to approximately 30 -year-old forest stands (Kelley et al., 2008). Woodcock breed across the eastern USA and adjacent southern and southeastern Canada and winter mainly across the southern half of the eastern USA (Sheldon, 1967), and their populations have declined significantly since 1968 (Cooper and Rau, 2012). Although woodcock are a popular game bird, woodcock survival is similar between hunted and non-hunted sites and so recreational hunting is 
not believed to be contributing to observed population declines (McAuley et al., 2005). Instead, loss and degradation of preferred young forest is the principal factor driving population declines (Dessecker and McAuley, 2001; Kelley et al., 2008; McAuley et al., 2005). High densities of small tree and shrub or sapling stems characteristic of young forests provide protective cover from diurnal predators (Dessecker and McAuley, 2001; Keppie and Whiting, 1994; McAuley et al., 1996; Straw et al., 1986) whereas recent forest clearcuts, maintained or abandoned agricultural fields, tree plantations, and other forest openings provide critical breeding areas during spring crepuscular periods (Sheldon, 1967), safe roosting areas during summer nights (Dunford and Owen, 1973; Masse et al., 2013), and feeding or roosting areas during fall and winter nights (Blackman et al., 2012; Connors and Doerr, 1982; Krohn et al., 1977).

In this study, we investigated habitat selection by woodcock in important stateowned wildlife management areas in Rhode Island, USA, where young forest was limited, but actively being created. Young forest occupies only 3\% of the land area in Rhode Island (Buffum et al., 2011) and an estimated $377 \mathrm{~km}^{2}$ of new young forest is recommended to restore woodcock densities (Kelley et al., 2008). Our objectives were to 1) characterize the daytime habitat selected by woodcock, 2) predict and map the relative probability of use by woodcock of forested land across Rhode Island, and 3) illustrate how land managers can forecast how forest management practices aimed at creating woodcock habitat influence relative use of the surrounding landscape. Addressing these objectives will increase knowledge of woodcock habitat selection in areas where preferred young forest is uncommon and permit more informed forest 
management decision-making. We predicted that woodcock would select areas of younger forest where preferred food (i.e., earthworms [Haplotaxida]) and shrub or sapling stems were more abundant, and that creating upland young forest and forest openings via forest clearcutting at sites deemed most beneficial for woodcock habitat management would increase relative use of the surrounding landscape.

\section{Methods}

\subsection{Study area}

We investigated woodcock habitat selection in three state wildlife management areas (Arcadia, Big River, and Great Swamp) in Kent and Washington Counties, Rhode Island. Each management area was dominated by forested cover types although the relative proportions of each differed among sites (RIGIS, 2012). Arcadia $\left(41^{\circ} 35^{\prime} 10^{\prime \prime} \mathrm{N}, 71^{\circ} 43^{\prime} 20^{\prime \prime} \mathrm{W}\right)$ was $62 \mathrm{~km}^{2}$ of which deciduous (33\%), mixed (31\%), and coniferous upland forest types (24\%) predominated, while wetland forest types (7\%) were uncommon. Big River $\left(41^{\circ} 37^{\prime} 0^{\prime \prime} \mathrm{N}, 71^{\circ} 36^{\prime} 60^{\prime \prime} \mathrm{W}\right)$ was $33 \mathrm{~km}^{2}$ and comprised deciduous (8\%), mixed (31\%), and coniferous upland forest types (45\%), while wetland forest types (6\%) were scarce. In contrast, Great Swamp $\left(41^{\circ} 27^{\prime} 15^{\prime \prime} \mathrm{N}\right.$, $\left.71^{\circ} 35^{\prime} 19^{\prime \prime} \mathrm{W}\right)$ was $15 \mathrm{~km}^{2}$ and composed of deciduous (16\%), mixed (5\%), and coniferous upland forest types (1\%), while wetland forest types (55\%) were common. Mixed oaks (Quercus spp.), hickories (Carya spp.), and red maple (Acer rubrum) dominated deciduous upland forest types while coniferous and mixed upland forest types were dominated by Eastern white pine (Pinus strobus) and oaks and pines, respectively (Enser and Lundgren, 2006). Red maple swamps were the most 
widespread wetland forest type and Atlantic white cedar (Chamaecyparis thyoides) swamps occurred locally (Enser and Lundgren, 2006).

During 1995, the Rhode Island Department of Environmental Management initiated a forest cutting program to benefit declining populations of woodcock and other wildlife associated with young forest. A series of 2-5-ha clearcuts in older second-growth forest (e.g., 60 - 100 years) were initially made at Great Swamp followed by additional forest management at that site during 2007 and 2012. Similar forest management began at Arcadia and Big River during 1996 and 2006, respectively. Future management at each site is expected to involve additional forest cutting at regular (e.g., 10-year) intervals and, where appropriate, the creation of larger (e.g., 10-ha) young forest patches. At the time of this study, Great Swamp contained the highest proportion of combined upland and wetland young forest (15\%) whereas young forest was uncommon at Arcadia (2\%) and Big River (1\%). Forest openings in the form of abandoned meadows and agricultural fields were also maintained to benefit woodcock and other wildlife, but the relative proportions of these at each site were low (i.e., $1-2 \%)$.

\subsection{Woodcock capture, marking, and tracking}

We caught woodcock from 2 April - 16 May 2011 and 2012 (IACUC protocol AN10-02-017) by placing mist-nets at known singing grounds where males engaged in crepuscular courtship displays to attract females for breeding (McAuley et al., 1993; Sheldon, 1967). We included only male woodcock in our study because females are difficult to catch with mist-nets during spring (McAuley et al., 1993). We caught 50 males during 2011 and 42 males during 2012, and determined age by examining 
plumage characteristics of wings (Sheldon, 1967). After capture, we fitted each woodcock with an Advanced Telemetry Systems two-stage transmitter (Model A5400) using cattle tag cement and a wire belly-band for attachment (package weight $\leq 4.0 \mathrm{~g}$; McAuley et al., 1993) and released birds on site.

From 23 May - 25 August 2011 and 2012, we monitored the daytime locations of each bird 3-4 times per week. We tracked radio-marked birds on foot using a threeelement antenna and approached each bird until the receiver gave an audible signal without the use of the antenna or headphones. On average, this method allowed us to approach to $\leq 18 \mathrm{~m}$ (Masse et al., 2013) and we marked exact locations in the field using a handheld GPS unit. We located each bird once during each monitoring day (0600 - 1900 EST) and stratified our telemetry schedule by time of day during subsequent weeks to ensure that the majority of the daytime period was represented in the sample of telemetry locations for each bird. Male woodcock generally concentrate daytime activity within small areas (Hudgins et al., 1985), called diurnal coverts, and so we approached marked birds from different directions on subsequent visits in order to circumscribe selected coverts. Since we were interested in summer habitat selection we included in our study only those individuals for which we obtained $>25$ locations throughout each monitoring period. Consequently, we excluded 40 woodcock because they died (2011: $n=4 ; 2012: n=4)$, slipped their transmitters $(2011: n=3 ; 2012: n=$ 4), or moved away from study sites and could not be relocated (2011: $n=16 ; 2012: n$ =9) prior to obtaining sufficient numbers of telemetry locations (Table 1). 


\subsection{Habitat sampling}

We sampled woodcock habitat at two spatial scales in order to investigate thirdand second-order selection. Third-order selection pertains to specific sites selected by individuals within their home ranges whereas second-order selection pertains to the positioning of home ranges within a broader landscape or geographical range (Johnson, 1980).

\subsubsection{Third-order selection}

For analysis of third-order selection, we considered diurnal coverts represented by clusters of telemetry locations for each bird similar to Hudgins et al. (1985). For each woodcock, clusters of five or more locations in which each location was $\leq 100 \mathrm{~m}$ of another location were defined as a diurnal covert and we delineated the boundaries of diurnal coverts using minimum convex polygons (MCP; Mohr, 1947). We delineated $1-3$ diurnal coverts for each woodcock, but each bird generally showed preference for a single diurnal covert and so we designated for each bird a primary diurnal covert that contained the most telemetry locations. If an individual woodcock selected multiple diurnal coverts with equal frequency then we randomly selected one to represent the primary diurnal covert. Primary diurnal coverts for 16 of 52 woodcock overlapped to some degree and so in situations where overlap was $>20 \%$ we randomly selected one woodcock's primary diurnal covert for inclusion. In addition, one woodcock was tracked during both years so we randomly selected one year to include for this individual. As a result, we promoted independence among the primary diurnal coverts included in this portion of our study and ensured that each woodcock (2011: $n$ 
$=11$ at Arcadia, 8 at Big River, and 3 at Great Swamp; 2012: $n=4$ at Arcadia, 7 at Big River, and 9 at Great Swamp) was represented equally.

We assessed third-order selection by measuring habitat variables in 5-m radius (0.008-ha) circular plots that were randomly located inside $(n=5)$ and outside $(n=5)$ each bird's primary diurnal covert from 24 August - 30 September 2011 and 2012. We used Geospatial Modeling Environment (Beyer, 2013) to randomly select plot locations up to $500 \mathrm{~m}$ outside each primary diurnal covert. We enforced a minimum distance of $15 \mathrm{~m}$ between plot locations to ensure that plots did not overlap. At the center of each plot, we collected a 10-cm deep soil core and determined soil $\mathrm{pH}$, soil moisture content ( $\%$ by weight), and soil organic matter content ( $\%$ by weight) following Masse et al. (2013). We also dug a 900- $\mathrm{cm}^{2}$ soil pit to 10-cm deep at the center of each plot and collected all earthworms by hand sorting soil pit contents (Dangerfield, 1997). We estimated earthworm density $\left(\# / \mathrm{m}^{2}\right)$ and measured fresh and freeze-dried earthworm weight $\left(\mathrm{g} / \mathrm{m}^{2}\right)$ to the nearest $0.001 \mathrm{~g}$. We calculated canopy closure (\%) at the center of each plot using a spherical densiometer (Lemmon, 1957) and visually estimated overstory height class (i.e., $0-3 \mathrm{~m}, 3-9 \mathrm{~m}$, or $>9 \mathrm{~m}$ ) for each plot. We measured diameter at breast height (dbh) of all live trees $(>10-\mathrm{cm} \mathrm{dbh})$ within each plot to the nearest $0.1 \mathrm{~cm}$ and used the program NED-2 (Twery et al., 2011) to determine density (\#/ha), basal area $\left(\mathrm{m}^{2} / \mathrm{ha}\right)$, and medial $\mathrm{dbh}(\mathrm{cm})$ of trees, and overstory size class (i.e., regeneration $[<2.5-\mathrm{cm} \mathrm{dbh],} \mathrm{sapling}[2.5-11.4-\mathrm{cm} \mathrm{dbh}]$, pole [11.5 - 26.7-cm dbh], small sawtimber [26.8 -41.9-cm dbh], or large sawtimber [ $\geq 42.0-\mathrm{cm} \mathrm{dbh])} \mathrm{for} \mathrm{each} \mathrm{plot.} \mathrm{We} \mathrm{also} \mathrm{recorded} \mathrm{generalized} \mathrm{overstory} \mathrm{cover} \mathrm{type} \mathrm{(i.e.,}$ deciduous upland forest, coniferous upland forest, mixed upland forest, wetland forest, 
or herbaceous) for each plot based on dominant vegetation. Lastly, within each plot we counted the number of live shrub and sapling stems $(\leq 10$-cm dbh and $\geq 1.5-\mathrm{m}$ tall $)$ in four randomly located $1-\mathrm{m}^{2}$ quadrats and calculated mean shrub and sapling density (\#/ha) for each plot.

\subsubsection{Second-order selection}

For analysis of second-order selection, we estimated the diurnal home range and core-use area for each bird during 2011 and 2012 using kernel density methods (Worton, 1989). We used Geospatial Modeling Environment (Beyer, 2013) to generate each home range (95\% contour) and core-use area (50\% contour) using a Gaussian kernel with likelihood cross-validation bandwidth estimator. The least squares crossvalidation bandwidth estimator and $\geq 30$ locations per individual have been recommended for home range studies (Seaman et al., 1999), but the likelihood crossvalidation bandwidth estimator produces better fit and less variability with moderate to small sample sizes (i.e., $\leq 50$ locations per individual; Horne and Garton, 2006). On average, we obtained 35 and 34 locations per individual during 2011 and 2012, respectively. However, we included four woodcock $(2011: n=2 ; 2012: n=2)$ with 26 - 29 locations each because the size of their home ranges and core-use areas were within the range of values for woodcock with $\geq 30$ locations. Previous research of woodcock movements and habitat selection used MCPs to determine home range size (e.g., Hudgins et al., 1985; Sepik and Derleth, 1993) and so we also calculated these home range estimates to facilitate comparisons with other studies.

We used a design I study with sampling protocol A (Manly et al., 2002) to assess second-order selection. For each site, we delineated a composite area of available 
woodcock habitat by pooling individual kernel home ranges across years and circumscribing them with a MCP. We delineated available habitat in this way because individuals frequently moved across the landscape during crepuscular periods (Masse et al., 2013) and so encountered, and selected against, areas outside of their diurnal home ranges. We delineated a composite area of used woodcock habitat for each site by pooling individual kernel core-use areas across years. Since woodcock remain in forested coverts during the day (Dessecker and McAuley, 2001; Hudgins et al., 1985) we clipped composite areas of available and used habitat by forest boundaries using ArcGIS 10.1 (Environmental Systems Research Institute, Redlands, CA). We converted composite areas of available and used woodcock habitat into separate raster grids (10- $\mathrm{m}^{2}$ pixel resolution) for each management area and generated raster-based habitat data at this standardized cell size. We obtained 1/3 arc-second elevation (Gesch et al., 2002), stream (RIGIS, 2001), soil (RIGIS, 2013), and land cover data (RIGIS, 2012), and generated separate grids for elevation (m), slope (\%), forest cover type (i.e., coniferous upland forest, deciduous upland forest, mixed upland forest, upland young forest, coniferous wetland forest, deciduous wetland forest, mixed wetland forest, and wetland young forest), and Euclidean distance (m) to the nearest stream, nearest agricultural opening (i.e., agriculture, pasture, idle agriculture, or tillable crops), nearest upland young forest, and nearest moist soil (i.e., moderately well drained, poorly drained, or very poorly drained). For each site, we randomly selected $10 \%$ of available ( $n=22,598$ at Arcadia, 16,955 at Big River, and 13,431 at Great Swamp) and used ( $n=1,275$ at Arcadia, 537 at Big River, and 1,235 at Great Swamp) 
pixels, and extracted values from the corresponding cells in the elevation, slope, forest cover type, and distance grids.

\subsection{Statistical analysis}

We treated all variables measured inside and outside primary diurnal coverts quantitatively except for generalized overstory cover type. For each of the interval variables (e.g., overstory size class) we either assigned mid-point values to each interval or, for open-ended intervals (e.g., large sawtimber), assigned a value consistent with the spacing of interval mid-points to permit quantitative analysis. We calculated the mean for each quantitative variable across the five plots inside and outside each primary diurnal covert and log-transformed earthworm density, earthworm fresh weight, and earthworm dry weight to improve normality.

We conducted principle components analysis using the correlation matrix (Johnson and Wichern, 2007) of the 13 quantitative variables to obtain uncorrelated, linear combinations of these variables. We used analysis of variance (Ott and Longnecker, 2010) to test the main effects of plot location (i.e., inside vs. outside), age, site, and year on each retained principle component, and adjusted for multiple comparisons using the Tukey-Kramer method (Kramer, 1956). We also tested for interactions between plot location and other main effects, but dropped interaction terms that were not significant (i.e., $P>0.05$ ). We verified model assumptions of residual normality using the Shapiro-Wilk test (Shapiro and Wilk, 1965) and by inspecting normal probability plots, and homogeneity of variance by inspecting residual plots. We used multinomial logistic regression (Agresti, 2007) to test the main effects of plot location, age, and year on generalized overstory cover type. We set mixed upland forest as the 
reference category, specified a mixed model by treating bird identity as a random effect, and used the Gauss-Hermite quadrature approximation method to obtain maximum likelihood estimation (SAS, 2011; PROC GLIMMIX). We did not test the main effect of site on generalized overstory cover type because not all cover types were represented at each site and cover type differences were already evident among management areas (see 2.1.) so we were not interested in further quantifying these differences.

Kernel home range and core-use area size were strongly correlated $(r=0.99)$ so we tested for differences in home range size only. Kernel home ranges and core-use areas were often divided into multiple parts as a result of woodcock movement patterns and so we counted the number of home range and core-use area divisions for each bird to help characterize this aspect of second-order selection. The number of home range and core-use area divisions were moderately correlated $(r=0.51)$ so we retained both variables. We log-transformed kernel home range size in order to improve normality and used analysis of variance to test the main effects of age, site, and year on home range size. We adjusted for multiple comparisons, tested for interactions between main effects, and assessed model assumptions as before. We used log-linear regression assuming a Poisson distribution (Agresti, 2007) to test the main effects of age, site, and year on the number of home range and core-use area divisions. We also tested for interactions between main effects, but dropped interactions that were not significant. We adjusted for slight underdispersion in the number of home range divisions, and slight overdispersion in the number of core-use area divisions, using the deviance scale parameter (SAS, 2011; PROC GENMOD). 
We used logistic regression to derive the coefficient values for the exponential form of the $\mathrm{RSF}\left[\mathrm{w}(\mathrm{x})=\exp \left(\beta_{1} \mathrm{x}_{1}+\ldots+\beta_{\mathrm{p}} \mathrm{x}_{\mathrm{p}}\right)\right]$ based on available and used habitat (Manly et al., 2002). Johnson et al. (2006) found this approach to be both theoretically appropriate and quantitatively robust to sample contamination (i.e., available sample containing used and unused resource units) and overlap (i.e., resource units occurring in the available sample and used sample). Contamination of our sample of available habitat was low (6\%) and overlap among our samples of available and used habitat was minimal $(<1 \%)$. Correlations among quantitative variables were weak $(|r|<0.39)$ and variance inflation factors were low $(<1.5)$ so we retained all variables for model building. We generated 15 a priori logistic regression models relating the probability of use by woodcock of forested land to geographic variables and used the informationtheoretic approach based on Akaike's Information Criterion (AIC) and Akaike weights $\left(w_{\mathrm{i}}\right)$ to select the best candidate model (Anderson et al., 2000). We used Raster Calculator (ArcGIS 10.1) to map the relative probability of use by woodcock of forested land in Rhode Island based on the best candidate model and reclassified relative use into five ordinal classes using geometrical interval classification. Johnson et al. (2006) noted that typical methods for assessing logistic regression performance and model fit are not appropriate for use-availability designs and so we used their validation method to evaluate the best candidate model and to assess proportionality of the RSF to true probability of use. We generated a validation dataset by merging composite areas of used woodcock habitat across sites and randomly selecting $10 \%$ of remaining pixels $(n=2,494)$ that were not present in the samples used to build the RSFs. Following Johnson et al. (2006), we determined observed and expected 
numbers of used pixels in the validation dataset within each ordinal class, converted these into proportions, and used linear regression and chi-square goodness-of-fit to assess the relationship between observed and expected proportions.

Lastly, we illustrated how the RSF can be used to 1) identify areas of older second-growth upland forest in Rhode Island, generally 60 - 100-years-old (Butler et al., 2012), where management to create woodcock habitat might be most beneficial, and 2) forecast how certain forest management practices influence relative use by woodcock of the surrounding landscape. For the first illustration, we calculated for each quantitative variable retained in the best candidate model, the maximum value within the composite areas of used woodcock habitat. For those variables that reduced the relative probability of use by woodcock, we considered maximum values to represent tolerances beyond which were less suitable for woodcock. For example, if distance to the nearest upland young forest reduced the relative probability of use by woodcock and the maximum distance within composite areas of used woodcock habitat was $1,000 \mathrm{~m}$, then areas $\leq 1,000 \mathrm{~m}$ from upland young forest were considered more suitable for woodcock while those $>1,000 \mathrm{~m}$ were considered less suitable. We used the maximum value for each of these variables to select older second-growth upland forest that might be most beneficial for woodcock habitat management. For the second illustration, we considered a $4-\mathrm{km}^{2}$ case study area because management of a woodcock habitat mosaic is recommended at this scale (Williamson, 2010). We chose a site in Arcadia where woodcock were known to occur, forest management practices to improve woodcock habitat have previously been implemented, and the estimated relative use by woodcock varied from low to high. We simulated the creation of about 
30 ha of upland young forest patches $(n=7$; range $=2-10$ ha) and 10 ha of herbaceous forest openings ( $n=3$; range $=2-6$ ha) within areas of deciduous, mixed, or coniferous second-growth forest deemed most beneficial for habitat management, and then re-calculated the RSF to illustrate how relative use changed in response to forest cutting. For simplicity, we placed hypothetical management units adjacent to roads (i.e., access points) and $\geq 100 \mathrm{~m}$ from the nearest stream. We ignored other criteria which might influence where forest cutting can occur, but vary from region to region (e.g., state or local ordinances).

\section{Results}

\subsection{Third-order selection}

We identified 46 diurnal coverts during 2011 and 36 diurnal coverts during 2012. During 2011, 15 of 27 woodcock selected $2-3$ diurnal coverts throughout the summer while others selected one diurnal covert. In contrast, during 2012, 14 of 25 woodcock selected one diurnal covert throughout the summer while others selected two diurnal coverts. Diurnal coverts represented small areas of concentrated activity (mean $\pm \mathrm{SE}=$ $0.64 \pm 0.07$ ha; median $=0.43$ ha; range $=0.02-4.22 \mathrm{ha}$ ) and primary diurnal coverts were only marginally larger $($ mean $=0.86 \pm 0.10 \mathrm{ha}$; median $=0.64 \mathrm{ha}$; range $=0.12-$ 4.22 ha).

We retained the first three principle components because their eigenvalues were $>2.0$, whereas all other eigenvalues were $<1.0$. The first three components accounted for $80 \%$ of the total variance. Component 1 , forest overstory, was characterized by greater values of canopy closure, overstory height class, tree density, basal area, medial dbh, and overstory size class; component 2 , food resource, was characterized 
by greater values of earthworm density, earthworm fresh weight, and earthworm dry weight; and component 3 , forest understory, was characterized by greater values of soil moisture content, soil organic matter content, and shrub and sapling density (Table A.1).

Forest overstory component scores were lower inside primary diurnal coverts $\left(\mathrm{F}_{1}=\right.$ 15.18, $P<0.001$; Fig. 1a), and we found no evidence for significant effects of age, site, year, or interactions $(P \geq 0.152)$. Canopy closure was about $7 \%$ lower, and tree density, basal area, and medial dbh were $21-29 \%$ lower inside primary diurnal coverts (Table 2). Overstory height class was within the $3-9 \mathrm{~m}$ interval inside primary diurnal coverts while height class was $>9 \mathrm{~m}$ outside primary diurnal coverts. Overstory size class was within the $11.5-26.7 \mathrm{~cm}$ (i.e., pole) interval inside and outside primary diurnal coverts, but overstory trees outside primary diurnal coverts tended towards the $26.8-41.9 \mathrm{~cm}$ (i.e., small sawtimber) interval (Table 2).

Food resource component scores were similar at Arcadia and Big River, but greater at Great Swamp $\left(\mathrm{F}_{2}=6.87, P=0.002\right)$, and were greater inside primary diurnal coverts $\left(\mathrm{F}_{1}=5.97, P=0.009\right.$; Fig. $\left.1 \mathrm{~b}\right)$. We found no evidence for significant effects of age, year, or interactions $(P \geq 0.063)$. Non-transformed earthworm density $($ mean \pm SE) was $20-24 \%$ greater at Great Swamp $(18.70 \pm 4.56)$ than Arcadia $(14.89 \pm 4.68)$ or Big River $(14.14 \pm 3.91)$ while earthworm fresh weight was 48 $62 \%$ greater at Great Swamp (10.91 \pm 4.41$)$ than Arcadia $(5.63 \pm 1.87)$ or Big River $(4.18 \pm 1.21)$. Earthworm dry weight was $39-51 \%$ greater at Great Swamp $(2.10 \pm$ $0.80)$ than Arcadia (1.28 \pm 0.41$)$ or Big River (1.02 \pm 0.30$)$. Irrespective of site, 
earthworm density, earthworm fresh weight, and earthworm dry weight were 46 67\% greater inside primary diurnal coverts (Table 2).

Forest understory component scores were also similar at Arcadia and Big River, but greater at Great Swamp $\left(\mathrm{F}_{2}=14.02, P<0.001\right)$, and were greater inside primary diurnal coverts $\left(F_{1}=3.24, P=0.038\right.$; Fig. $\left.1 \mathrm{c}\right)$. We found no evidence for significant effects of age, year, or interactions $(P \geq 0.220)$. Soil moisture content (mean $\pm \mathrm{SE})$ was $30-51 \%$ greater at Great Swamp (57.56 \pm 3.98$)$ than Arcadia $(40.35 \pm 2.84)$ or Big River $(27.96 \pm 2.51)$ and soil organic matter content was $37-51 \%$ greater at Great Swamp (40.57 \pm 3.72$)$ than Arcadia $(25.76 \pm 3.35)$ or Big River $(19.81 \pm 2.67)$. Shrub and sapling density was $44-52 \%$ greater at Great Swamp $(25,000.00 \pm$ $2,821.69)$ than Arcadia $(12,033.33 \pm 2,419.62)$ or Big River $(14,083.33 \pm 2,699.20)$. Regardless of site, soil moisture content and soil organic matter content were similar inside and outside primary diurnal coverts whereas shrub and sapling density was $46 \%$ greater inside primary diurnal coverts (Table 2).

Generalized overstory cover type differed by plot location $\left(\mathrm{F}_{4,248}=4.58, P=\right.$ $0.001)$, but we found no evidence for significant effects of age or year $(P \geq 0.124)$. Relative to mixed upland forest, the odds of occurring inside primary diurnal coverts were similar for deciduous upland forest (odds ratio $=1.26,95 \% \mathrm{CI}=0.68-2.34$ ), wetland forest (odds ratio $=1.61,95 \% \mathrm{CI}=0.80-3.21$ ), and herbaceous cover types (odds ratio $=0.52,95 \% \mathrm{CI}=0.14-1.90$ ). In contrast, relative to mixed upland forest, coniferous upland forest was less likely to occur inside primary diurnal coverts (odds ratio $=0.16,95 \% \mathrm{CI}=0.06-0.44)$. 


\subsection{Second-order selection}

We found no evidence for significant effects of age, site, year, or interactions on kernel home range size $(P \geq 0.091)$. Non-transformed kernel home range size varied from $1.04-474.52$ ha with a mean \pm SE of $51.13 \pm 13.81$ ha and median of 11.29 ha. Core-use areas varied from $0.19-75.49$ ha with a mean of $8.45 \pm 2.21$ ha and median of 2.03 ha. Minimum convex polygon home ranges varied from $0.43-487.01$ ha with a mean of $57.55 \pm 12.52$ ha and median of 19.24 ha. The number of kernel home range divisions differed by age $\left(\mathrm{F}_{1,47}=5.15, P=0.023\right)$, but we found no evidence for significant effects of site, year, or interactions $(P \geq 0.065)$. The home ranges of aftersecond-year males were divided into $1.59(95 \% \mathrm{CI}=1.06-2.41)$ times more parts than the home ranges of second-year males. We found no evidence for significant effects of age, site, year, or interactions on the number of core-use area divisions $(P \geq$ $0.246)$.

Of the 15 a priori logistic regression models that we tested (Table A.2), the topranked model produced the lowest AIC and accounted for $94 \%$ of the Akaike weight. This model suggested that the relative probability of use by woodcock 1) increased with increasing elevation, 2) decreased with increasing slope, 3) was higher in deciduous upland forest, mixed upland forest, deciduous wetland forest, mixed wetland forest, and wetland young forest, but lower in coniferous upland forest, upland young forest, and coniferous wetland forest, and 4) decreased with increasing distance to the nearest stream, agricultural opening, upland young forest, and moist soil (Table 3). The vast majority of forested land in Rhode Island occurred in the low $\left(445 \mathrm{~km}^{2}\right)$, low-moderate $\left(234 \mathrm{~km}^{2}\right)$, moderate $\left(533 \mathrm{~km}^{2}\right)$, and moderate-high (444 
$\left.\mathrm{km}^{2}\right)$ classes of relative use whereas areas of high relative use $\left(46 \mathrm{~km}^{2}\right)$ were widely scattered (Fig. 2a). Our validation of the RSF revealed adequate fit between observed and expected proportions of pixels in each ordinal class $\left(\mathrm{X}_{4}^{2}=0.083, P=0.999\right)$. In addition, the linear regression model relating observed and expected proportions of pixels in each ordinal class $(y=0.921 \mathrm{x}+0.016)$ had an intercept similar to $0(P=$ $0.718)$, a slope $>0(P=0.011)$, but near 1 , and a high $\mathrm{R}^{2}(0.912)$ indicating that the RSF was proportional to true probability of use.

\subsection{Applications of the resource selection function}

Older second-growth upland forest (e.g., 60 - 100 years) in Rhode Island where woodcock habitat management was deemed most beneficial was within the maximum values of used woodcock habitat (i.e., composite core-use areas; see 2.3.2.) for each quantitative variable that reduced relative probability of use in the top-ranked RSF. Generally, management of older second-growth upland forest was deemed most beneficial on slopes $\leq 53 \%$ and within $1,211 \mathrm{~m}$ of the nearest stream, 1,314 $\mathrm{m}$ of the nearest agricultural opening, 1,498 $\mathrm{m}$ of the nearest upland young forest, and $639 \mathrm{~m}$ of the nearest moist soil. Most $\left(1,281 \mathrm{~km}^{2}\right)$ older second-growth upland forest was located in areas where woodcock habitat management was classified as most beneficial while only $109 \mathrm{~km}^{2}$ was located in areas where management was classified as least beneficial (Fig. 2b). Across the $4-\mathrm{km}^{2}$ case study area, clearcutting 40 ha (10\%) to produce young forest and forest openings reduced the 210 ha of forested land in the low class of relative use to 118 ha, increased the 77 ha in both the low-moderate and moderate classes of relative use to 103 ha and 115 ha, respectively, and increased the 22 ha in the moderate-high class of relative use to 38 ha (Fig. 3). 


\section{Discussion}

\subsection{Third-order selection}

We found that daytime activity by male woodcock in Rhode Island was highly localized within areas of their home range. In Pennsylvania, USA, the diurnal coverts of male woodcock during April - May were about 0.1 - 1.0 ha (Hudgins et al., 1985). Most (74\%) of the diurnal coverts that we identified were within this range, but some were as much as four times larger. Adult females caring for young concentrated daytime activity within areas that were approximately $0.8-2.6$ ha in Minnesota, USA (Wenstrom, 1974), and $1.0-2.8$ ha in Pennsylvania (Caldwell and Lindzey, 1974) so localized habitat selection is not specific to males. Localized habitat selection has also been found during winter months in Alabama, USA, where woodcock activity centers were from $0.4-5.7$ ha (Horton and Causey, 1979). Historically, young forest likely occurred as relatively small, isolated patches resulting from localized natural disturbances (Askins, 2001) so woodcock and other young forest birds likely adapted to exploit small areas of preferred habitat (Askins et al., 2007).

The structure of preferred young forest provides woodcock protection from predators (Dessecker and McAuley, 2001; Keppie and Whiting, 1994; McAuley et al., 1996; Straw et al., 1986), but older forest might also be selected for nesting, broodrearing, or feeding if the density of shrub or sapling stems is sufficient to provide similar protective cover (Dessecker and McAuley, 2001; Williamson, 2010). On average, tree density inside the primary diurnal coverts that we investigated was about 466 stems/ha which was less than the tree density associated with aspen (Populus spp.; mean $=760$ stems $/$ ha $)$ and mixed deciduous forest types $($ mean $=890$ stems $/$ ha $)$ 
selected by woodcock in Michigan, USA (Rabe, 1977), but similar to the tree density associated with nesting and brood-rearing habitat selected by female woodcock (range $=400-783$ stems/ha; Dessecker and McAuley, 2001). In Pennsylvania, optimum basal area of trees and sapling density for daytime habitat was estimated to be 14.3 $\mathrm{m}^{2} /$ ha and 4,900 stems/ha, respectively, and woodcock generally avoided areas where basal area was $\geq 20.0 \mathrm{~m}^{2} /$ ha and sapling density was $<1,500$ stems/ha (Straw et al., 1986). We found that mean basal area inside primary diurnal coverts was $22.1 \mathrm{~m}^{2} / \mathrm{ha}$ and shrub and sapling density was 21,452 stems/ha. While overstory trees inside primary diurnal coverts tended to be shorter and smaller in diameter (i.e., younger) than those outside (Table 2), woodcock in Rhode Island may currently be selecting the best available forest rather than optimum forest.

The high shrub and sapling density typical of diurnal coverts in Rhode Island may protect woodcock from predators even though the structure of selected coverts differs from young forests that woodcock typically select in other areas of the Northeast. Indeed, in some areas, understory structure rather than species composition may be most useful for identifying sites selected by woodcock (Rabe, 1977). The shrub and sapling density that we observed inside primary diurnal coverts was over four times greater than the sapling density at sites selected by woodcock in Pennsylvania (Straw et al., 1986) and similar to shrub and sapling densities in areas selected by female woodcock in Minnesota (Morgenweck, 1977) and Maine, USA (McAuley et al., 1996). Moreover, shrub and sapling density was nearly two times greater inside than outside primary diurnal coverts. We only documented eight mortalities among the 60 woodcock that we monitored during summers 2011 and 2012 so woodcock survival is 
relatively high in Rhode Island. Woodcock survival is also relatively high in Maine (Derleth and Sepik, 1990) where optimum habitat is more widespread. Thus, the shrub and sapling density typical of diurnal coverts in Rhode Island apparently provides similar protective cover as forests selected by woodcock in other parts of the Northeast.

Woodcock typically feed in forested coverts during the day (Masse et al., 2013) and so our findings that woodcock consistently selected forest stands where earthworm availability was at least $46 \%$ greater than random sites (Table 2) help support this conclusion. On average, earthworm dry weight at heavily-used diurnal coverts in Maine was $18.2 \mathrm{~g} / \mathrm{m}^{2}$ compared to 15.4 and $7.8 \mathrm{~g} / \mathrm{m}^{2}$ at commonly- and rarely-used diurnal coverts, respectively (Reynolds et al., 1977). During summer, greater earthworm density or biomass at sites selected by woodcock has also been reported in Pennsylvania (mean $=34.4$ earthworms $/ \mathrm{m}^{2}$; Hudgins et al., 1985) and Minnesota (range $=4.4-23.0 \mathrm{~g} / \mathrm{m}^{2} ;$ Morgenweck, 1977). In contrast, Sepik and Derleth (1993) found no relationship between earthworm dry weight and woodcock habitat selection in Maine, but noted that mean earthworm dry weight was $8.9 \mathrm{~g} / \mathrm{m}^{2}$ at sites selected by woodcock. Mean earthworm density $\left(23.7\right.$ earthworms $\left./ \mathrm{m}^{2}\right)$ and dry weight $\left(1.8 \mathrm{~g} / \mathrm{m}^{2}\right)$ inside primary diurnal coverts in Rhode Island were generally lower than those found elsewhere in the Northeast. However, earthworm availability was even more limited outside primary diurnal coverts (Table 2) suggesting that woodcock selected areas that could maximize feeding opportunities. 


\subsection{Second-order selection}

We found that the size of kernel home ranges and core-use areas for male woodcock in Rhode Island were highly variable, but did not differ by age, site, or year. Historically, MCPs have been the standard method used to estimate woodcock home ranges, but the shortcomings of this method have prompted researchers to advocate kernel methods for contemporary studies (Powell, 2000). Yet, MCPs may still be a valid and favored method for delineating areas used by certain taxa (e.g., herpetofauna; Row and Blouin-Demers, 2006) or under certain situations (e.g., our delineation of primary diurnal coverts). During summer, mean diurnal home range size (MCP) for adult (19 ha) and juvenile (13 ha) male woodcock in Maine did not differ (Sepik and Derleth, 1993) which coincides with our conclusion using kernel methods. The mean home range sizes that we observed for woodcock in Rhode Island using either kernel or MCP methods were considerably larger than mean MCP home range estimates for woodcock in Maine (8 - 19 ha depending on cohort; Sepik and Derleth, 1993) and Alabama (9.2 ha; Horton and Causey, 1979). However, the median home range sizes that we observed were similar to those found in Pennsylvania (median $=$ 3.1 - 73.6 ha depending on activity level; Hudgins et al., 1985) and more similar to mean home range sizes reported elsewhere. The unusually large home ranges that we observed for some woodcock (e.g., 474.5 ha) inflated our estimates of mean home range size and are clearly not typical of most woodcock in Rhode Island as $73 \%$ and $67 \%$ of kernel and MCP home ranges, respectively, were $<50$ ha.

Adult male woodcock have been found to move greater distances between successive daytime locations than juvenile males (Sepik and Derleth, 1993) so this 
could partially explain why the number of home range divisions was greater for the older cohort in our study. Animal memory is likely an important factor influencing home range use patterns (Van Moorter et al., 2009) and the diurnal home ranges of more experienced (i.e., older) woodcock might be divided into more parts if these birds tend to re-visit familiar sites on the landscape in order to exploit resources which could vary spatially or temporally (e.g., earthworms; Reynolds et al., 1977). For example, the one woodcock that we were able to monitor during subsequent summers was a second-year during 2011 and an after-second-year during 2012. During 2011, his diurnal home range was divided into two parts which were separated by about 146 m whereas his home range during 2012 was divided into four parts which, on average, were separated by about $973 \mathrm{~m}$ (range $=137-1,628 \mathrm{~m}$ ). Importantly, this male showed some capacity to re-visit sites used in previous years while also exploiting apparently new areas on the surrounding landscape since one of the four divisions of his 2012 home range overlapped with one of the divisions of his 2011 home range.

All else being equal, relative use by woodcock of forested land tended to be greatest in wetland forest and lowest in coniferous upland forest (Table 3). Wetland forest may be particularly attractive to woodcock as daytime habitat during summer because the moist soils typically associated with this cover type tend to promote higher densities of earthworms and shrub or sapling stems (Williamson, 2010). The fact that relative use was most negatively influenced by coniferous upland forest coincides with our finding that this cover type was less likely to occur inside primary diurnal coverts. Consequently, relative use by woodcock can effectively be increased if older, second-growth, coniferous upland forests are harvested and replaced with 
upland young forest, or deciduous or mixed upland forest. However, coniferous upland forest may be selected by woodcock during periods of summer drought (Sepik et al., 1983) so some of this forest type should be maintained on landscapes within or around woodcock habitat mosaics.

We also found that relative use by woodcock of forested land decreased at higher slopes and farther distances from the nearest stream, moist soil, upland young forest, and agricultural opening. Woodcock habitat suitability also declined on steeper slopes in West Virginia, USA (Steketee, 2000). In general, woodcock habitat management is considered most beneficial on flatter slopes (Dessecker and McAuley, 2001) perhaps because these areas can better support earthworm populations (Steketee, 2000). Our findings that proximity to streams and moist soils influences relative use supports the views that creating woodcock habitat closer to streams (Williamson, 2010) or across moisture gradients (Dessecker and McAuley, 2001) is most beneficial. The affinity of woodcock to young forest has been well-documented across the Northeast (Hudgins et al., 1985; McAuley et al., 1996; Sheldon, 1967) and so we expected relative use to decrease as distance to the nearest upland young forest increased. However, we were somewhat surprised to find that relative use also decreased as distance to the nearest agricultural opening increased because greater proportions of agriculture on the surrounding landscape reduced woodcock habitat suitability in West Virginia (Steketee, 2000) and were not associated with areas used by woodcock during spring in Pennsylvania (Klute et al., 2000). Variation in the response of woodcock populations to agricultural openings likely relates to the predominant type of agriculture in a region or considered in a given study, but this subject has yet to be 
investigated. Some agricultural openings provide critical breeding sites for woodcock during spring (Sheldon, 1967) and roosting sites during summer (Dunford and Owen, 1973; Masse et al., 2013) so the proximity of these landscape features to forests used by woodcock has some ecological relevance. Declines of woodcock populations in Pennsylvania from the 1960's - 1970's mirrored declines in the extent of pastureland and other cover types used by woodcock (Gutzwiller et al., 1980) so it seems reasonable that forests farther from certain agricultural openings are generally less ideal than those closer to these forest openings.

\subsection{Applications of the resource selection function}

Given the link between declines of woodcock populations and young forest, the American Woodcock Conservation Plan (AWCP) established habitat goals for restoring woodcock densities to those of the 1970's (Kelley et al., 2008). Across the Northeast, $>22,000 \mathrm{~km}^{2}$ of young forest is needed to restore woodcock densities (Kelley et al., 2008) so widespread, active forest management will be required if the goals of the AWCP are to be met. Forest clearcutting is generally regarded as the most efficient method for creating quality woodcock habitat (Dessecker and McAuley, 2001; McAuley et al., 1996; Williamson, 2010). On the one hand, non-game birds which require similar young forest would likely benefit from woodcock habitat management. On the other hand, removing all trees from select areas may be aesthetically displeasing (Gobster, 2001) or viewed as harmful to populations of wildlife that require more mature forest (Wallendorf et al., 2007). Consequently, forest management efforts to create quality woodcock habitat should be strategically- 
coordinated and scientifically-informed so that conservation benefits are maximized while negative impacts are minimized.

Managing young forest to increase relative probability of use by woodcock of surrounding landscapes can help improve connectivity between habitat patches thereby reducing the negative impacts of habitat patch isolation. Moderate-high and high classes of relative use were widely scattered across Rhode Island (Fig. 2a) and metapopulation theory dictates that immigration to habitat patches decreases as isolation of habitat patches increases (Hanski, 1998). We used our RSF to identify $1,281 \mathrm{~km}^{2}$ of older second-growth upland forest where habitat management might be most beneficial for increasing relative use by woodcock (Fig. 2b). About $377 \mathrm{~km}^{2}$ of young forest must be managed in Rhode Island to restore woodcock population densities (Kelley et al., 2008), but this represents roughly $14 \%$ of the total land area and is about four times larger than the current extent of young forest in the state (Buffum et al., 2011). A more feasible goal might be to first stabilize the extent of non-coastal upland young forest by clearcutting about 136 ha of older second-growth forest per year over the next 20 years (Buffum et al., 2011). We recommend that forest clearcutting to create habitat for woodcock and other young forest wildlife (e.g., New England cottontail [Sylvilagus transitionalis]) should take place in areas identified as most beneficial for management in order to help meet the goals of the AWCP. In addition, other land management practices such as allowing $\geq 30$-m buffers around agricultural openings to regenerate into young forest benefit woodcock (Williamson, 2010) and increase the extent of young forest without requiring older forest to be cut down. 
In the Northeast, woodcock best management practices focus on creating habitat mosaics that provide all necessary components of quality habitat within a $4-\mathrm{km}^{2}$ landscape (Williamson, 2010). About $25 \%$ of each habitat mosaic should be maintained as young forest by clearcutting blocks $>2$ ha on a 40 -year rotation (McAuley et al., 1996), and occasional herbaceous forest openings (e.g., wildlife openings or old fields) should be maintained to provide breeding sites (e.g., $>0.2$ ha each; about eight per 40 ha) and roosting sites (e.g., >2 ha each; about one per 40 ha; Williamson, 2010). Clearcutting forest blocks $>1$ ha has also been recommended to conserve other species of young forest birds (Schlossberg and King, 2007). Moreover, wildlife openings such as old fields provide adequate habitat for some of these species (King et al., 2009). We used our RSF to show that creating 30 ha of upland young forest and 10 ha of herbaceous forest openings at key sites in a $4-\mathrm{km}^{2}$ case study area increased relative use by woodcock of surrounding forested land (Fig. 3).

Clearcutting older second-growth upland forest to enhance woodcock habitat is not suitable in all areas so tools that can distinguish where management efforts are likely to be most effective will be useful in forest management decision-making. The RSF that we developed represents such a tool for biologists managing woodcock habitat across Rhode Island or similar landscapes in the Northeast. Geographic data sets can be easily manipulated allowing biologists to simulate competing forest management plans, forecast the response of target woodcock populations using our RSF, and then select the management plan that produces the greatest increase in relative probability of use. Resource selection functions can accommodate various study designs and data collection methods (Manly et al. 2002) so biologists in other regions can develop their 
own RSFs provided they have basic data on used and available or unused sites. Employing quantitative tools such as RSFs during the decision-making process will help to maximize conservation benefits and facilitate more efficient and effective forest management planning.

\section{Acknowledgments}

Funding for this project was provided by the following sources: Rhode Island Agricultural Experiment Station, the US Department of Agriculture McIntyre-Stennis (MS-975) and Hatch (H-333) grants, the Rhode Island Department of Environmental Management via USFWS Federal Aid to Wildlife Investigations Project W-23R, and the Department of Natural Resources Science at University of Rhode Island. Many volunteers assisted with woodcock captures and we thank them for their help. We also thank T. Heywood, S. Camillieri, J. Veale, J. Travers, A. Hunt, A. Padula, W. Shean, L. Barnard, D. Duffin, and D. McAuley for their help in the field. Finally, we thank A. Smith and L. Gonzalez for statistical advice, and the two anonymous reviewers that provided helpful comments on an earlier version of this manuscript. This is contribution number XXXX of the Rhode Island Agricultural Experiment Station.

\section{Appendix A. Supplementary material}

Supplementary data associated with this article can be found, in the online version, at XXXX.

\section{References}

Agresti, A., 2007. An Introduction to Categorical Data Analysis, Second Edition. John Wiley and Sons, Hoboken, New Jersey. 
Anderson, D.R., Burnham, K.P., Thompson, W.L., 2000. Null hypothesis testing: problems, prevalence, and an alternative. J. Wildlife Manage. 64, 912-923.

Askins, R.A., 2001. Sustaining biological diversity in early successional communities: the challenge of managing unpopular habitats. Wildlife Soc. B. 29, 407-412.

Askins, R.A., Zuckerberg, B., Novak, L., 2007. Do the size and landscape context of forest openings influence the abundance and breeding success of shrubland songbirds in southern New England? For. Ecol. Manage. 250, 137-147.

Beyer, H.L., 2013. Geospatial Modelling Environment. Spatial Ecology, LLC. Accessed 19 October 2013. Available from: $<$ http://www.spatialecology.com/gme/>.

Blackman, E.B., Deperno, C.S., Heiniger, R.W., Krachey, M.J., Moorman, C.E., Peterson, M.N., 2012. Effects of crop field characteristics on nocturnal winter use by American woodcock. J. Wildlife Manage. 76, 528-533.

Brown, G.S., Rettie, W.J., Brooks, R.J., Mallory, F.F., 2007. Predicting the impacts of forest management on woodland caribou habitat suitability in black spruce boreal forest. For. Ecol. Manage. 245, 137-147.

Buffum, B., McWilliams, S.R., August, P.V., 2011. A spatial analysis of forest management and its contribution to maintaining the extent of shrubland habitat in southern New England, United States. For. Ecol. Manage. 262, 1775-1785.

Butler, B.J., Morin, R.S., Nelson, M.D., 2012. Rhode Island's Forest Resources, 2011. Research Note NRS-151, US Department of Agriculture, Forest Service, Northern Research Station. Newtown Square, Pennsylvania. Accessed 13 December 2013. Available from: 
$<$ http://www.nrs.fs.fed.us/pubs/rn/rn_nrs151.pdf $>$.

Caldwell, P.D., Lindzey, J.S., 1974. The behavior of adult female woodcock in central Pennsylvania. Proceedings of the Fifth American Woodcock Workshop; 3 - 5 December 1974; Athens, Georgia. US Fish and Wildlife Service. Washington, DC, pp. 178-192.

Connors, J.I., Doerr, P.D., 1982. Woodcock use of agricultural fields in coastal North Carolina. Woodcock Ecology and Management: Papers from the Seventh Woodcock Symposium; 28 - 30 October 1980; University Park, Pennsylvania. US Fish and Wildlife Service, Wildlife Research Report 14. Washington, DC, pp. 139-147.

Cooper, T.R., Rau, R.D., 2012. American Woodcock Population Status, 2012. U.S. Fish and Wildlife Service, Laurel, Maryland.

Dangerfield, J.M., 1997. Abundance and diversity of soil macrofauna in northern Botswana. J. Trop. Ecol. 13, 527-538.

Day, G.M., 1953. The Indian as an ecological factor in the northeastern forest. Ecology 34, 329-346.

DeGraaf, R.M., Yamasaki, M., 2003. Options for managing early-successional forest and shrubland bird habitats in the northeastern United States. For. Ecol. Manage. $185,179-191$.

Derleth, E.L., Sepik, G.F., 1990. Summer-fall survival of American woodcock in Maine. J. Wildlife Manage. 54, 97-106.

Dessecker, D.R., McAuley, D.G., 2001. Importance of early successional habitat to ruffed grouse and American woodcock. Wildlife Soc. B. 29, 456-465. 
Dettmers, R., 2003. Status and conservation of shrubland birds in the northeastern US. For. Ecol. Manage. 185, 81-93.

Dunford, R.D., Owen Jr., R.B., 1973. Summer behavior of immature radio-equipped woodcock in central Maine. J. Wildlife Manage. 37, 462-469.

Enser, R.W., Lundgren, J.A., 2006. Natural communities of Rhode Island. Rhode Island Natural History Survey, Kingston, Rhode Island. Accessed 19 October 2013. Available from: <http://rinhs.org/wpcontent/uploads/2012/05/ri_nat_comms_2006.pdf>.

Foster, D.R., Aber, J.D., 2004. Forests in Time: the Environmental Consequences of 1,000 years of Change in New England. Yale University Press, New Haven, Connecticut.

Foster, D.R., Motzkin, G., Slater, B., 1998. Land-use history as long-term broad-scale disturbance: regional forest dynamics in central New England. Ecosystems 1, 96119.

Gesch, D., Oimoen, M., Greenlee, S., Nelson, C., Steuck, M., Tyler, D., 2002. The national elevation dataset. Photogramm. Eng. Rem. S. 68, 5-11.

Gobster, P.H., 2001. Human dimensions of early successional landscapes in the eastern United States. Wildlife Soc. B. 29, 474-482.

Gutzwiller, K.J., Strauss, C.H., Kinsley, K.R., Wakeley, J.S., Storm, G.L., 1980. Relationships between land use and woodcock habitat in Pennsylvania, with guidelines for rangewide research. Woodcock Ecology and Management: Papers from the Seventh Woodcock Symposium; 28 - 30 October 1980; University Park, 
Pennsylvania. US Fish and Wildlife Service, Wildlife Research Report 14.

Washington, DC, pp. 86-96.

Hackett, H.M., Pagels, J.F., 2003. Nest site characteristics of the endangered northern flying squirrel (Glaucomys sabrinus coloratus) in southwest Virginia. Am. Midl. Nat. 150, 321-331.

Hanski, I., 1998. Metapopulation dynamics. Nature 396, 41 - 49.

Horne, J.S., Garton, E.O., 2006. Likelihood cross-validation versus least squares cross-validation for choosing the smoothing parameter in kernel home-range analysis. J. Wildlife Manage. 70, 641-648.

Horton, G.I., Causey, M.K., 1979. Woodcock movements and habitat utilization in central Alabama. J. Wildlife Manage. 43, 414-420.

Hudgins, J.E., Storm, G.L., Wakeley, J.S., 1985. Local movements and diurnal-habitat selection by male American woodcock in Pennsylvania. J. Wildlife Manage. 49, $614-619$.

Johnson, C.J., Nielsen, S.E., Merrill, E.H., McDonald, T.L., Boyce, M.S., 2006. Resource selection functions based on use-availability data: theoretical motivation and evaluation methods. J. Wildlife Manage. 70, 347-357.

Johnson, C.J., Seip, D.R., Boyce, M.S., 2004. A quantitative approach to conservation planning: using resource selection functions to map the distribution of mountain caribou at multiple spatial scales. J. Appl. Ecol. 41, 238-251.

Johnson, D.H., 1980. The comparison of usage and availability measurements for evaluating resource preference. Ecology 61, 65-71. 
Johnson, R.A., Wichern, D.W., 2007. Applied Multivariate Statistical Analysis, Sixth Edition. Pearson Prentice Hall, Upper Saddle River, New Jersey.

Kelley, J., Williamson, S., Cooper, T.R. (Eds.), 2008. American Woodcock Conservation Plan: A Summary of and Recommendations for Woodcock Conservation in North America. Wildlife Management Institute. Accessed 19 October 2013. Available from: <http://timberdoodle.org/sites/default/files/woodcockPlan_0.pdf>.

Keppie, D.M., Whiting Jr., R.M., 1994. American woodcock (Scolopax minor), in: Poole, A (Ed.), The Birds of North America. Cornell Lab of Ornithology, Ithaca, New York.

King, D.I., Chandler, R.B., Schlossberg, S., Chandler, C.C., 2009. Habitat use and nest success of scrub-shrub birds in wildlife and silvicultural openings in western Massachusetts, USA. For. Ecol. Manage. 257, 421-426.

Klute, D.S., Lovallo, M.J., Tzilkowski, W.M., Storm, G.L., 2000. Determining multiscale habitat and landscape associations for American woodcock in Pennsylvania. Proceedings of the Ninth American Woodcock Symposium; 26 - 28 January 1997; Baton Rouge, Louisiana. US Geological Survey, Biological Resources Division Information and Technology Report USGS/BRD/ITR-20000009. Washington, DC, pp. 42-49.

Kramer, C.Y., 1956. Extension of multiple range tests to group means with unequal numbers of replications. Biometrics 12, 307-310.

Krohn, W.B., Rieffenberger, J.C., Ferrigno, F., 1977. Fall migration of woodcock at Cape May, New Jersey. J. Wildlife Manage. 41, 104-111. 
Lemmon, P.E., 1957. A new instrument for measuring forest overstory density. J. For. $55,667-669$.

Lorimer, C.G., 2001. Historical and ecological roles of disturbance in eastern North American forests: 9,000 years of change. Wildlife Soc. B. 29, 425-439.

Manly, B.F.J., McDonald, L.L., Thomas, D.L., McDonald, T.L., Erickson, W.P., 2002. Resource Selection by Animals: Statistical Design and Analysis for Field Studies, Second Edition. Kluwer Academic Publishers, Dordrecht, Netherlands.

Masse, R.J., Tefft, B.C., Amador, J.A., McWilliams, S.R., 2013. Why woodcock commute: testing the foraging-benefit and predation-risk hypotheses. Behav. Ecol. $24,1348-1355$.

McAuley, D.G., Longcore, J.R., Clugston, D.A., Allen, R.B., Weik, A., Williamson, S., Dunn, J., Palmer, B., Evans, K., Staats, W., Sepik, G.F., Halteman, W., 2005. Effects of hunting on survival of American woodcock in the Northeast. J. Wildlife Manage. 69, 1565-1577.

McAuley, D.G., Longcore, J.R., Sepik, G.F., 1993. Techniques for research into woodcock: experiences and recommendations. Proceedings of the Eighth American Woodcock Symposium; 29 October - 2 November 1990; West Lafayette, Indiana. US Fish and Wildlife Service, Biological Report 16. Washington, DC, pp. 5-11.

McAuley, D.G., Longcore, J.R., Sepik, G.F., Pendleton, G.W., 1996. Habitat characteristics of American woodcock nest sites on a managed area in Maine. J. Wildlife Manage. 60, 138-148. 
McDonald, T.L., 2013. The point process use-availability or presence-only likelihood and comments on analysis. J. Anim. Ecol. 82, 1174-1182.

Miller, H.E., Jordan, M.J., 2011. Relationship between exotic invasive shrubs and American woodcock (Scolopax minor) next success and habitat selection. J. PA Acad. Sci. 85, 132-139.

Mohr, C.O., 1947. Table of equivalent populations of North American small mammals. Am. Midl. Nat. 37, 223-249.

Morgenweck, R.O., 1977. Diurnal high use areas of hatching-year female American woodcock. Proceedings of the Sixth Woodcock Symposium; 4 - 6 October 1977; Fredericton, New Brunswick. US Fish and Wildlife Service. Washington, DC, pp. $155-160$.

O’Keefe, J.M., Loeb, S.C., Lanham, J.D., Hill Jr., H.S., 2009. Macrohabitat factors affect day roost selection by eastern red bats and eastern pipistrelles in the southern Appalachian Mountains, USA. For. Ecol. Manage. 257, 1757-1763.

Ott, R.L., Longnecker, M., 2010. An Introduction to Statistical Methods and Data Analysis, Sixth Edition. Brooks/Cole, Belmont, California.

Powell, R.A., 2000. Animal home ranges and territories and home range estimators, in: Boitani, L., Fuller, T.K. (Eds.), Research Techniques in Animal Ecology: Controversies and Consequences. Columbia University Press, New York, New York, pp. 65-110.

Rabe, D., 1977. Structural analysis of woodcock diurnal habitat in northern Michigan. Proceedings of the Sixth Woodcock Symposium; 4 - 6 October 1977; Fredericton, New Brunswick. US Fish and Wildlife Service. Washington, DC, pp. 125-134. 
Reynolds, J.W., Krohn, W.B., Jordan, G.A., 1977. Earthworm populations as related to woodcock habitat usage in central Maine. Proceedings of the Sixth Woodcock Symposium; 4 - 6 October 1977; Fredericton, New Brunswick. US Fish and Wildlife Service. Washington, DC, pp. 135-146.

RIGIS, 2001. Freshwater Rivers and Streams. Rhode Island Geographic Information Systems Data Distribution System, Environmental Data Center. University of Rhode Island, Kingston. Accessed 21 October 2013. Available from: $<$ http://www.edc.uri.edu/rigis $>$.

RIGIS, 2012. Forest Habitat. Rhode Island Geographic Information System Data Distribution System, Environmental Data Center. University of Rhode Island, Kingston. Accessed 21 October 2013. Available from: $<$ http://www.edc.uri.edu/rigis $>$.

RIGIS, 2013. Soil Survey Geographic (SSURGO) Soil Polygons. Rhode Island Geographic Information System Data Distribution System, Environmental Data Center. University of Rhode Island, Kingston. Accessed 28 October 2013. Available from: <http://www.edc.uri.edu/rigis $>$.

Row, J.R., Blouin-Demers, G., 2006. Kernels are not accurate estimators of homerange size for herpetofauna. Copeia 4, 797-802.

SAS, 2011. SAS/STAT 9.3 User's Guide. SAS Institute, Inc., Cary, North Carolina. Accessed 21 October 2013. Available from: $<$ http://support.sas.com/documentation/>. 
Schlossberg, S., King, D.I., 2007. Ecology and Management of Scrub-shrub Birds in New England: A Comprehensive Review. Natural Resources Conservation Service, Resource Inventory and Assessment Division, Beltsville, Maryland.

Seaman, D.E., Millspaugh, J.J., Kernohan, B.J., Brundige, G.C., Raedeke, K.J., Gitzen, R.A., 1999. Effects of sample size on kernel home range estimates. J. Wildlife Manage. 63, 739-747.

Sepik, G.F., Derleth, E.L., 1993. Habitat use, home range size, and patterns of moves of the American woodcock in Maine. Proceedings of the Eighth American Woodcock Symposium; 29 October - 2 November 1990; West Lafayette, Indiana. US Fish and Wildlife Service, Biological Report 16. Washington, DC, pp. 41-49. Sepik, G.F., Owen Jr., R.B., Dwyer, T.J., 1983. The effect of drought on a local woodcock population. Trans. Northeast Sec. Wildlife Soc. 40, 1-8.

Shapiro, S.S., Wilk, M.B., 1965. An analysis of variance test for normality (complete samples). Biometrika 52, $591-611$.

Sheldon, W.G., 1967. The Book of the American Woodcock. University of Massachusetts, Amherst.

Steketee, A.K., 2000. Predicting Habitat Suitability for American Woodcock and Landscape-level Assessment of Habitat in West Virginia. PhD Dissertation, West Virginia University, Morgantown.

Straw Jr., J.A., Wakeley, J.S., Hudgins, J.E., 1986. A model for management of diurnal habitat for American woodcock in Pennsylvania. J. Wildlife Manage. 50, $378-383$. 
Trani, M.K., Brooks, R.T., Schmidt, T.L., Rudis, V.A., Gabbard, C.M., 2001. Patterns and trends of early successional forests in the eastern United States. Wildlife Soc. B. $29,413-424$.

Twery, M.J., Knopp, P.D., Thomasma, S.A., Nute, D.E., 2011. NED-2 User’s Guide. General Technical Report NRS-85. US Department of Agriculture, Forest Service, Northern Research Station. Newtown Square, Pennsylvania. Accessed 19 October 2013. Available from: <http://www.nrs.fs.fed.us/pubs/39537>.

Van Moorter, B., Visscher, D., Benhamou, S., Börger, L., Boyce, M.S., Gaillard, J., 2009. Memory keeps you at home: a mechanistic model for home range emergence. Oikos 118, 641-652.

Wallendorf, M.J., Porneluzi, P.A., Gram, W.K., Clawson, R.L., Faaborg, J., 2007. Bird response to clear cutting in Missouri Ozark forests. J. Wildlife Manage. 71, 1899-1905.

Wenstrom, W.P., 1974. Habitat selection by brood rearing American woodcock. Proceedings of the Fifth American Woodcock Workshop; 3 - 5 December 1974; Athens, Georgia. US Fish and Wildlife Service. Washington, DC, pp. 154-177.

Williamson, S.J., 2010. American Woodcock: Habitat Best Management Practices for the Northeast. Wildlife Insight 89, US Department of Agriculture, Natural Resources Conservation Service. Washington, DC.

Worton, B.J., 1989. Kernel methods for estimating the utilization distribution in homerange studies. Ecology 70, 164-168.

Zahner, V., Sikora, L., Pasinelli, G., 2012. Heart rot as a key factor for cavity tree selection in the black woodpecker. For. Ecol. Manage. 271, 98-103. 


\section{Fig. 1}

Mean scores for the forest overstory (a), food resource (b), and forest understory (c) habitat components sampled inside and outside the primary diurnal coverts of male woodcock in Kent and Washington Counties, Rhode Island, USA, from 24 August 30 September $2011(n=22)$ and $2012(n=20)$. Primary diurnal coverts exhibited lower forest overstory scores $(P<0.001)$, greater food resource scores $(P=0.009)$, and greater forest understory scores $(P=0.038)$. Whiskers represent $\pm 1 \mathrm{SE}$.

\section{Fig. 2}

Relative probability of use by woodcock of forested land (a) and areas of older second-growth upland forest, generally 60 - 100 years, where woodcock habitat management was deemed most beneficial for increasing relative use (b) in Rhode Island, USA. Relative use was derived from the exponential form of a resource selection function based on a use-availability design. Second-growth upland forest was classified as most beneficial for woodcock habitat management if it occurred on slopes $\leq 53 \%$ and within $1,211 \mathrm{~m}$ of the nearest stream, 1,314 $\mathrm{m}$ of the nearest agricultural opening, 1,498 $\mathrm{m}$ of the nearest upland young forest, and $639 \mathrm{~m}$ of the nearest moist soil. Arcadia Wildlife Management Area, the site where an example case study was conducted, is shown for reference.

\section{Fig. 3}

Relative probability of use by woodcock of forested land in a $4-\mathrm{km}^{2}$ case study area in Arcadia Wildlife Management Area in southwestern Rhode Island, USA, that is considered for forest management (a). The hypothetical forest management scenario considered for this site (b) included creating 30 ha of upland young forest and 10 ha of 
herbaceous forest openings (e.g., wildlife openings or old fields) in areas of older second-growth upland forest (e.g., 60 - 100 years) deemed most beneficial for woodcock habitat management. Following management (c), the estimated extent of low relative use by woodcock of the managed forest decreased by 92 ha while the estimated extents of low-moderate, moderate, and moderate-high relative use increased by 26 ha, 38 ha, and 16 ha, respectively. White areas represent non-forested cover types in panels (a) and (c), and these cover types along with cover types other than older second-growth upland forest in panel (b). 


\section{Table 1}

Initial and remaining number of radio-tagged male woodcock in Kent and Washington Counties, Rhode Island, USA. Woodcock were removed from the initial sample if they died $(n=8)$, slipped their transmitter $(n=7)$, or moved away from study sites and could not be relocated $(n=25)$ prior to obtaining $>25$ telemetry locations during 23 May - 25 August 2011 and 2012. We determined age as either after-second-year (ASY) or second-year (SY) based on plumage characteristics of wings.

\begin{tabular}{|c|c|c|c|c|c|c|}
\hline \multirow[b]{2}{*}{ Age } & \multicolumn{3}{|c|}{2011} & \multicolumn{3}{|c|}{2012} \\
\hline & Arcadia & Big River & Great Swamp & Arcadia & Big River & Great Swamp \\
\hline \multicolumn{7}{|l|}{ ASY } \\
\hline Initial & 11 & 9 & 9 & 7 & 9 & 5 \\
\hline Remaining & 7 & 7 & 3 & 2 & 6 & 3 \\
\hline \multicolumn{7}{|l|}{ SY } \\
\hline Initial & 11 & 5 & 5 & 6 & 5 & 10 \\
\hline Remaining & 6 & 4 & 0 & 4 & 3 & 7 \\
\hline
\end{tabular}




\section{Table 2}

Non-transformed range, mean $\pm \mathrm{SE}$, and median for the variables associated with the forest overstory, food resource, and forest understory habitat components measured inside and outside the primary diurnal coverts of male woodcock in Kent and Washington

Counties, Rhode Island, USA, from 24 August - 30 September $2011(n=22)$ and $2012(n=20)$.

\begin{tabular}{|c|c|c|c|c|c|c|}
\hline \multirow[b]{2}{*}{ Variable } & \multicolumn{3}{|c|}{ Inside diurnal coverts } & \multicolumn{3}{|c|}{ Outside diurnal coverts } \\
\hline & Range & Mean & Median & Range & Mean & Median \\
\hline Canopy closure (\%) & $23.14-98.44$ & $77.79 \pm 3.44$ & 87.26 & $22.83-99.22$ & $83.30 \pm 2.23$ & 87.21 \\
\hline Overstory height class (m) & $1.50-10.50$ & $7.99 \pm 0.42$ & 8.70 & $5.10-10.50$ & $9.34 \pm 0.20$ & 9.60 \\
\hline \multirow[t]{2}{*}{ Tree density (\#/ha) } & $0.00-$ & $465.63 \pm 44.36$ & 382.00 & $178.30-$ & $591.14 \pm 29.23$ & 611.15 \\
\hline & 1196.80 & & & 967.70 & & \\
\hline Basal area $\left(\mathrm{m}^{2} / \mathrm{ha}\right)$ & $0.00-46.30$ & $22.07 \pm 2.30$ & 21.93 & $5.09-67.84$ & $31.27 \pm 2.08$ & 29.98 \\
\hline Medial dbh (cm) & $0.00-41.51$ & $20.62 \pm 1.75$ & 20.87 & $12.11-38.77$ & $26.63 \pm 0.96$ & 26.98 \\
\hline Overstory size class (cm) & $5.80-40.80$ & $22.44 \pm 1.45$ & 23.00 & $11.80-37.80$ & $26.69 \pm 0.91$ & 25.60 \\
\hline Earthworm density $\left(\# / \mathrm{m}^{2}\right)$ & $0.00-95.50$ & $23.70 \pm 4.30$ & 12.20 & $0.00-51.10$ & $7.72 \pm 2.01$ & 0.00 \\
\hline Earthworm fresh weight $\left(\mathrm{g} / \mathrm{m}^{2}\right)$ & $0.00-41.71$ & $8.29 \pm 1.65$ & 3.31 & $0.00-102.69$ & $4.96 \pm 2.51$ & 0.00 \\
\hline
\end{tabular}




\begin{tabular}{|c|c|c|c|c|c|c|}
\hline Earthworm dry weight $\left(\mathrm{g} / \mathrm{m}^{2}\right)$ & $0.00-8.71$ & $1.84 \pm 0.36$ & 0.64 & $0.00-17.47$ & $1.00 \pm 0.45$ & 0.00 \\
\hline Soil moisture content $(\%)$ & $9.33-86.09$ & $40.04 \pm 3.31$ & 35.44 & $11.12-82.39$ & $41.65 \pm 2.86$ & 36.72 \\
\hline Soil organic matter content $(\%)$ & $1.68-87.64$ & $25.87 \pm 3.25$ & 19.46 & $5.71-63.14$ & $29.86 \pm 2.53$ & 29.22 \\
\hline \multirow[t]{2}{*}{ Shrub and sapling density (\#/ha) } & $2,500.00-$ & $21,452.38 \pm$ & $15,500.00$ & $0.00-$ & $11,488.10 \pm$ & $7,750.00$ \\
\hline & $78,500.00$ & $2,704.03$ & & $33,000.00$ & $1,457.64$ & \\
\hline
\end{tabular}




\section{Table 3}

Coefficient values $(\beta)$ for each of the variables included in the three highest-ranked resource selection functions relating the relative probability of use by woodcock of forested land from 23 May - 25 August 2011 and 2012 to geographic variables in Rhode Island, USA. Coefficients were derived using logistic regression under a useavailability design. Variables included elevation, slope, forest cover type (ForCov), and Euclidean distance to the nearest stream (D2Strm), agricultural opening (D2Ag), upland young forest (D2UYF), and moist soil (D2MS). Coefficients for forest cover type were estimated using dummy variables with mixed upland forest serving as the reference category.

\begin{tabular}{llll}
\hline$\beta$ & Model 1 & Model 2 & Model 3 \\
\hline Elevation & 0.00210 & & 0.00165 \\
Slope & -0.01870 & -0.01760 & \\
ForCov & & & \\
CUF & -0.31110 & -0.32520 & -0.31970 \\
DUF & 0.09060 & 0.08440 & 0.07260 \\
UYF & -0.22690 & -0.26200 & -0.19820 \\
CWF & -0.02730 & -0.05390 & 0.03100 \\
DWF & 0.68390 & 0.61330 & 0.75650 \\
MWF & 0.19930 & 0.15660 & 0.26160 \\
WYF & 0.39340 & 0.32270 & 0.47500 \\
D2Strm & -0.00080 & -0.00083 & -0.00075 \\
D2Ag & -0.00162 & -0.00162 & -0.00163
\end{tabular}




\begin{tabular}{llll} 
D2UYF & -0.00025 & -0.00021 & -0.00025 \\
D2MS & -0.00117 & -0.00106 & -0.00135 \\
\hline
\end{tabular}

${ }^{a}$ coniferous upland forest (CUF), deciduous upland forest (DUF), upland young forest (UYF), coniferous wetland forest (CWF), deciduous wetland forest (DWF), mixed wetland forest (MWF), and wetland young forest (WYF). 

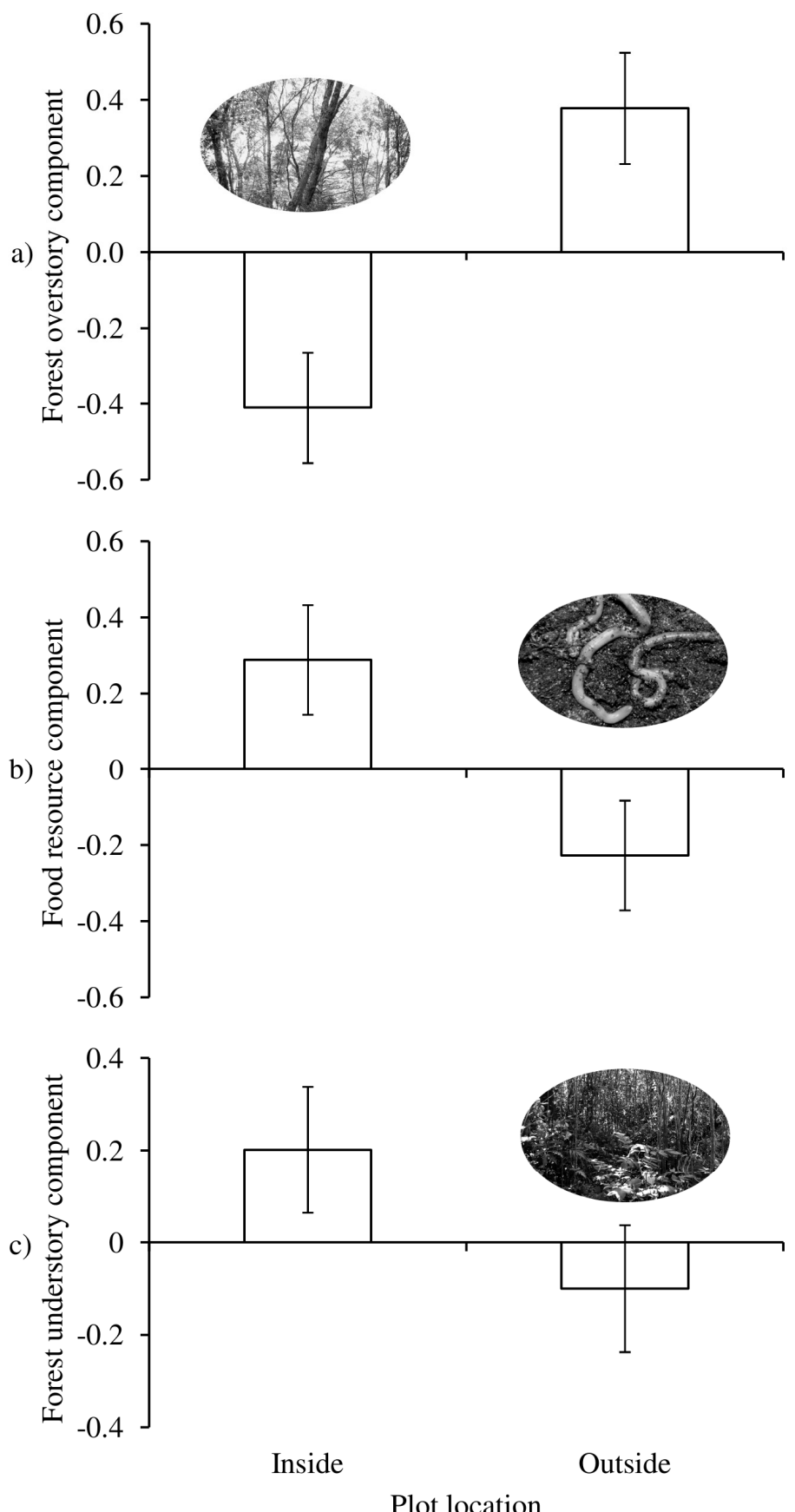

Fig. 1 

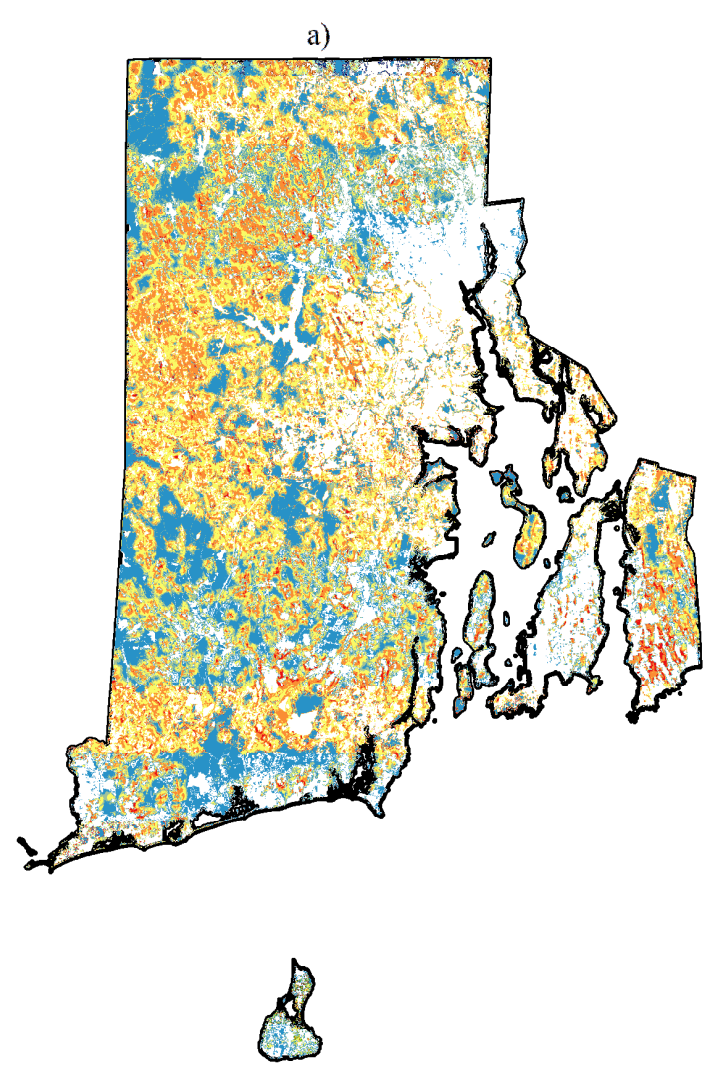

Relative probability of use

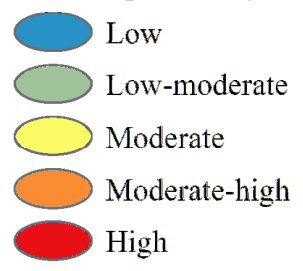

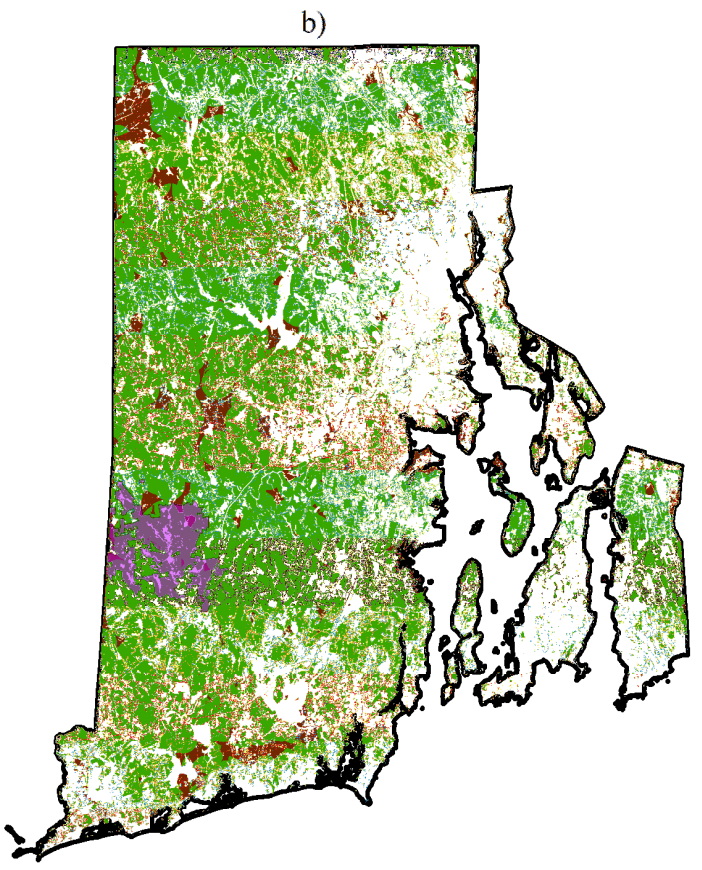

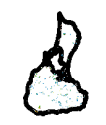

Upland forest management potential

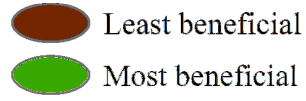

Arcadia wildlife management area

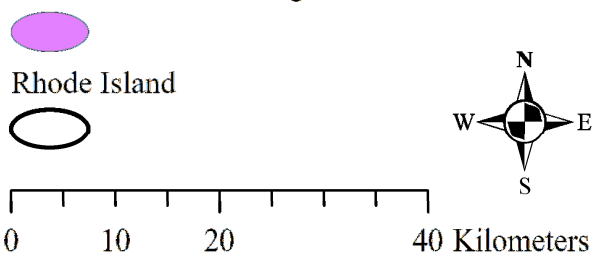

Fig. 2 


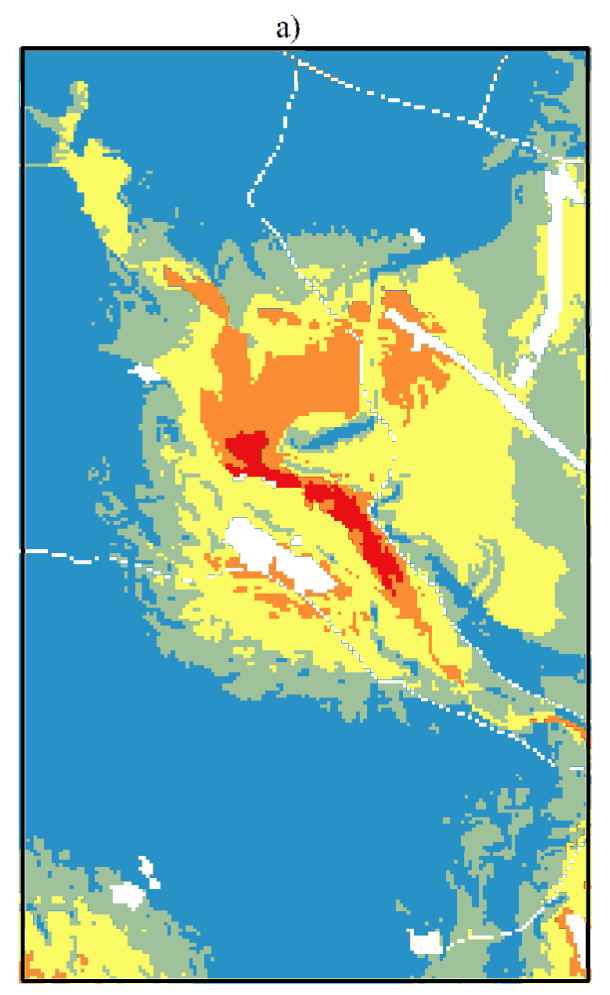

c)

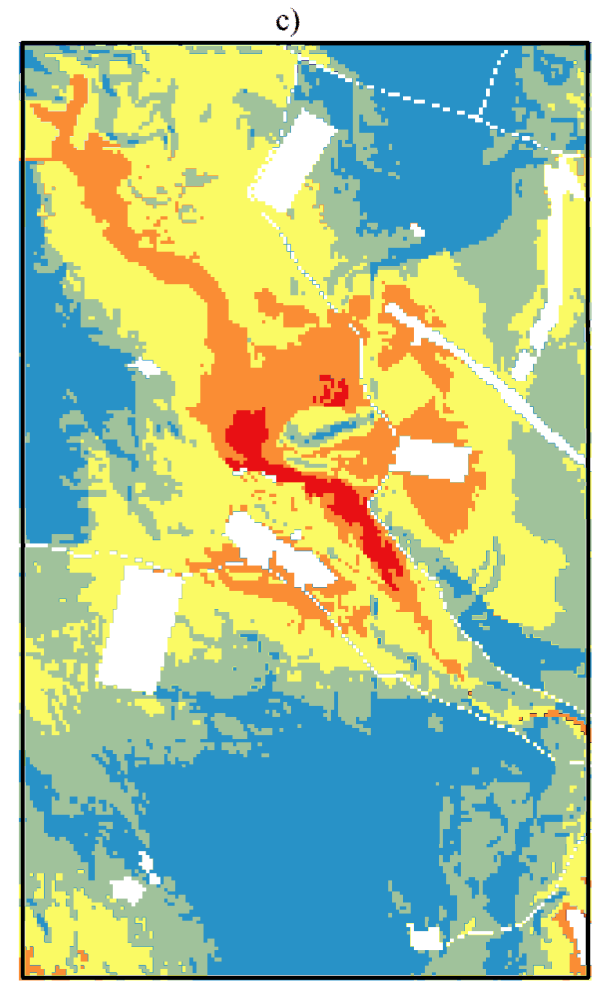

Fig. 3

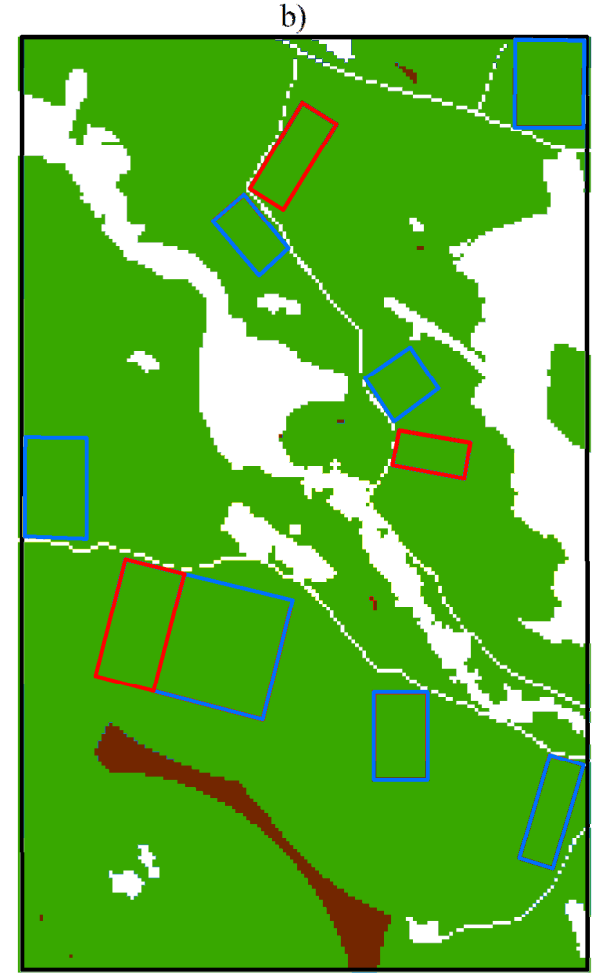

Relative probability of use

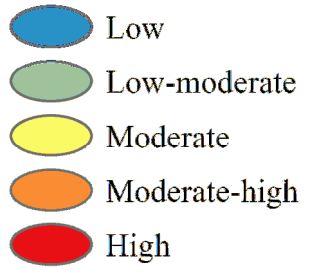

Upland forest management potential

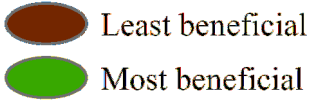

Example forest management units

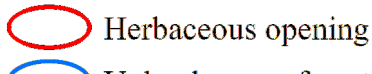
Upland young forest Case study area
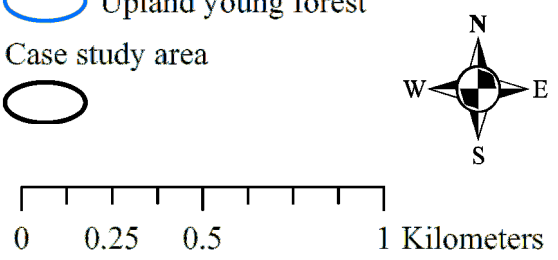


\section{Appendix A. Supplementary material.}

\section{Table A.1.}

Loadings (correlations) for retained principle components in relation to 13 quantitative habitat variables measured inside and outside the primary diurnal coverts of male woodcock in Kent and Washington Counties, Rhode Island, USA, from 24 August - 30 September $2011(n=22)$ and $2012(n=20)$.

\begin{tabular}{lccc}
\hline Habitat variable & Forest overstory & Food resource & Forest understory \\
& component & component & component \\
\cline { 2 - 4 } Soil pH & -0.526 & 0.398 & 0.405 \\
Soil moisture content $(\%)$ & 0.461 & 0.287 & 0.780 \\
Soil organic matter content $(\%)$ & 0.496 & 0.161 & 0.766 \\
Earthworm density $\left(\# / \mathrm{m}^{2}\right)^{\mathrm{a}}$ & -0.477 & 0.822 & -0.055 \\
Earthworm fresh weight $\left(\mathrm{g} / \mathrm{m}^{2}\right)^{\mathrm{a}}$ & -0.447 & 0.866 & -0.120 \\
Earthworm dry weight $\left(\mathrm{g} / \mathrm{m}^{2}\right)^{\mathrm{a}}$ & -0.456 & 0.820 & -0.191 \\
Canopy closure $(\%)$ & 0.822 & 0.179 & 0.039
\end{tabular}


Overstory height class (m)

Tree density (\#/ha)

Basal area $\left(\mathrm{m}^{2} / \mathrm{ha}\right)$

Medial dbh $(\mathrm{cm})$

Overstory size class $(\mathrm{cm})$

Shrub and sapling density (\#/ha)

$-0.258$
0.263

0.342

0.227

0.198

0.175

$-0.081$

0.713

${ }^{a} \log$-transformed prior to conducting the principal components analysis. 


\section{Table A.2}

Fifteen a priori logistic regression models used to derive coefficients for resource selection functions relating the relative probability of use by woodcock of forested land from 23 May - 25 August 2011 and 2012 to geographic variables in Rhode Island, USA.

Variables included elevation (E), slope (S), forest cover type (ForCov), and Euclidean distance to the nearest stream (D2Strm), agricultural opening (D2Ag), upland young forest (D2UYF), and moist soil (D2MS). Akaike Information Criterion (AIC), $\triangle$ AIC, and Akaike weights $\left(w_{\mathrm{i}}\right)$ are provided for model comparison.

\begin{tabular}{|c|c|c|c|c|}
\hline Model & Variables & AIC & $\Delta \mathrm{AIC}$ & $w_{i}$ \\
\hline 1 & E, S, ForCov, D2Strm, D2Ag, D2UYF, D2MS & $22,469.76$ & 0.00 & 0.94 \\
\hline 2 & S, ForCov, D2Strm, D2Ag, D2UYF, D2MS & $22,475.42$ & 5.66 & 0.06 \\
\hline 3 & E, ForCov, D2Strm, D2Ag, D2UYF, D2MS & $22,497.92$ & 28.16 & 0.00 \\
\hline 4 & ForCov, D2Strm, D2Ag, D2UYF, D2MS & $22,500.64$ & 30.88 & 0.00 \\
\hline 5 & ForCov, D2Strm, D2Ag, D2UYF & $22,530.29$ & 60.53 & 0.00 \\
\hline 6 & ForCov, D2Ag, D2UYF, D2MS & $22,561.01$ & 91.25 & 0.00 \\
\hline 7 & E, ForCov, D2Ag, D2MS & $22,565.80$ & 96.05 & 0.00 \\
\hline
\end{tabular}




\begin{tabular}{ccccc}
8 & ForCov, D2Ag, D2UYF & $22,644.97$ & 175.21 & 0.00 \\
9 & E, S, D2Strm, D2Ag, D2UYF, D2MS & $22,676.68$ & 206.92 & 0.00 \\
10 & S, D2Strm, D2Ag, D2UYF, D2MS & $22,678.42$ & 208.67 & 0.00 \\
11 & D2Ag, D2UYF, D2MS & $22,816.95$ & 347.20 & 0.00 \\
12 & S, ForCov, D2Strm, D2UYF, D2MS & $22,962.59$ & 492.83 & 0.00 \\
13 & S, ForCov, D2Strm, D2UYF & $22,978.46$ & 508.71 & 0.00 \\
14 & ForCov, D2Strm, D2UYF, D2MS & $22,992.03$ & 522.27 & 0.00 \\
un 15 & ForCov, D2Strm, D2UYF & $23,017.66$ & 547.90 & 0.00 \\
\hline
\end{tabular}




\section{CHAPTER 2}

"Why Woodcock Commute: Testing the Foraging-benefit and Predation-risk

\section{Hypotheses"}

by

Roger J. Masse ${ }^{1,3}$, Brian C. Tefft ${ }^{2}$, José A. Amador ${ }^{1}$, and Scott R. McWilliams ${ }^{1}$

is published in Behavioral Ecology

${ }^{1}$ Department of Natural Resources Science, University of Rhode Island, 102 Coastal Institute in Kingston, Kingston, RI 02881, USA.

${ }^{2}$ Rhode Island Department of Environmental Management, Division of Fish and Wildlife, 277 Great Neck Road, West Kingston, RI 02892, USA.

${ }^{3}$ Corresponding author; e-mail: rjmasse@my.uri.edu. 


\begin{abstract}
Moving between sites is a common behavior employed by prey in order to balance trade-offs associated with acquiring resources and avoiding predators. At dusk during summer, American woodcock (Scolopax minor) frequently fly from diurnal coverts in forests to nocturnal roost fields. We tested two hypotheses, the foraging-benefit hypothesis and predation-risk hypothesis, to determine the benefit gained by woodcock that commute. We used telemetry to identify the diurnal coverts and nocturnal roost fields used by woodcock in Rhode Island, USA during two summers. At each site we measured the availability and diversity of woodcock prey, soil properties, and mammalian predator activity. Earthworms were 3-4 times more abundant at diurnal coverts than nocturnal roost fields. The richness and diversity of woodcock foods was greater at diurnal coverts during 2011, but similar between sites during 2012. Soil moisture content was about 1.5 times greater at diurnal coverts whereas other soil properties were similar between sites. At night, mammalian predators visited diurnal coverts more frequently than nocturnal roost fields for $73 \%$ of the woodcock we monitored during 2011. During 2012, the number of days until initial predator visit was 1.8 times greater at nocturnal roost fields. Our results provide the first empirical support for the predation-risk hypothesis. During summer, woodcock fly from diurnal coverts to nocturnal roost fields to avoid predators and not to feed.
\end{abstract}




\section{INTRODUCTION}

Prey must balance the costs and benefits of acquiring resources while avoiding predators (Milinski and Heller 1978; Sih 1980; Lima 1985; Lima et al. 1985; Lima and Dill 1990). The predation risk allocation hypothesis states that temporal variation in predation risk imposed on prey by predators often forces prey to trade-off when to feed and when to engage in antipredator behaviors during periods of dissimilar risk (Lima and Bednekoff 1999). This hypothesis, and its associated predictions, has recently been questioned on the grounds that some assumptions may be unrealistic in ecological settings, specifically the assumption that prey experience imposed schedules of risk for set periods, and thus, cannot actively manage risk (Beauchamp and Ruxton 2011). On the contrary, antipredator behaviors allow prey to actively manage risk, but prey are unable to control when and where predators occur and so decisions to adopt such behaviors are made under risk imposed by predators (Bednekoff and Lima 2011). Discriminating between these scenarios requires studies that demonstrate spatial or temporal variation in predation risk and then show how certain antipredator behavior(s) can favorably balance predation risk and the need to feed.

Active risk management via antipredator behaviors has been documented for diverse taxa including insects (Rothley et al. 1997), amphibians (Van Buskirk et al. 2002), fishes (Ferrari et al. 2010), mammals (Searle et al. 2008; Périquet et al. 2012), and birds (Tilgar et al. 2011; Huang et al. 2012). One behavior aimed at balancing the trade-off between acquiring resources and avoiding predators involves moving between sites. For instance, red-backed salamanders (Plethodon cinereus) exposed to 
simulated predation climbed higher on plants than controls and so moved farther away from food-rich areas which were on the ground (Roberts and Liebgold 2008).

Similarly, shorebirds frequently fly between shallow feeding areas at low-tide and safe resting areas with less food at high-tide (Dias et al. 2006; Rogers et al. 2006; van Gils et al. 2006). Organisms that typically move between sites provide behavioral ecologists unique opportunities to investigate the timescales at which predation risk allocation may occur and simultaneously test hypotheses about the trade-offs between foraging and predation risk at different sites. We investigated these aspects of the behavioral ecology of the American woodcock (Scolopax minor), a 116-279-g shorebird that inhabits forests and shrublands in eastern North America (Keppie and Whiting 1994).

American woodcock (hereafter woodcock) are a migratory species breeding primarily across the northern half of the eastern United States and adjacent southern Canada and wintering primarily across the southern and southeastern United States. Generally, woodcock return to northern breeding grounds during March and depart for southern wintering grounds during October (Keppie and Whiting 1994). Throughout the year woodcock often commute between quite different vegetation types during the day and night, although the reasons for this behavior can vary by season. During fall and winter, woodcock frequently fly from forests to grazed pastures, recent forest clearcuts, or harvested agricultural fields at dusk to actively feed (Glasgow 1958; Krohn et al. 1977; Krementz 2000; Blackman et al. 2012) or roost (Connors and Doerr 1982). During spring, woodcock fly from forests to recent forest clearcuts, maintained or abandoned meadows and fields, tree plantations, or other forest openings during the 
morning and evening crepuscular periods to perform courtship displays and copulate (Sheldon 1967; Dwyer et al. 1988). Male woodcock perform courtship flights over these forest openings, called singing grounds, whereas females typically nest and rear young in nearby forests (Sheldon 1967). During summer, woodcock typically spend the day feeding in moist, young, deciduous or mixed hardwood-conifer forests (Sheldon 1967; Straw et al. 1986; Keppie and Whiting 1994; McAuley et al. 1996; Dessecker and McAuley 2001), called diurnal coverts, and then some fly to natural or maintained forest openings at dusk (Mendall and Aldous 1943; Sheldon 1961; Krohn 1971). Although these movements by woodcock during summer have been described, the benefits gained by woodcock that fly to forest openings at dusk are not clear.

Two hypotheses, the foraging-benefit hypothesis (Mendall and Aldous 1943; Sheldon 1961) and the predation-risk hypothesis (Dunford and Owen 1973), have been proposed to explain why woodcock fly to forest openings, called nocturnal roost fields, at dusk to spend the night during summer. Observations of some woodcock feeding on invertebrates (e.g., ants [Hymenoptera], moths [Lepidoptera], and beetle [Coleoptera] larvae) at nocturnal roost fields prompted early researchers to hypothesize that those birds flew to these areas to exploit novel food resources that were not available at diurnal coverts (Mendall and Aldous 1943; Sheldon 1961; Sheldon 1967). Although earthworms (Haplotaxida) are favored woodcock foods, other invertebrates may account for $15-40 \%$ of the volume of food in woodcock stomachs (Sheldon 1967; Keppie and Whiting 1994). Because woodcock are opportunistic feeders (Sheldon 1967) it is likely that many of these prey items could be obtained at diurnal coverts. Moreover, no one to date has directly tested the 
foraging-benefit hypothesis by quantifying the availability or diversity of woodcock foods at both the diurnal coverts and nocturnal roost fields used by individuals.

Subsequent research found that little, or no, feeding occurred by woodcock at nocturnal roost fields during summer (Krohn 1970). Furthermore, nocturnal roost fields used by woodcock during summer typically are not conducive to feeding because the soils at these sites tend to be dry, hard, and lacking in potential prey items (Sheldon 1961; Krohn 1970; Wishart and Bider 1976). After flying to nocturnal roost fields, woodcock are usually inactive throughout the night during summer (Dunford and Owen 1973; Owen and Morgan 1975; Wishart and Bider 1977) so these areas likely provide some benefit other than feeding opportunities. Dunford and Owen (1973) suggested that woodcock flew from diurnal coverts to nocturnal roost fields during summer because these areas provided safer refuge from predators. While it is generally accepted (e.g., Williamson 2010), no one to date has directly tested the predation-risk hypothesis.

Our objective was to simultaneously test the foraging-benefit and predation-risk hypotheses for woodcock that fly between diurnal coverts and nocturnal roost fields during summer to determine the benefit afforded to individuals engaging in this behavior. Specifically, we compared the availability and diversity of woodcock foods, soil properties, and mammalian predator activity at both the diurnal coverts and nocturnal roost fields used by individually-marked woodcock. The foraging-benefit hypothesis predicts greater availability and diversity of soil macrofauna at woodcock nocturnal roost fields than diurnal coverts. The predation-risk hypothesis predicts 
greater mammalian predator activity during the night at woodcock diurnal coverts than nocturnal roost fields.

\section{MATERIALS AND METHODS}

We conducted this field study within and around three state wildlife management areas - Arcadia, Big River, and Great Swamp - in central and southern Rhode Island, USA. Arcadia $\left(41^{\circ} 35^{\prime} 10^{\prime \prime} \mathrm{N}, 71^{\circ} 43^{\prime} 20^{\prime \prime} \mathrm{W}\right)$ is approximately $62 \mathrm{~km}^{2}$ predominantly comprised of mixed (35\%), deciduous (35\%), and coniferous forest (26\%) with roughly $88 \%$ of the management area consisting of upland habitat; Big River $\left(41^{\circ} 37^{\prime}\right.$ $\left.0^{\prime \prime} \mathrm{N}, 71^{\circ} 36^{\prime} 60^{\prime \prime} \mathrm{W}\right)$ is approximately $33 \mathrm{~km}^{2}$ mainly comprised of coniferous (46\%), mixed (34\%), and deciduous forest (8\%) with nearly $84 \%$ of the management area consisting of upland habitat; Great Swamp (412 $\left.27^{\prime} 15^{\prime \prime} \mathrm{N}, 71^{\circ} 35^{\prime} 19^{\prime \prime} \mathrm{W}\right)$ is approximately $15 \mathrm{~km}^{2}$ chiefly comprised of deciduous (61\%), mixed (18\%), and coniferous forest ( $8 \%$ ) with only about $31 \%$ of the management area consisting of upland habitat (RIGIS 2012). Red maple (Acer rubrum) swamps are the dominant wetland type at Great Swamp. Common trees and shrubs at all sites included red maple, oaks (Quercus spp.), eastern white pine (Pinus strobus), pitch pine (Pinus rigida), blueberries (Vaccinium spp.), and pepperbush (Clethra alnifolia).

At each management area a variety of maintained forest openings including recent forest clearcuts, herbaceous meadows, and agricultural fields are managed to improve woodcock habitat. In 1995, a series of 2-5-ha clearcuts were made at Great Swamp to provide forest openings and create young forest habitat. Additional habitat management occurred at that site during 2007 and 2012. Similar management 
practices were initiated at Arcadia and Big River during 1996 and 2006, respectively, and have continued sporadically since then.

\section{Woodcock movements and data collection}

We used mist nets to catch adult woodcock on singing grounds, where males perform courtship flights and copulate with females (Sheldon 1967), during April-June 2011 and 2012 as part of a separate study investigating the distribution, habitat selection, and survival of woodcock in the region (IACUC protocol AN10-02-017). We attached an Advanced Telemetry Systems Model A5400, two-stage transmitter to each bird using all-weather cattle tag cement and a wire belly band ( $\leq 4 \mathrm{~g}$; McAuley et al. 1993). We marked 98 adult woodcock between 2011 ( $n=54 ; 50$ males and four females) and $2012(n=44 ; 42$ males and two females). Females were underrepresented in our sample because of the difficulty associated with catching them in mist nets during spring (McAuley et al. 1993). During 2011, six woodcock died, four slipped their transmitters, and 20 left the study sites and could not be relocated prior to the start of field experiments. During 2012, six woodcock died, four slipped their transmitters, and ten left the study sites and could not be relocated prior to the start of field experiments. All of the 48 remaining woodcock (2011: 15 after-second-year [ASY] and nine second-year [SY] males; 2012: ten ASY and 13 SY males and one ASY female) flew from diurnal coverts to nocturnal roost fields on some nights.

For the present study, we monitored the daytime and nighttime locations of radiomarked woodcock 1-3 times per week from 1 July-20 August each year. We tracked each individual on foot using a three-element antenna and used a GPS to determine exact locations once each day (0600-1900 hrs EST) and once each night (2030-0240 
hrs). The location of each bird was determined by slowly moving in the direction of the radio signal while reducing the gain of the receiver until the receiver began giving an audible signal without the use of the antenna or headphones. We quantified the accuracy of this technique by placing five transmitters on the ground, approaching each transmitter from each cardinal direction, then measuring the distance to the transmitter once the receiver first started giving an audible signal without the antenna or headphones. On average, we were (mean \pm SD) $17.7 \pm 8.3 \mathrm{~m}$ from transmitters using this technique. Because we were interested in determining which variables cause woodcock to fly between diurnal coverts and nocturnal roost fields, we identified the location of the diurnal covert and nocturnal roost field used during a 6-day period for each bird included in this study. This paired design allowed us to directly compare the foraging-benefit and predation-risk associated with each bird's diurnal covert and nocturnal roost field.

We collected soil macrofauna at the nocturnal roost field and diurnal covert of each woodcock by digging five $900-\mathrm{cm}^{2}$ soil pits to $10-\mathrm{cm}$ deep. We flushed each woodcock once at its nocturnal roost field from 8-20 August 2011 and from 9 July-7 August 2012 and centered the first soil pit on the flush point. Four additional soil pits were located $5 \mathrm{~m}$ in each cardinal direction from the flush point to provide an overall average density of soil macrofauna at each site. We stored soil pit contents in plastic bags that were tied shut, returned early the following morning, then collected all soil macrofauna by hand sorting similar to Dangerfield (1997) except we sorted pit contents over white plastic bags. On subsequent days we flushed each woodcock once at its diurnal covert and collected potential prey in the same manner, but immediately 
hand sorted soil pit contents after digging. We counted all soil macrofauna and identified individuals to Order except centipedes (Chilopoda) and millipedes (Diplopoda). Since earthworms are the dominant prey of woodcock (Sheldon 1967) we also weighed fresh and freeze-dried earthworm samples from each site. We tested the foraging-benefit hypothesis using 38 of the available radio-marked woodcock (2011: nine ASY and eight SY males; 2012: eight ASY and 12 SY males and one ASY female) because we had complete information on food abundance at both their diurnal coverts and nocturnal roost fields.

We collected a 10-cm deep soil core from the flush point and two randomly chosen soil pits at each diurnal covert and nocturnal roost field to determine soil moisture content and soil $\mathrm{pH}$ during 2011 and these variables along with soil organic matter content during 2012. We measured soil moisture content gravimetrically by drying to a constant weight at $105^{\circ} \mathrm{C}$. We measured soil $\mathrm{pH}$ using a $1: 5$ soil/water (mass/vol) ratio (Hendershot et al. 1993) with a glass $\mathrm{pH}$ electrode and a $\mathrm{pH}$ meter (model UB-10; Denver Instruments). We measured soil organic matter content using the loss-on-ignition method via combustion of oven-dry $\left(105^{\circ} \mathrm{C}\right)$ soil in a furnace at $550^{\circ} \mathrm{C}$ for $4 \mathrm{hr}$. We expressed soil moisture content and soil organic matter content as percent by weight.

We quantified mammalian predator activity at the diurnal covert and nocturnal roost field of each woodcock in two ways. First, during 2011, we established baited track stations (Linhart and Knowlton 1975; Gompper et al. 2006) at each site and monitored them for evidence of mammalian predator activity for ten nights each from 2-30 September. We expanded the soil pit at each flush point to $1 \mathrm{~m}^{2}$ by loosening and 
smoothing the soil and baited each station with a 0.25 can of albacore tuna (Thunnus alalunga). We prepared track stations during the late afternoon and checked them for evidence of mammalian predator activity (e.g., tracks, dig marks, or missing bait) early the following morning. For each site we recorded the total number of nights (out of ten) that any mammalian predator visited and, when possible, predator identity. Second, during 2012, we established bait stations at each site in the same manner and monitored them constantly for up to 14 days using camera traps (Gompper et al. 2006) from 6-31 August. We baited each station with a 0.25 can of albacore tuna and a single northern bobwhite (Colinus virginianus) carcass and replenished bait after seven days as necessary. For each site we recorded the number of days until initial predator visit along with predator identity. During both years, we delayed the start of predator monitoring at these sites until after all soil macrofauna were collected (2011: average $=19$ days, range $=12-24$ days; $2012:$ average $=17$ days, range $=1-31$ days $)$ in order to minimize the influence of these activities on predator behavior and ensure that all sites were monitored for predator activity during a similar time period within each year. Because several woodcock might roost in the same forest opening at night (Sheldon 1967) we randomly selected one woodcock from forest openings where $>1$ radio-tagged bird was present to include in our sample. This reduced our sample size, but was necessary to ensure independence between pairs of observations. We tested the predation-risk hypothesis using 23 of the 38 woodcock (2011: six ASY and five SY males; 2012: four ASY and eight SY males) included in the test of the foragingbenefit hypothesis because these individuals satisfied our independence criteria and 
we had complete information on mammalian predator activity at both their diurnal coverts and nocturnal roost fields.

We acknowledge that raptors are also important predators of woodcock. Great horned owls (Bubo virginianus) and barred owls (Strix varia) may occasionally kill woodcock in forest openings at night during spring and summer (Derleth and Sepik 1990; Longcore et al. 1996), but mammalian predators, particularly weasels (Mustela spp.) and raccoons (Procyon lotor), pose a more serious threat at diurnal coverts (Longcore et al. 2000; McAuley et al. 2005).

\section{Statistical analysis}

We calculated the population density of each potential prey item at each diurnal covert and nocturnal roost field used by each woodcock. Since woodcock might not consume all macrofauna found in the soil we also calculated the cumulative density of known woodcock foods (see Keppie and Whiting 1994) at each site. We estimated the richness of soil macrofauna at each site by counting the number of unique taxonomic groups and estimated diversity by calculating the Shannon Index, H', (Magurran 2004) and then converting to diversity (Jost 2006). We used either paired $t$-tests or Wilcoxon signed-rank tests (Ott and Longnecker 2010) to compare population densities of potential prey, cumulative densities of known prey, richness, and diversity depending on the normality of paired differences. We assessed normality using a combination of histograms, boxplots, or normal probability plots. We also used paired $t$-tests or Wilcoxon signed-rank tests to compare earthworm weight, soil moisture content, soil $\mathrm{pH}$, and soil organic matter content. We tested for a difference in the number of nights that baited track stations were visited by any mammalian predator during 2011 using 
log-linear regression assuming a Poisson distribution (Gardner et al. 1995; Agresti 2007; Pedan 2011). We used a mixed effects model (PROC GLIMMIX, SAS Version 9.2) and included bird identity as a random effect to account for the paired nature of our data. Finally, we used a paired $t$-test to compare the number of days until initial predator visit at each site during 2012. Unless otherwise stated, we used Program R (Version 2.10.1) to conduct these analyses. We considered a significance level of $\alpha=$ 0.05 for all tests.

\section{RESULTS}

Woodcock flew on average 1,201 $\pm 594 \mathrm{~m}$ (range: 402-2,236 m) in 2011 (17 males; one observation per bird) and on average $874 \pm 544 \mathrm{~m}$ (range: $85-2,133 \mathrm{~m}$ ) in 2012 (20 males and one female; one observation per bird) between sample locations at diurnal coverts and nocturnal roost fields.

During 2011, all potential prey items found at woodcock nocturnal roost fields were also found at diurnal coverts (Table 1). Average population densities of millipedes and earthworms were about 49 times greater $(\mathrm{V}=78.00, P<0.01)$ and 3 times greater $\left(t_{16}=2.14, P=0.02\right)$, respectively, at diurnal coverts whereas the average population density of ants was about 10 times greater $(\mathrm{V}=5.00, P=0.04)$ at nocturnal roost fields. Average population densities of all other soil macrofauna were similar between sites ( $P \geq 0.09$; Table 1). During 2012, cockroaches (Blattodea), centipedes, and butterfly/moth larvae were unique to nocturnal roost fields, but average population densities of these were extremely low (Table 2). The average population density of beetles was nearly 3 times greater $(\mathrm{V}=26.00, P=0.01)$ at nocturnal roost fields while average population densities of earthworms and pillbugs 
(Isopoda) were approximately 4 times greater $\left(t_{20}=2.52, P=0.01\right)$ and 8 times greater ( $\mathrm{V}=60.00, P=0.02$ ), respectively, at diurnal coverts. Average population densities of all other soil macrofauna were similar between sites $(P \geq 0.09$; Table 2$)$. During both years, earthworm fresh weight $(P<0.03)$ and dry weight $(P<0.03)$ were greatest at diurnal coverts (Figure 1a), and the cumulative density of known woodcock foods was similar between sites $(P \geq 0.39$; Figure $1 b)$. During 2011 we found greater richness $\left(t_{16}\right.$ $=2.85, P=0.01)$ and diversity $\left(t_{16}=2.30, P=0.04\right)$ of soil macrofauna at diurnal coverts, but these measures were similar between sites during 2012 ( $P \geq 0.46$; Figure 1c).

Generally, radio-marked woodcock spent the day in forested wetlands, floodplain forests, or moist upland forests and flew to small forest clearcuts, maintained or abandoned herbaceous meadows, or other idle agricultural fields to spend the night. At diurnal coverts, soil moisture content during $2011(41.6 \pm 25.1 \%)$ and $2012(43.3 \pm$ $28.5 \%)$ was 1.7 times greater $\left(t_{16}=2.97, P<0.01\right)$ and 1.5 times greater $\left(t_{20}=2.67, P\right.$ $=0.01)$, respectively, than at nocturnal roost fields. Soil $\mathrm{pH}$ was similar between sites during both years $(P \geq 0.22)$ and we found no evidence that soil organic matter content differed between sites $(P=0.09)$.

During 2011, nocturnal mammalian predators visited baited track stations at diurnal coverts more frequently than nocturnal roost fields for about $73 \%$ ( 8 of 11) of the woodcock that we monitored $\left(F_{1,10}=8.11, P=0.02\right.$; Figure 2$)$. We observed raccoon, mink (Neovison vison), red fox (Vulpes vulpes), coyote (Canis latrans), domestic cat (Felis catus), striped skunk (Mephitis mephitis), domestic dog (Canis familiaris), and unidentified canid and mustelid tracks at sites used by woodcock. 
During 2012, the number of days until initial predator visit was approximately 1.8 times greater at nocturnal roost fields than diurnal coverts $\left(t_{11}=2.02, P=0.03\right.$; Figure 3). We photographed raccoon, fisher (Martes pennanti), coyote, red fox, Virginia opossum (Didelphis virginiana), striped skunk, domestic cat, and long-tailed weasel (Mustela frenata) at sites used by woodcock. We also photographed one broad-winged hawk (Buteo platypterus) at a diurnal covert and one red-tailed hawk (Buteo jamaicensis) at a nocturnal roost field.

\section{DISCUSSION}

Our results show that the benefit afforded to woodcock that fly between diurnal coverts and nocturnal roost fields during summer is one of reduced predation risk and not novel feeding opportunities. Several lines of evidence support this conclusion. First, nearly all soil macrofauna that we found at nocturnal roost fields were also found at diurnal coverts and the population densities of potential prey were not consistently greater at nocturnal roost fields. Second, preferred woodcock foods (i.e., earthworms) were always more abundant at diurnal coverts, the cumulative density of known woodcock foods was similar between sites, and the richness and diversity of soil macrofauna was similar or greater at diurnal coverts depending on the year. Third, two separate indices of predator activity suggest that nocturnal mammalian predators are more active at diurnal coverts. Taken together, this evidence provides the first empirical support for the predation-risk hypothesis and against the foraging-benefit hypothesis to explain the function of woodcock commuting between forests and fields during summer. 


\section{Why woodcock commute during summer}

Previous studies have indicated that woodcock do not move to forest openings at night to feed during summer (Krohn 1970; Dunford and Owen 1973; Owen and Morgan 1975; Wishart and Bider 1977). At a field in Maine, USA, only one earthworm and few other potential woodcock foods including ants, beetle larvae, and spiders (Araneae) were found in soil collected at night at ten woodcock flush points and 20 random points (Krohn 1970). Further, the stomach contents of most birds collected from ten fields at various times during the night contained few if any earthworms or other soil macrofauna (Krohn 1970). In contrast, earthworms were prevalent in the stomachs of birds collected immediately before or after landing in forest openings at night in Maine (Krohn 1970) and Massachusetts, USA (Sheldon 1961). This suggests that feeding occurs predominantly at diurnal coverts prior to flying to nocturnal roost fields.

However, an important difference between our study and previous ones is that our paired design allowed us to directly compare food availability at both diurnal and nocturnal sites for individuals that commuted. Since earthworms are the dominant prey of woodcock (Sheldon 1967) our findings of greater earthworm availability at diurnal coverts further support the conclusion that most feeding likely occurs at these sites. Although some woodcock have been observed feeding soon after moving to forest openings at night during summer (Sheldon 1961) this may simply represent infrequent opportunistic foraging (Sheldon 1967). Generally, woodcock were sedentary after moving to fields at night during summer in Quebec, Canada (Wishart and Bider 1977) and Maine (Dunford and Owen 1973; Owen and Morgan 1975). This 
contrasts with behaviors observed in forest openings at night during fall and winter in New Jersey (Krohn et al. 1977), North Carolina (Stribling and Doerr 1985), and Louisiana, USA (Glasgow 1958), where woodcock actively fed at night. The reasons for this seasonal difference in behavior are not well understood, but higher food availability at nocturnal roost fields during fall (Krohn et al. 1977) and winter (Blackman et al. 2012) may be a driving factor.

We simultaneously documented less nocturnal mammalian predator activity at nocturnal roost fields than at diurnal coverts. In addition to visiting baited track stations less frequently at night, mammalian predators took longer to find bait stations at nocturnal roost fields than diurnal coverts. In the northeastern USA, weasels and raccoons were major ground predators of woodcock (Derleth and Sepik 1990; McAuley et al. 2005). Many mammalian predators concentrate their activity along habitat edges or within wooded areas adjacent to edges and not within forest openings such as fields (Bider 1968; Gehring and Swihart 2003; Šálek et al. 2010). Thus, woodcock flying to forest openings at night during summer should be safer since these areas are less likely to be searched by potential predators. Eurasian woodcock (Scolopax rusticola) may experience increased predation risk in fields at night during winter (Duriez et al. 2005), whereas such predation risk in fields at night during winter is inadequately documented for American woodcock.

We acknowledge that raptors are important woodcock predators, especially during the spring courtship period when conspicuous male displays are likely to attract attention (Sheldon 1967; Longcore et al. 1996). However, it is logistically difficult to quantify the risk of depredation by raptors to woodcock during summer nights when 
the latter is sedentary. We attempted to accomplish this by monitoring raptor visits to caged rock pigeons (Columba livia) placed at diurnal coverts and nocturnal roost fields (IACUC protocol AN12-03-019) since rock pigeons are typically excellent lures for attracting raptors (Berger and Hamerstrom 1962). Surprisingly, we never documented a raptor visit at either site from 17 July-5 August 2012 despite constant surveillance using camera traps. Consequently, we have no reason to expect woodcock are at greater risk of raptor depredation at nocturnal roost fields where they are sedentary throughout the night. Nevertheless, additional research using alternative methods, such as call count surveys (Rogers and Dauber 1977; Fuller and Mosher 1981), to quantify raptor activity around woodcock diurnal coverts and nocturnal roost fields may be warranted.

Fully understanding the function of woodcock commuting behavior during summer is complicated by differential habitat use patterns between age-sex classes. On average, juvenile males fly to forest openings at night more often than all other age-sex classes from June-October and males tend to fly to forest openings at night more often than females (Sepik and Derleth 1993). In contrast, female woodcock may remain at diurnal coverts or fly to different forested sites at night (Sepik and Derleth 1993). However, females frequently move to forest openings at night during July (Sepik and Derleth 1993). We were not able to determine the regularity with which female woodcock fly to forest openings at night in Rhode Island because of the difficulty associated with catching females (McAuley et al. 1993). Nonetheless, moving to forest openings at night during summer must provide some benefit to both males and females, especially during periods when this behavior is prevalent. 


\section{Testing hypotheses about the trade-offs between foraging and predation risk in}

ecological systems: insights provided by commuting behavior.

Organisms that move between sites within each day (i.e., those that commute) provide behavioral ecologists unique opportunities to investigate the trade-offs between foraging and predation risk for individuals within a relevant ecological context. We have shown that the decision by woodcock to move from diurnal coverts to nocturnal roost fields during summer may be advantageous because woodcock can acquire resources by day and better avoid predators at night. Temporal or spatial variation in foraging benefits and predation risk should be required if prey are to use commuting behavior to best balance the trade-offs between feeding and avoiding predators (Duriez et al. 2005; Bednekoff and Lima 2011). In our case, woodcock remaining at diurnal coverts throughout the night could conserve energy compared to other birds that commute, although the energy savings may be modest (e.g., corvids; Sonerud et al. 2001; Wright et al. 2003). Perhaps more importantly, woodcock remaining at diurnal coverts throughout the night could exploit preferred foods (Wishart and Bider 1977; Sepik and Derleth 1993; this study). However, our data show that predation risk during the night is elevated at diurnal coverts compared to nocturnal roost fields. During periods of high risk, prey species are expected to allocate more time to antipredator behaviors and less time to feeding whereas feeding effort should be increased during periods of lower risk (Lima and Bednekoff 1999). Rather than remaining at diurnal coverts throughout the day and night, woodcock appear to balance the trade-off between feeding and avoiding predators by feeding at diurnal 
coverts during the day, a time when nocturnal mammalian predators are usually less active, and then moving to nocturnal roost fields at night.

Consistent movement by woodcock to forest openings at night during summer is influenced by the end of the breeding season, the independence of broods, and the postnuptial molt period (Sheldon 1967; Krohn 1971; Owen and Krohn 1973). Thus, during some nights, female woodcock may favor remaining at diurnal coverts, where preferred food availability is greatest, in order to rebuild energy reserves after reproducing (Sepik and Derleth 1993). Male woodcock do not produce eggs or rear young so their decision to move to forest openings at night during summer may be less influenced by such energetically expensive events (Sepik and Derleth 1993). On the other hand, male woodcock might remain at diurnal coverts to feed during some nights to help replenish energy reserves used during spring courtship flights. Importantly, male and female woodcock may elect to remain at diurnal coverts where they can feed efficiently at night in order to meet energy demands associated with postnuptial molt (Owen and Krohn 1973) or build fat stores prior to fall migration (Sepik and Derleth 1993). Indeed, state-dependent decision making is an anticipated part of risk allocation (Beauchamp and Ruxton 2011; Bednekoff and Lima 2011) and should be expected to cause varying patterns of antipredator behavior as prey attempt to optimize their respective trade-offs between feeding and avoiding predators. For woodcock, if feeding requirements can be met during the day, and if building energy reserves is not of concern, then individuals should favor flying to nocturnal roost fields at night during summer where they are safer from predators even though foraging opportunities are more limited. 
Animals living in complex environments where food availability and predation risk are variable should maximize fitness by adopting behaviors that balance trade-offs between finding food and becoming food (Lima and Bednekoff 1999; Higginson et al. 2012). Because prey allocate risk under schedules imposed by predators (Bednekoff and Lima 2011) understanding the timescale at which risk allocation occurs is an important step towards identifying behaviors employed to actively manage risk. In this study, we illustrate that woodcock experience periods of variable risk on a daily basis during summer months. Some species manage risk by increasing vigilance (Périquet et al. 2012) whereas others manage risk by moving between microhabitats where predators have limited access (Roberts and Liebgold 2008). Here, we show that some species can effectively reduce their risk of predation by moving between dissimilar vegetation types during the day and night. Consequently, maintaining forest openings is an important part of woodcock habitat management throughout the species summer range so that individuals have the option to fly between diurnal coverts and nocturnal roost fields where they can eat by day and stay safe by night.

\section{ACKNOWLEDGMENTS}

Funding for this project was provided in part by the Rhode Island Agricultural Experiment Station, the U.S. Department of Agriculture McIntyre-Stennis (MS-975) and Hatch (H-333) Grants, the Rhode Island Department of Environmental Management via USFWS Federal Aid to Wildlife Investigations Project W-23R, and the Department of Natural Resources Science at University of Rhode Island. We thank the many volunteers that helped capture woodcock along with T. Heywood, S. Camillieri, J. Veale, J. Travers, A. Padula, W. Shean, L. Barnard, D. Duffin, and D. 
McAuley for their assistance in the field. We also thank D. McAuley, G. Sonerud, and several anonymous reviewers for providing helpful comments on earlier versions of this manuscript. Finally, we thank C. Staines, J. Atoyan, and S. Alm for their assistance in the lab, and L. Gonzalez and P. Pooler for statistical advice. This is contribution number 5342 of the Rhode Island Agricultural Experiment Station.

\section{REFERENCES}

Agresti A. 2007. An introduction to categorical data analysis. 2nd ed. Hoboken, NJ: John Wiley and Sons.

Beauchamp G, Ruxton GD. 2011. A reassessment of the predation risk allocation hypothesis: a comment on Lima and Bednekoff. Am Nat. 177:143-146.

Bednekoff PA, Lima SL. 2011. Risk allocation is a general phenomenon: a reply to Beauchamp and Ruxton. Am Nat. 177:147-151.

Berger DD, Hamerstrom F. 1962. Protecting a trapping station from raptor predation. J Wildlife Manage. 26:203-206.

Bider JR. 1968. Animal activity in uncontrolled terrestrial communities as determined by a sand transect technique. Ecol Monogr. 38:269-308.

Blackman EB, Deperno CS, Heiniger RW, Krachey MJ, Moorman CE, Peterson MN. 2012. Effects of crop field characteristics on nocturnal winter use by American woodcock. J Wildlife Manage. 76:528-533.

Connors JI, Doerr PD. 1982. Woodcock use of agricultural fields in coastal North Carolina. Seventh woodcock symposium; 1980 Oct 28-30; University Park, PA. Washington, DC: US Fish and Wildlife Service. p. 139-147. 
Dangerfield JM. 1997. Abundance and diversity of soil macrofauna in northern

Botswana. J Trop Ecol. 13:527-538.

Derleth EL, Sepik GF. 1990. Summer-fall survival of American woodcock in Maine. J Wildlife Manage. 54:97-106.

Dessecker DR, McAuley DG. 2001. Importance of early successional habitat to ruffed grouse and American woodcock. Wildlife Soc B. 29:456-465.

Dias MP, Granadeiro JP, Lecoq M, Santos CD, Palmeirim JM. 2006. Distance to hightide roosts constrains the use of foraging areas by dunlins: implications for the management of estuarine wetlands. Biol Conserv. 131:446-452.

Dunford RD, Owen RB Jr. 1973. Summer behavior of immature radio-equipped woodcock in central Maine. J Wildlife Manage. 37:462-469.

Duriez O, Fritz H, Binet F, Tremblay Y, Ferrand Y. 2005. Individual activity rates in wintering Eurasian woodcocks: starvation versus predation risk trade-off? Anim Behav. 69:39-49.

Dwyer TJ, Sepik GF, Derleth EL, McAuley DG. 1988. Demographic characteristics of a Maine woodcock population and effects of habitat management. Washington, DC: US Fish and Wildlife Service.

Ferrari MCO, Elvidge CK, Jackson CD, Chivers DP, Brown GE. 2010. The responses of prey fish to temporal variation in predation risk: sensory habituation or risk assessment? Behav Ecol. 21:532-536.

Fuller MR, Mosher JA. 1981. Methods of detecting and counting raptors: a review. Stud Avian Biol-Ser. 6:235-246. 
Gardner W, Mulvey EP, Shaw EC. 1995. Regression analyses of counts and rates: Poisson, overdispersed Poisson, and negative binomial models. Psychol Bull. 118:392-404.

Gehring TM, Swihart RK. 2003. Body size, niche breadth, and ecologically scaled responses to habitat fragmentation: mammalian predators in an agricultural landscape. Biol Conserv. 109:283-295.

Glasgow LL. 1958. Contributions to the knowledge of the ecology of the American woodcock, Philohela minor, on the wintering range in Louisiana $[\mathrm{PhD}$ dissertation]. College Station: Texas A \& M University.

Gompper ME, Kays RW, Ray JC, Lapoint SD, Bogan DA, Cryan JR. 2006. A comparison of noninvasive techniques to survey carnivore communities in northeastern North America. Wildlife Soc B. 34:1142-1151.

Hendershot WH, Lalande H, Duquette M. 1993. Soil reaction and exchangeable acidity. In: Carter MR, editor. Soil sampling and methods for analysis. Ottawa, Canada: Canadian Society of Soil Science. p. 141-145.

Higginson AD, Fawcett TW, Trimmer PC, McNamara JM, Houston AI. 2012. Generalized optimal risk allocation: foraging and antipredator behavior in a fluctuating environment. Am Nat. 180:589-603.

Huang P, Sieving KE, St. Mary CM. 2012. Heterospecific information about predation risk influences exploratory behavior. Behav Ecol. 23:463-472.

Jost L. 2006. Entropy and diversity. Oikos. 113:363-375. 
Keppie DM, Whiting RM Jr. 1994. American woodcock (Scolopax minor). In: Poole A, editor. The birds of North America. Ithaca, NY: Cornell Lab of Ornithology. 100.

Krementz DG. 2000. Habitat management for wintering American woodcock in the southeastern United States. Proceedings of the ninth American woodcock symposium; 1997 Jan 26-28; Baton Rouge, LA. Laurel, MD: US Geological Survey. p. 50-54.

Krohn WB. 1970. Woodcock feeding habits as related to summer field usage in central Maine. J Wildlife Manage. 34:769-775.

Krohn WB. 1971. Some patterns of woodcock activities on Maine summer fields. Wilson Bull. 83:396-407.

Krohn WB, Rieffenberger JC, Ferrigno F. 1977. Fall migration of woodcock at Cape May, New Jersey. J Wildlife Manage. 41:104-111.

Lima SL. 1985. Maximizing feeding efficiency and minimizing time exposed to predators: a trade-off in the black-capped chickadee. Oecologia. 66:60-67.

Lima SL, Bednekoff PA. 1999. Temporal variation in danger drives antipredator behavior: the predation risk allocation hypothesis. Am Nat. 153:649-659.

Lima SL, Dill LM. 1990. Behavioral decisions made under the risk of predation: a review and prospectus. Can J Zool. 68:619-640.

Lima SL, Valone TJ, Caraco T. 1985. Foraging-efficiency-predation-risk trade-off in the grey squirrel. Anim Behav. 33:155-165.

Linhart SB, Knowlton FF. 1975. Determining the relative abundance of coyotes by scent station lines. Wildlife Soc B. 3:119-124. 
Longcore JR, McAuley DG, Sepik GF, Pendleton GW. 1996. Survival of breeding male American woodcock in Maine. Can J Zool. 74:2046-2054.

Longcore JR, McAuley DG, Sepik GF, Pendleton GW. 2000. Survival of female American woodcock breeding in Maine. Proceedings of the ninth American woodcock symposium; 1997 Jan 26-28; Baton Rouge, LA. Laurel, MD: US Geological Survey. p. 65-76.

Magurran AE. 2004. Measuring biological diversity. Malden, MA: Blackwell Publishing.

McAuley DG, Longcore JR, Clugston DA, Allen RB, Weik A, Williamson S, Dunn J, Palmer B, Evans K, Staats W, Sepik GF, Halteman W. 2005. Effects of hunting on survival of American woodcock in the Northeast. J Wildlife Manage. 69:15651577.

McAuley DG, Longcore JR, Sepik GF. 1993. Techniques for research into woodcocks: experiences and recommendations. Proceedings of the eighth American woodcock symposium; 1990 Nov; West Lafayette, IN. Washington, DC: US Fish and Wildlife Service. p. 5-11.

McAuley DG, Longcore JR, Sepik GF, Pendleton GW. 1996. Habitat characteristics of American woodcock nest sites on a managed area in Maine. J Wildlife Manage. 60:138-148.

Mendall HL, Aldous CM. 1943. The ecology and management of the American woodcock. Orono, ME: University of Maine.

Milinski M, Heller R. 1978. Influence of a predator on the optimal foraging behavior of sticklebacks (Gasterosteus aculeatus L.). Nature. 275:642-644. 
Ott RL, Longnecker M. 2010. An introduction to statistical methods and data analysis. 6th ed. Belmont, CA: Brooks/Cole.

Owen RB Jr, Krohn WB. 1973. Molt patterns and weight changes of the American woodcock. Wilson Bull. 85:31-41.

Owen RB Jr, Morgan JW. 1975. Summer behavior of adult radio-equipped woodcock in central Maine. J Wildlife Manage. 39:179-182.

Pedan A. 2011. Analysis of count data using the SAS system. Statistics, Data Analysis, and Data Mining. Available online at http://www2.sas.com/proceedings/sugi26/p247-26.pdf. Accessed 7 May 2011.

Périquet S, Todd-Jones L, Valeix M, Stapelkamp B, Elliot N, Wijers M, Pays O, Fortin D, Madzikanda H, Fritz H, Macdonald DW, Loveridge AJ. 2012. Influence of immediate predation risk by lions on the vigilance of prey of different body size. Behav Ecol. 23:970-976.

R Development Core Team. 2009. R: a language and environment for statistical computing. Vienna, Austria: R Foundation for Statistical Computing. Available online at http://www.R-project.org. Accessed 7 May 2011.

RIGIS. 2012. Forest Habitat. Rhode Island Geographic Information System Data Distribution System, Environmental Data Center. University of Rhode Island, Kingston. Accessed 21 January 2013. Available from: $<$ http://www.edc.uri.edu/rigis $>$.

Roberts AM, Liebgold EB. 2008. The effects of perceived mortality risk on habitat selection in a terrestrial salamander. Behav Ecol. 19:621-626. 
Rogers DI, Piersma T, Hassell CJ. 2006. Roost availability may constrain shorebird distribution: exploring the energetic costs of roosting and disturbance around a tropical bay. Biol Conserv. 133:225-235.

Rogers DT Jr, Dauber MA. 1977. Status of the red-shouldered hawk in Alabama. Alabama Birdlife. 25:19.

Rothley KD, Schmitz OJ, Cohon JL. 1997. Foraging to balance conflicting demands: novel insights from grasshoppers under predation risk. Behav Ecol. 8:551-559.

Šálek M, Kreisinger J, Sedláček F, Albrecht T. 2010. Do prey densities determine preferences of mammalian predators for habitat edges in an agricultural landscape? Landscape Urban Plan. 98:86-91.

SAS Institute Inc. 2008. SAS/STAT Version 9.2. Cary, NC: SAS Institute Inc.

Searle KR, Stokes CJ, Gordon IJ. 2008. When foraging and fear meet: using foraging hierarchies to inform assessments of landscapes of fear. Behav Ecol. 19:475-482.

Sepik GF, Derleth EL. 1993. Habitat use, home range size, and patterns of moves of the American woodcock in Maine. Proceedings of the eighth American woodcock symposium; 1990 Nov; West Lafayette, IN. Washington, DC: US Fish and Wildlife Service. p. 41-49.

Sheldon WG. 1961. Summer crepuscular flights of American woodcock in central Massachusetts. Wilson Bull. 73:126-139.

Sheldon WG. 1967. The book of the American woodcock. Amherst, MA: University of Massachusetts.

Sih A. 1980. Optimal behavior: can foragers balance two conflicting demands? Science. 210:1041-1043. 
Sonerud GA, Smedshaug CA, Bråthen Ø. 2001. Ignorant hooded crows follow knowledgeable roost-mates to food: support for the information centre hypothesis. P Roy Soc Lond B Bio. 268:827-831.

Straw JA Jr, Wakeley JS, Hudgins JE. 1986. A model for management of diurnal habitat for American woodcock in Pennsylvania. J Wildlife Manage. 50:378-383.

Stribling HL, Doerr PD. 1985. Nocturnal use of fields by American woodcock. J Wildlife Manage. 49:485-491.

Tilgar V, Moks K, Saag P. 2011. Predator-induced stress changes parental feeding behavior in pied flycatchers. Behav Ecol. 22:23-28.

Van Buskirk J, Müller C, Portmann A, Surbeck M. 2002. A test of the risk allocation hypothesis: tadpole responses to temporal change in predation risk. Behav Ecol. 13:526-530.

van Gils JA, Spaans B, Dekinga A, Piersma T. 2006. Foraging in a tidally structured environment by red knots (Calidris canutus): ideal, but not free. Ecology. 87:1189-1202.

Williamson SJ. 2010. American woodcock: habitat best management practices for the Northeast. Washington, DC: US Department of Agriculture.

Wishart RA, Bider JR. 1976. Habitat preferences of woodcock in southwestern Quebec. J Wildlife Manage. 40:523-531.

Wishart RA, Bider JR. 1977. Aspects of woodcock nocturnal activity in southwestern Quebec. Can Field Nat. 91:141-147.

Wright J, Stone RE, Brown N. 2003. Communal roosts as structured information centres in the raven, Corvus corax. J Amin Ecol. 72:1003-1014. 


\section{Figure 1}

Average differences in earthworm fresh and dry weight (a), median difference in the cumulative density of known prey (b), and average differences in richness and diversity of soil macrofauna (c) at the diurnal coverts and nocturnal roost fields of radio-marked American woodcock (2011: 17 males; 2012: 20 males and one female) during July-August in Rhode Island, USA. Positive bars indicate greater values at diurnal coverts. Negative bars indicate greater values at nocturnal roost fields. Whiskers represent $95 \%$ confidence intervals.

\section{Figure 2}

Difference in the number of nights that any mammalian predator visited a baited track station at the diurnal covert and nocturnal roost field for each of 11 radio-marked American woodcock males during September 2011 in Rhode Island, USA. Positive bars indicate more nights with a predator visit at diurnal coverts. Negative bars indicate more nights with a predator visit at nocturnal roost fields.

\section{Figure 3}

Difference in the number of days until initial predator visit at the diurnal covert and nocturnal roost field for each of 12 radio-marked American woodcock males during August 2012 in Rhode Island, USA. Positive bars indicate more days until initial predator visit at diurnal coverts. Negative bars indicate more days until initial predator visit at nocturnal roost fields. 
Table 1

Average density (no./ $\mathrm{m}^{2}$ ) of potential prey found in the soils at the diurnal coverts and nocturnal roost fields of 17 radiomarked American woodcock males during August 2011 in Rhode Island, USA

\begin{tabular}{|c|c|c|c|c|c|c|}
\hline \multirow{3}{*}{ Taxon } & \multirow{3}{*}{ Common name } & \multicolumn{2}{|c|}{$\begin{array}{l}\text { Average density } \\
\left(\text { no. } / \mathrm{m}^{2}\right)\end{array}$} & \multicolumn{2}{|c|}{$\begin{array}{c}\text { Test } \\
\text { statistic }^{\mathrm{a}}\end{array}$} & \multirow{3}{*}{$P$} \\
\hline & & Diurnal & Nocturnal & $\mathrm{V}$ & $t_{16}$ & \\
\hline & & coverts & roosts & & & \\
\hline Araneae & Spiders & 0.39 & 0.00 & 6.00 & --- & 0.15 \\
\hline Coleoptera & Beetles & 11.63 & 17.12 & --- & 0.96 & 0.35 \\
\hline Diplopoda & Millipedes & 6.40 & 0.13 & 78.00 & --- & $<0.01$ \\
\hline Diptera & True flies & 5.23 & 0.52 & 27.00 & --- & 0.22 \\
\hline Haplotaxida & Earthworms & 30.59 & 9.93 & --- & 2.14 & 0.02 \\
\hline Hymenoptera & Ants & 1.31 & 13.59 & 5.00 & --- & 0.04 \\
\hline Isopoda & Pillbugs & 0.78 & 0.00 & 10.00 & --- & 0.09 \\
\hline
\end{tabular}


Lepidoptera

Butterflies/Moths $\quad 0.13$

Stylommatophora

Slugs

0.52

0.52

0.00

3.00

3.00

$--\quad 0.23$

${ }^{\mathrm{a}}$ Wilcoxon signed-rank test $(\mathrm{V})$ or paired $t$-test $\left(t_{16}\right)$. 
Table 2

Average density $\left(\right.$ no. $\left./ \mathrm{m}^{2}\right)$ of potential prey found in the soils at the diurnal coverts and nocturnal roost fields of 21 radiomarked American woodcock (20 males and one female) during July-August 2012 in Rhode Island, USA

\begin{tabular}{|c|c|c|c|c|c|c|}
\hline \multirow{3}{*}{ Taxon } & \multirow{3}{*}{ Common name } & \multicolumn{2}{|c|}{$\begin{array}{l}\text { Average density } \\
\qquad\left(\text { no. } / \mathrm{m}^{2}\right)\end{array}$} & \multicolumn{2}{|c|}{$\begin{array}{c}\text { Test } \\
\text { statistic }^{\mathrm{a}}\end{array}$} & \multirow{3}{*}{$P$} \\
\hline & & \multirow{2}{*}{$\begin{array}{l}\text { Diurnal } \\
\text { coverts }\end{array}$} & \multirow{2}{*}{$\begin{array}{l}\text { Nocturnal } \\
\text { roosts }\end{array}$} & $\mathrm{V}$ & $t_{20}$ & \\
\hline & & & & & & \\
\hline Araneae & Spiders & 0.53 & 0.95 & 18.00 & --- & 0.33 \\
\hline Blattodea & Cockroaches & 0.00 & 0.11 & 0.00 & --- & 1.00 \\
\hline Caudata & Salamanders & 0.11 & 0.11 & 1.50 & --- & 1.00 \\
\hline Chilopoda & Centipedes & 0.00 & 0.21 & 0.00 & --- & 0.35 \\
\hline Coleoptera & Beetles & 5.18 & 14.71 & 26.00 & --- & 0.01 \\
\hline Dermaptera & Earwigs & 0.11 & 0.00 & 1.00 & --- & 1.00 \\
\hline
\end{tabular}




\begin{tabular}{|c|c|c|c|c|c|c|}
\hline Diplopoda & Millipedes & 3.60 & 1.38 & 70.50 & --- & 0.09 \\
\hline Diptera & True flies & 0.42 & 0.74 & 13.50 & --- & 0.28 \\
\hline Haplotaxida & Earthworms & 15.66 & 4.23 & --- & 2.52 & 0.01 \\
\hline Hemiptera & True bugs & 0.42 & 0.11 & 12.00 & --- & 0.23 \\
\hline Hymenoptera & Ants & 23.70 & 80.84 & 57.00 & --- & 0.22 \\
\hline Isopoda & Pillbugs & 2.65 & 0.32 & 60.00 & --- & 0.02 \\
\hline Lepidoptera & Butterflies/Moths & 0.00 & 0.11 & 0.00 & --- & 1.00 \\
\hline
\end{tabular}

${ }^{\mathrm{a}}$ Wilcoxon signed-rank test $(\mathrm{V})$ or paired $t$-test $\left(t_{20}\right)$. 
a)

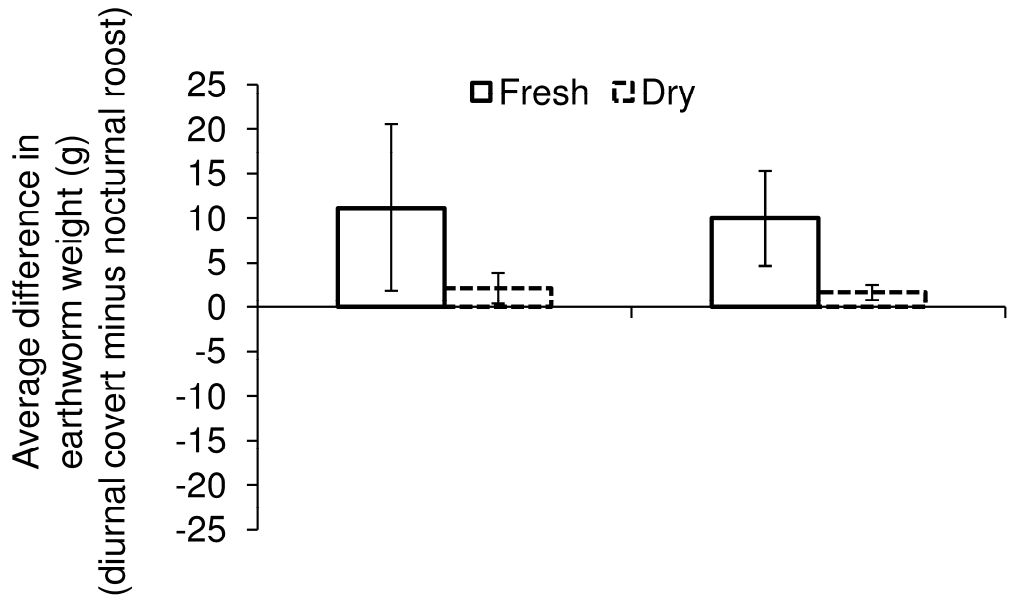

b)

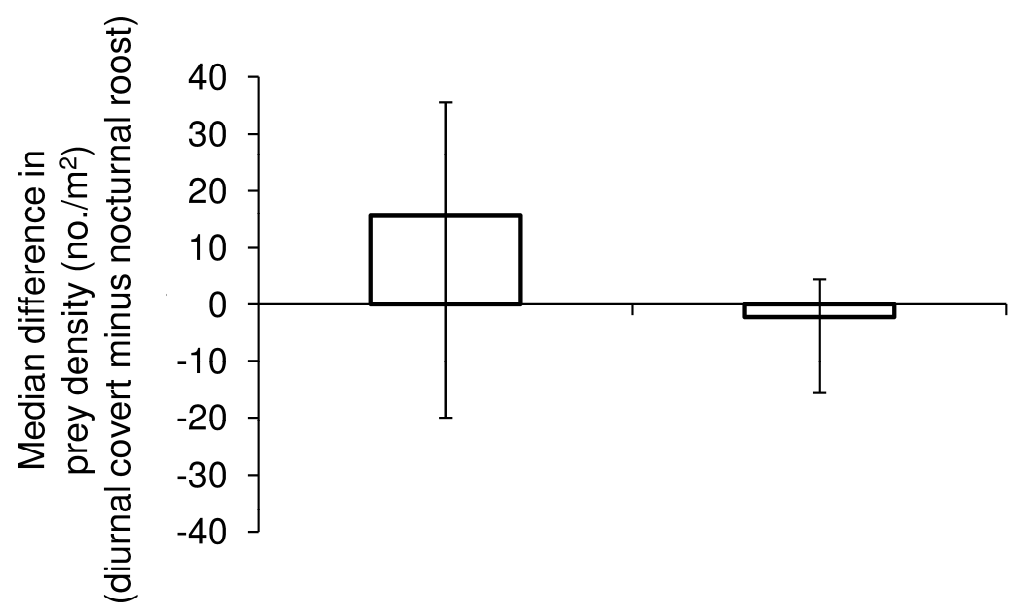

c)

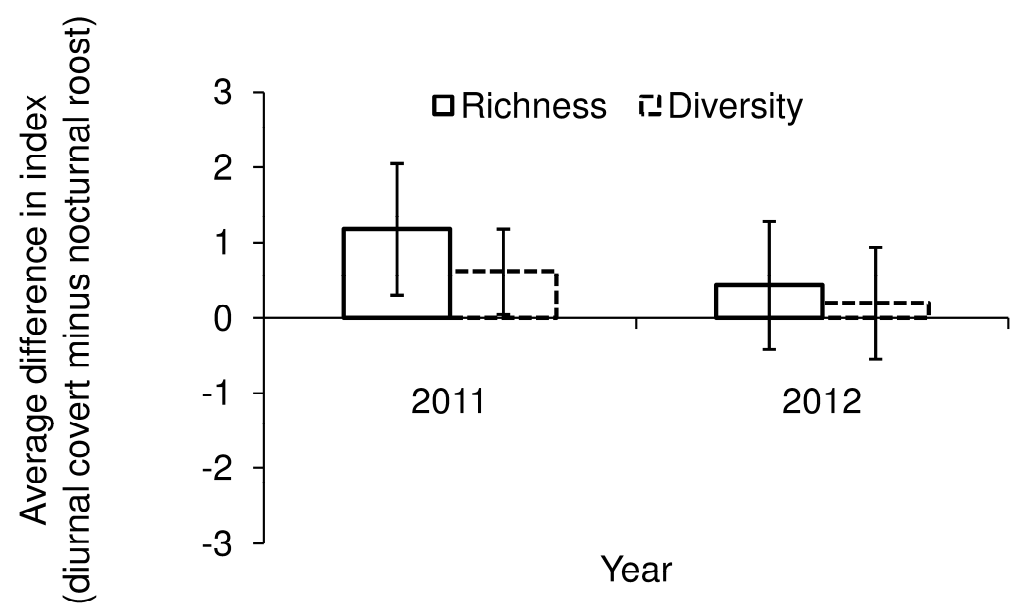

Figure 1 


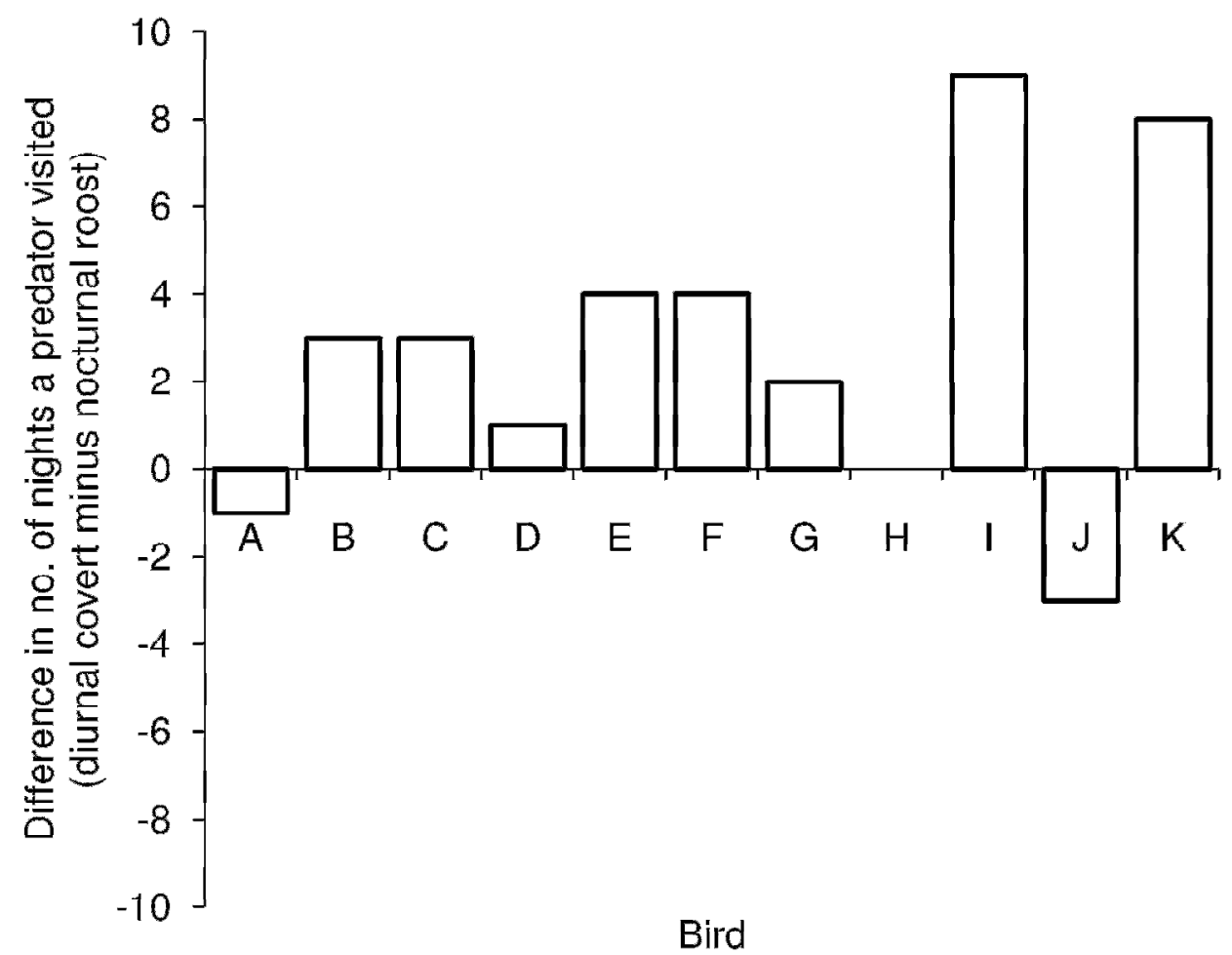

Figure 2 


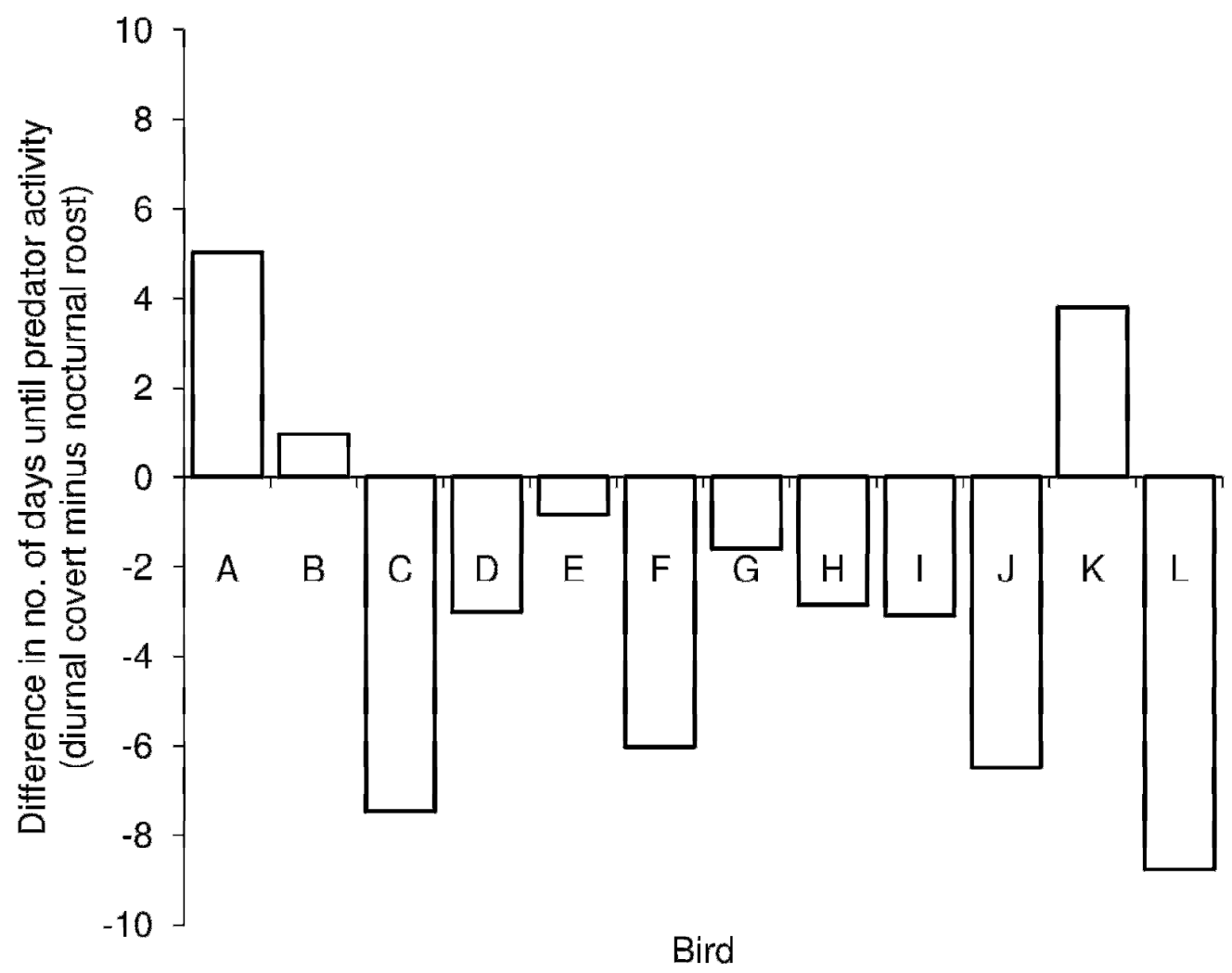

Figure 3 


\section{CHAPTER 3}

"Is American Woodcock Habitat Management for the Birds? Verifying the Woodcock as an Umbrella Species for Landbirds in the Northeast, USA"

by

Roger J. Masse ${ }^{1,3}$, Brian C. Tefft ${ }^{2}$, and Scott R. McWilliams ${ }^{1}$

is submitted to Biological Conservation

${ }^{1}$ Department of Natural Resources Science, University of Rhode Island, 102 Coastal Institute in Kingston, Kingston, RI 02881, USA.

${ }^{2}$ Rhode Island Department of Environmental Management, Division of Fish and Wildlife, 277 Great Neck Road, West Kingston, RI 02892, USA.

${ }^{3}$ Corresponding author; e-mail: rjmasse@my.uri.edu. 


\section{Abstract}

Young forest is an important vegetation type in the Northeast, USA, which has declined in extent during the past 60 years. Accordingly, populations of young forest wildlife have declined and forest management is required to conserve these species. Land managers often target conservation shortcuts (e.g., umbrella species) with hopes that non-target species benefit, but the effectiveness of these shortcuts is seldom verified. We compared landbird communities during summer at managed forest openings used by breeding American woodcock and nearby random forest sites to determine whether habitat management for woodcock benefits non-target landbirds. We used 50-m radius point counts to quantify the abundance and diversity of landbirds during summer at woodcock singing grounds and nearby random forest sites at three wildlife management areas in Rhode Island, USA. We identified 38 - 51 species at each management area and $62-73 \%$ of the more frequently occurring species were more common at woodcock singing grounds. Young forest species were more abundant at woodcock singing grounds and scarce or absent at random forest sites yet the opposite was true for mature forest species. The total number of birds (all species combined) and diversity of birds were $\geq 1.5$ times greater at woodcock singing grounds than random forest sites. Habitat management to conserve woodcock populations simultaneously benefits certain other non-target landbirds. Thus, the woodcock can serve as an effective umbrella species for young forest birds, but complementary umbrella species such as the ovenbird should be considered to aid in the conservation of bird species breeding in more mature forest. 


\section{Introduction}

Declines of early-successional forests and shrublands (hereafter young forest) and populations of associated wildlife are major conservation concerns in the Northeast, USA (Buffum et al., 2011; Dettmers, 2003; Litvaitis, 2001). Young forest is an important vegetation type that historically was maintained by natural and biological disturbances from wind and ice storms, fires, beavers (Castor canadensis), insect or pathogen outbreaks, and Native Americans (Askins, 2001; Day, 1953; Foster and Aber, 2004; Lorimer, 2001). From the late-1800's to mid-1900's, young forest expanded rapidly across the Northeast in response to widespread abandonment of farmlands that were initially converted from forest to agriculture by European settlers (Foster and Aber, 2004; Foster et al., 1998). However, the extent of young forest in the Northeast declined from highs of about $30-35 \%$ of the land area during the 1960's to $\leq 3 \%$ in some regions by the early- to mid-2000's (Buffum et al., 2011; Trani et al., 2001). Populations of young forest birds and mammals simultaneously declined since at least the 1960's (Dettmers, 2003; Litvaitis, 2001; Sauer et al., 2012). Given that former natural and biological disturbances are unable to maintain sufficient amounts of young forest on contemporary landscapes, conservation planning to support populations of young forest wildlife requires active forest management (DeGraaf and Yamasaki, 2003; Schlossberg and King, 2007).

Conservation planning that requires active habitat management is often complicated because not all species can be managed for simultaneously. Land managers must often set priorities with limited resources, and therefore, may target conservation shortcuts such as indicator, flagship, keystone, focal, or umbrella species 
to maximize conservation benefits (Lambeck, 1997; Niemi et al., 1997; Noss, 1990; Simberloff, 1998). Umbrella species are usually depicted as large-bodied, wideranging species with vast area requirements (Caro and O'Doherty, 1999; Noss, 1990) although they seldom fit a single description (Fleishman et al., 2000). More generally, umbrella species are simply those whose conservation works to conserve populations of sympatric non-target wildlife (Fleishman et al., 2000). However, the effectiveness of managing for umbrella species has been debated (Andelman and Fagan, 2000; Sattler et al., 2013; Simberloff, 1998; Suter et al., 2002) because managing for some putative umbrella species (e.g., capercaillie [Tetrao urogallus] and Siberian flying squirrel [Pteromys volans]; Hurme et al., 2008; Pakkala et al., 2003; Suter et al., 2002) effectively enhances diversity and abundance of non-target species while managing for others (e.g., California gnatcatcher [Polioptila californica] and greater sage-grouse [Centrocercus urophasianus]; Rowland et al., 2006; Rubinoff, 2001) may not be as effective. Habitat specialists may be best suited to serve as umbrella species, but ubiquity (or rarity), sensitivity to disturbance, and ease of monitoring should also be considered when identifying potential umbrella species (Andelman and Fagan, 2000; Caro and O'Doherty, 1999; Fleishman et al., 2000). Importantly, the co-occurrence of diverse non-target species is a necessary criterion for an effective umbrella species (Fleishman et al., 2000). Consequently, we investigated one of these criteria, the cooccurrence of non-target landbirds, with managed forest openings used by breeding American woodcock (Scolopax minor) to help verify the status of this bird as an umbrella species. 
The American woodcock (hereafter woodcock), a 116 - 279-g migratory upland shorebird, might represent an especially effective umbrella species because woodcock populations require a mixture of young forest ranging from forest openings to 30 -yearold forest stands (Kelley et al., 2008). Forest openings such as recently managed clearcuts, maintained or abandoned agricultural fields, and wildlife openings composed of scattered shrubs and trees provide necessary singing grounds during spring where males engage in crepuscular courtship displays to attract females for breeding (Sheldon, 1967). Similar forest openings also provide safe nocturnal roost sites during summer (Dunford and Owen, 1973; Masse et al., 2013) and nocturnal feeding or roosting sites during fall and winter (Blackman et al., 2012; Connors and Doerr, 1982; Krohn et al., 1977). In contrast, regenerating forest stands from $2-30$ years old provide nesting and brood rearing habitat for females and daytime cover for both sexes (Kelley et al., 2008). High densities of sapling or small tree stems typical of young forest protect woodcock from diurnal predators (Dessecker and McAuley, 2001; Keppie and Whiting, 1994; McAuley et al., 1996; Straw et al., 1986), but once regenerating forests are $>30$ years old they become less suitable (Kelley et al., 2008). Importantly, woodcock populations decline without the appropriate spectrum and spatial configuration of young forest (Dessecker and McAuley, 2001; McAuley et al., 2005; Williamson, 2010).

In this study, we compared landbird communities at managed forest openings used by breeding woodcock (i.e., woodcock singing grounds) to those at nearby random forest sites. Woodcock singing grounds typically comprise forest openings $>0.2$ ha with areas of low herbaceous ground cover and scattered shrubs or small trees 
(Williamson, 2010). Our objectives were to 1) determine the composition of the breeding bird communities, and 2) compare the abundance and diversity of breeding birds at woodcock singing grounds and nearby random forest sites. If woodcock represent an effective umbrella species then we predict that non-target young forest birds occur more frequently and are more abundant at woodcock singing grounds, and the overall number and diversity of birds is greater at these managed forest openings.

\section{Methods}

\subsection{Study area}

We conducted this study at three forest-dominated wildlife management areas (Arcadia, Great Swamp, and Big River) in Kent and Washington Counties, Rhode Island, USA. Arcadia $\left(41^{\circ} 35^{\prime} 10^{\prime \prime} \mathrm{N}, 71^{\circ} 43^{\prime} 20^{\prime \prime} \mathrm{W}\right)$ was $62 \mathrm{~km}^{2}$ comprised of relatively even proportions of coniferous (24\%), mixed (31\%), and deciduous upland forests (33\%) while wetland forests (7\%) were uncommon; Great Swamp (41 $27^{\circ} 15^{\prime \prime} \mathrm{N}$, $\left.71^{\circ} 35^{\prime} 19^{\prime \prime} \mathrm{W}\right)$ was $15 \mathrm{~km}^{2}$ of which coniferous (1\%), mixed (5\%), and deciduous upland forests (16\%) were less common while wetland forests $(55 \%)$ predominated; and Big River $\left(41^{\circ} 37^{\prime} 0^{\prime \prime} \mathrm{N}, 71^{\circ} 36^{\prime} 60^{\prime \prime} \mathrm{W}\right)$ was $33 \mathrm{~km}^{2}$ dominated by coniferous $(45 \%)$ and mixed upland forests (31\%) while deciduous upland forests (8\%) and wetland forests (6\%) were infrequent (RIGIS, 2012). Coniferous upland forests in the region were dominated by eastern white pine (Pinus strobus) or a mix of eastern white pine and pitch pine (Pinus rigida), mixed upland forests typically contained these species along with various oaks (Quercus spp.), and deciduous upland forests were dominated by red maple (Acer rubrum), hickories (Carya spp.), and oaks (Enser and Lundgren, 
2006). Red maple swamps were the typical wetland forest type in the region (Enser and Lundgren, 2006).

At each site, the Rhode Island Department of Environmental Management has maintained herbaceous forest openings and patches of young forest by periodically clearcutting areas of older secondary upland forest (e.g., 40 - 100 years old) in order to conserve populations of woodcock and other young forest wildlife. A series of $2-$ 5-ha clearcuts were first managed at Great Swamp, Arcadia, and Big River during 1995, 1996, and 2006, respectively. Managed clearcuts initially provide woodcock necessary singing grounds during spring (Dessecker and McAuley, 2001; Sheldon, 1967) and roosting sites during summer (Dunford and Owen, 1973; Masse et al., 2013), and also provide important nesting and diurnal cover as saplings, shrubs, and trees regenerate (Kelley et al., 2008; McAuley et al., 1996). During 2007, additional clearcuts were managed at Great Swamp and a long-term young forest management plan was adopted which, with support from the Wildlife Management Institute, helped designate a section of Great Swamp as a Woodcock Habitat Demonstration Area during 2008. Forest clearcuts were most recently managed at each site during 2012 and future cutting is expected to include larger (e.g., 10-ha) patches at more regular intervals (e.g., 5 - 10 years). Through 2020 , about 40 ha of the demonstration area at Great Swamp will be managed for young forest by clearcutting blocks of older secondary forest, and patches of young forest will be maintained at each site on a 30 40-year rotation. Given past habitat management, the proportion of young forest was highest at Great Swamp (15\%) followed by Arcadia (2\%) and Big River (1\%). 
Maintained or abandoned agricultural fields and other herb-dominated forest openings comprised $1-2 \%$ of each management area.

\subsection{Data collection}

We used standard 10-minute, 50-m radius point count surveys (Ralph et al., 1993) to determine the abundance and diversity of bird species at woodcock singing grounds and at randomly selected forest sites. We identified woodcock singing grounds from 2 April - 19 May at Arcadia and Great Swamp during 2011 - 2013 and at Big River during 2012 - 2013 as part of a separate study investigating woodcock habitat use in the region (Masse, 2014). During evening crepuscular periods, from sunset to ca. $1 \mathrm{hr}$ after sunset, 1 - 5 observers scouted sections of each management area by watching 2 -3 courtship flights of each displaying male woodcock and marking the exact locations of woodcock singing grounds with surveyor flagging (McAuley et al., 1993). Each spring, we identified 15 - 20 woodcock singing grounds at Arcadia, $10-13$ at Great Swamp, and 14 at Big River. Woodcock singing grounds were generally located in either 4 - 7-year-old clearcuts or wildlife openings with scattered shrubs and trees, but some were located in grasslands or near the margins of agricultural fields. Male woodcock conduct courtship displays to attract females for breeding so the quality of surrounding habitat for nesting and brood rearing (by females) likely influences singing ground use (Dessecker and McAuley, 2001). Consequently, some woodcock singing grounds at each site were clustered near one another in areas where nesting habitat was concentrated. For this study, we included a random subset of nine woodcock singing grounds at Arcadia and Great Swamp during 2011 and ten woodcock singing grounds at each site during 2012 - 2013 that were $\geq 200 \mathrm{~m}$ apart in 
order to promote independence. If the same woodcock singing grounds were used during successive years then we retained those locations in our sample and revisited them each year they were used. Otherwise, we randomly selected new woodcock singing grounds for inclusion provided they met our minimum distance criteria. From 2011 - 2013, we surveyed 15 different woodcock singing grounds at Arcadia (40\% sampled one year; $27 \%$ sampled two years; $33 \%$ sampled three years) and 13 different woodcock singing grounds at Great Swamp (23\% sampled one year; 31\% sampled two years; 46\% sampled three years). From 2012 - 2013, we surveyed 15 different woodcock singing grounds at Big River (67\% sampled one year; $33 \%$ sampled two years). At each management area, we generated a simple random sample of ten forest points to survey that were $>200 \mathrm{~m}$ from each other and from known woodcock singing grounds using ArcGIS 10.1 (Environmental Systems Research Institute, Redlands, CA) and revisited these locations each year.

From 27 May - 2 July, we conducted one point count per year at each woodcock singing ground and random forest site. In order to eliminate potential bias from differences in observer ability (Alldredge et al., 2007), the same experienced observer conducted all surveys from 0510 - 1045 (EST) during mornings with calm wind and no rain. We navigated to point count locations on foot using a handheld GPS unit and conducted $4-6$ surveys during a given morning. We alternated the timing of point counts at woodcock singing grounds and random forest sites to ensure that surveys at both treatment types were conducted at various times throughout the morning period. We identified bird species and counted the number of individuals seen or heard within 
$50 \mathrm{~m}$ of each point count location and excluded 'fly-by' species that were observed above the height of the surrounding canopy.

\subsection{Statistical analysis}

We calculated the frequency of occurrence and relative abundance for each species across point counts at each of the three sites and for each year. We also summarized data from each point count location in two separate ways. First, we calculated the total number of birds (all species combined). Second, we estimated the diversity of birds by calculating the Shannon-Weiner Index ( $\mathrm{H}^{\prime}$; Magurran, 2004) and converting to Diversity (D; Jost, 2006). We used a mixed model to test the main effects of location (i.e., woodcock singing ground vs. random forest), site, year, and all interactions on the number and diversity of birds. Interactions that were not significant $(P>0.05)$ were subsequently dropped from the model. We specified a random intercept corresponding to individual point count locations to account for the repeated structure of our data and we used the Gauss-Hermite quadrature approximation method to obtain maximum likelihood estimation (SAS, 2011; PROC GLIMMIX). We assumed a normal distribution because Shapiro-Wilk tests (Shapiro and Wilk, 1965) and normal probability plots suggested that the number and diversity of birds were normally distributed, and we adjusted for multiple comparisons using the Tukey-Kramer method (Kramer, 1956). For each dependent variable, we ran a separate model for Arcadia and Great Swamp during 2011 - 2013 and for all sites during 2012 - 2013 because the former provided us the strongest test for annual differences while the latter provided us the strongest test for site differences. 
We used sample-based rarefaction (Colwell et al., 2004) to generate species accumulation curves for woodcock singing grounds and random forest sites at each management area. Woodcock singing grounds that were surveyed during only one year were automatically included in this analysis. For woodcock singing grounds that were surveyed during 2 - 3 years, we randomly selected one year to include so that each point count location in this analysis was represented by equal sampling effort. Likewise, we randomly selected one year to include for each random forest site. We used the program EstimateS 9.1.0 (Colwell, 2013) to extrapolate rarefaction curves to 20 point count surveys and assessed differences in the expected number of species by examining the overlap of $95 \%$ confidence intervals (Colwell et al., 2012).

\section{Results}

We documented a total of 46 bird species at Arcadia, 38 at Big River, and 51 at Great Swamp (Table A.1). Nineteen species were unique to woodcock singing grounds and ten species were unique to random forest sites at both Arcadia and Big River, whereas 27 species were unique to woodcock singing grounds and 11 species were unique to random forest sites at Great Swamp. Most species were infrequent, but

the mean frequency of occurrence was $\geq 0.20$ for 11,15 , and 13 species at Arcadia, Big River, and Great Swamp, respectively; $62-73 \%$ of these species were more common at woodcock singing grounds. At Arcadia, 5 of 7 more common species at woodcock singing grounds and 3 of 4 more common species at random forest sites were either young forest species or species of high conservation priority (Table 1). At Big River, 7 of 11 more common species at woodcock singing grounds met these criteria compared to 1 of 4 more common species at random forest sites (Table 2). In contrast, at Great 
Swamp, nearly all more common species at woodcock singing grounds (7 of 8) and random forest sites (4 of 5) were young forest species or species of high conservation priority (Table 3). At each site, the relative abundances of the more common species at woodcock singing grounds and random forest sites were dissimilar (Table A.2).

Generally, young forest species such as prairie warbler (see Table A.1 for scientific names), gray catbird, and common yellowthroat were more abundant at woodcock singing grounds and scarce or absent at random forest sites while the opposite was true for more mature forest species such as ovenbird, veery, and red-eyed vireo (Fig. 1).

The total number (all species combined) and diversity of birds were highly correlated at each site $(r \geq 0.86)$. During $2011-2013$, the number of birds (mean $\pm \mathrm{SE}$ per 50-m plot) was $30 \%$ lower at Arcadia (4.70 \pm 0.38$)$ than Great Swamp (6.65 \pm $\left.0.38 ; \mathrm{F}_{1,68}=13.12, P<0.001\right)$ and, in general, about two times greater at woodcock singing grounds $(7.53 \pm 0.38)$ than random forest sites $\left(3.82 \pm 0.38 ; \mathrm{F}_{1,68}=47.40, P<\right.$ 0.001). The number of birds did not differ between years $\left(F_{2,68}=2.39, P=0.099\right)$ and we found no evidence for significant interactions $(P \geq 0.299)$. Likewise, bird diversity was $23 \%$ lower at Arcadia $(3.40 \pm 0.23)$ than Great Swamp $\left(4.42 \pm 0.23 ; \mathrm{F}_{1,68}=9.36\right.$, $P=0.003)$ and 1.6 times greater at woodcock singing grounds $(4.81 \pm 0.23)$ than random forest sites $\left(3.01 \pm 0.23 ; \mathrm{F}_{1,68}=29.63, P<0.001\right)$. Bird diversity did not differ between years $\left(\mathrm{F}_{2,68}=2.38, P=0.100\right)$ and we found no significant interactions $(P \geq$ $0.409)$.

During 2012 - 2013, the number of birds (mean \pm SE) was similar at Arcadia (5.15 $\pm 0.46)$ and Big River $(4.52 \pm 0.46 ; P=0.590)$, but at least 1.3 times greater at Great Swamp $(6.84 \pm 0.46 ; P \leq 0.033)$. The number of birds was $1.7-2.7$ times greater at 
woodcock singing grounds than random forest sites $(P \leq 0.007$; Fig. 2$)$ and we found no evidence for significant effects of year or interactions $(P \geq 0.149)$. Bird diversity was also similar at Arcadia $(3.63 \pm 0.28)$ and Big River $(3.21 \pm 0.28 ; P=0.546)$, but at least 1.3 times greater at Great Swamp (4.64 $\pm 0.28 ; P \leq 0.035)$. Bird diversity was $1.5-2.4$ times greater at woodcock singing grounds than random forest sites $(P \leq$ 0.036; Fig. 2) and we found no evidence for significant effects of year or interactions $(P \geq 0.489)$.

The cumulative numbers of species expected at woodcock singing grounds was always higher than random forest sites, but the $95 \%$ confidence intervals for these estimates overlapped at Arcadia and Big River. At Arcadia, the species accumulation curve for woodcock singing grounds approached an approximate asymptote at about 32 species while the curve for random forest sites began leveling off around 25 species (Fig. 3a). Similarly, the curves for woodcock singing grounds and random forest sites at Big River approached asymptotes at 29 and 23 species, respectively (Fig. 3b). In contrast, rarefaction curves at Great Swamp showed more divergence with approximate asymptotes of 38 species at woodcock singing grounds and 16 species at random forest sites (Fig. 3c).

\section{Discussion}

4.1. Bird communities differ between woodcock singing grounds and random forest sites

We found that bird communities at managed forest openings used by breeding woodcock were largely distinct from those at random forest sites. Most or all of the more frequently occurring species that were unique to woodcock singing grounds were 
young forest species whereas those unique to random forest sites were typically mature forest species (Tables $1-3$ ). However, at each management area, $2-3$ species (including $1-2$ young forest species) occurred at $\geq 1$ woodcock singing ground and random forest site each year. These species included cedar waxwing and red-eyed vireo at Arcadia (Table 1); black-capped chickadee, chipping sparrow, and eastern towhee at Big River (Table 2); and black-and-white warbler, American robin, and gray catbird at Great Swamp (Table 3). Forest generalists such as black-capped chickadee and red-eyed vireo were detected equally in clearcut stands (ca. $4-29$ years old) and forest reserves (ca. 85 - 140 years old) in New Hampshire, USA, whereas cedar waxwing, chipping sparrow, American robin, and black-and-white warbler were more common in managed stands (Welsh and Healy, 1993). Young forests occupy only 3\% of Rhode Island's land area (Buffum et al., 2011) and about $86 \%$ of the secondary forest in the state is ca. $40-100$ years old (Butler et al., 2012). Given insufficient habitat, some young forests species might select older, less optimal forests or specific forest types (e.g., wetland forests) which may provide similar young forest structure (e.g., American woodcock; Masse, 2014). While some young forest species occurred at $\geq 1$ woodcock singing ground and random forest site each year the relative abundances of these were nearly always higher at woodcock singing grounds (Fig. 1; Table A.2).

We also found some indication that landscape composition of forest cover types likely influences the composition of bird communities. Indeed, some species that were common at one management area were uncommon at others (Fig. 1). The composition of bird communities often differs between forest types (DeGraaf and Chadwick, 1987; 
Diaz, 2006; Sabo, 1980) or upland and riparian areas (Murray and Stauffer, 1995;

Palmer and Bennett, 2006). Arcadia was dominated by relatively equal proportions of coniferous, mixed, and deciduous upland forest whereas Big River was dominated by coniferous and mixed upland forest, and Great Swamp was dominated by wetland forest (Fig. 2a). Accordingly, species with an affinity to coniferous or mixed upland forests (e.g., chipping sparrow, prairie warbler, and pine warbler [Middleton, 1998; Nolan et al., 1999; Rodewald et al., 2013]) were more common at Arcadia or Big River. In contrast, species favoring dense undergrowth provided by wetland forests (e.g., veery, northern waterthrush, and black-and-white warbler [Bevier et al., 2005;

Golet et al., 2001; Kricher, 1995; Whitaker and Eaton, 2014]) were more abundant at Great Swamp. As a result, land managers should consider how the composition of forest cover types influences the composition of bird communities when setting conservation priorities during forest management planning.

4.2. The number and diversity of birds differ between woodcock singing grounds and random forest sites

We found that the total number (all species combined) and diversity of birds differed among the three study sites, but were always at least 1.5 times greater at managed forest openings used by breeding woodcock than at random forest sites (Fig. $2 b-c)$. In New York, USA, bird abundance and diversity were $>2$ times greater in 6year-old forest clearcuts than more mature even-aged stands (Keller et al., 2003) and bird diversity was greater in forests subjected to clearcutting than forest reserves in New Hampshire (Welsh and Healy, 1993). Forest clearcuts 3 - 12 years old also contained greater bird diversity than pole-sized or mature forests in Virginia, USA 
(Conner and Adkisson, 1975). Managing young forest for woodcock and other species necessarily results in the creation of habitat edges which often enhance wildlife diversity due to increased vegetative complexity or close proximity of disparate vegetation types (Johnston, 1947; Leopold, 1933; Yahner, 2000). Some edge effects (e.g., increased predation or brood parasitism) may be detrimental to forest birds in more agricultural landscapes (Donovan et al., 1997; Hoover et al., 2006), but in forestdominated regions of the Northeast these edge effects may have less of an impact (Rudnicky and Hunter, 1993; Yahner, 2000). Forest clearcuts and wildlife openings provide necessary habitat for young forest species (Chandler et al., 2009; King et al., 2009) and forest generalist or edge-species (this study) which further increases bird diversity at woodcock singing grounds.

Cumulative numbers of bird species expected at woodcock singing grounds and random forest sites were similar at Arcadia and Big River, but greater at woodcock singing grounds than random forest sites at Great Swamp (Fig. 3). Coniferous, mixed, and deciduous upland forests were more prevalent at Arcadia and Big River than Great Swamp (Fig. 2a) so the samples of random forest sites at each of those management areas contained a greater diversity of forest types. Since bird communities differ among forest types (DeGraaf and Chadwick, 1987; Diaz, 2006) it seems reasonable that similarities in the cumulative numbers of species expected at woodcock singing grounds and random forest sites at Arcadia and Big River were due, in part, to the fact that samples of random forest sites included several different forest types whereas samples of woodcock singing grounds included only young forest. Stratifying our samples of random forest sites by forest type would have allowed for more meaningful 
comparisons between woodcock singing grounds and specific secondary forest types, but this was not our intent. Even- and uneven-aged forest management practices represent complementary approaches to landbird conservation (Gram et al., 2003) and our findings that the cumulative numbers of expected species are similar (or greater) at managed forest openings used by breeding woodcock compared to random forest sites in some landscapes support this view.

\subsection{Are woodcock an effective umbrella species?}

Woodcock populations throughout the eastern USA have declined by $0.8-1.0 \%$ per year since 1968 (Cooper and Rau, 2013) as a result of young forest loss and degradation (Dessecker and McAuley, 2001; McAuley et al., 2005). Consequently, widespread, active forest management is required to conserve woodcock populations (Kelley et al., 2008). Clearcutting patches of older secondary forest is suggested as the most efficient method for increasing the extent of young forest (Dessecker and McAuley, 2001; McAuley et al., 1996; Williamson, 2010) and >22,000 $\mathrm{km}^{2}$ of young forest needs to be managed in the Northeast to meet woodcock population goals (Kelley et al., 2008). On the one hand, populations of many other young forest birds have also declined as a result of habitat loss and degradation and are therefore likely to benefit from such extensive young forest management (Brawn et al., 2001; DeGraaf and Yamasaki, 2003). Indeed, of the 22 young forest bird species that we observed, 55 $-77 \%$ occurred at woodcock singing grounds whereas only $14-32 \%$ occurred at random forest sites (Table A.1). On the other hand, populations of more mature forest species may decline in response to disturbances such as timber harvest (Gram et al., 2003; Wallendorf et al., 2007). Our results suggest that woodcock can serve as an 
umbrella species for the young forest bird assemblage in the Northeast. Moreover, detailed best management practices provide a specific prescription that public and private land managers can follow to improve woodcock habitat (Williamson, 2010) which further enhances the efficacy of woodcock to serve as a conservation shortcut.

In the Northeast, woodcock habitat can effectively be improved by creating a mosaic of $\geq 2$-ha clearcuts on about $25 \%$ of a 200 - 400-ha landscape (Williamson, 2010). Maintaining clearcuts on a 40 -year rotation provides the necessary spectrum of young forest for woodcock populations to thrive (McAuley et al., 1996; Williamson, 2010). The productivity and survival of young forest songbirds is typically not reduced in smaller patch sizes (Lehnen and Rodewald, 2009; Rodewald and Vitz, 2005), but clearcuts $>1-4$ ha are likely to be used by a greater proportion of young forest bird species (Schlossberg and King, 2007). Young forest birds are typically less common or absent in older secondary forest whereas mature forest birds generally avoid young forest during the breeding season (Keller et al., 2003; Wallendorf et al., 2007; Welsh and Healy, 1993). However, recent research suggests that patches of young forest provide important habitat for some mature forest species during the post-fledging period (Chandler et al. 2012; Marshall et al., 2003). Thus, maintaining some young forest on a given landscape should be viewed as a means to maximize biological conservation. We suggest that woodcock can serve as an effective umbrella species in the Northeast, especially for birds breeding in young forests, but complementary umbrella species such as the ovenbird should be considered to aid in the conservation of birds breeding in more mature forests. 


\section{Acknowledgments}

We thank T. Heywood, S. Camillieri, A. Hunt, A. Padula, W. Shean, L. Barnard, D. Duffin, and D. McAuley for their help in the field and A. Smith for advice regarding mixed modeling. We also thank B. Buffum and R. McKinney for helpful comments on an earlier version of this manuscript. Funding for this project was provided by the Rhode Island Department of Environmental Management via USFWS Federal Aid to Wildlife Investigations Project W-23R, the US Department of Agriculture McIntyre-Stennis (MS-975) and Hatch (H-333) grants, the Rhode Island Agricultural Experiment Station, and the Department of Natural Resources Science at University of Rhode Island. This is contribution number XXXX of the Rhode Island Agricultural Experiment Station.

\section{Appendix A. Supplementary material}

Supplementary data associated with this article can be found, in the online version, at XXXX.

\section{References}

Alldredge, M.W., Simons, T.R., Pollock, K.H., 2007. Factors affecting aural detections of songbirds. Ecol. Appl. 17, 948-955.

Andelman, S.J., Fagan, W.F., 2000. Umbrellas and flagships: efficient conservation surrogates or expensive mistakes? P. Natl. Acad. Sci. USA 97, 5954-5959.

Askins, R.A., 2001. Sustaining biological diversity in early successional communities: the challenge of managing unpopular habitats. Wildlife Soc. B. 29, 407-412. 
Bevier, L.R., Poole, A.F., Moskoff, W., 2005. Veery (Catharus fuscescens), in: Poole, A. (Ed.), The Birds of North America. Cornell Lab of Ornithology, Ithaca, New York.

Blackman, E.B., Deperno, C.S., Heiniger, R.W., Krachey, M.J., Moorman, C.E., Peterson, M.N., 2012. Effects of crop field characteristics on nocturnal winter use by American woodcock. J. Wildlife Manage. 76, 528-533.

Brawn, J.D., Robinson, S.K., Thompson, III, F.R., 2001. The role of disturbance in the ecology and conservation of birds. Annu. Rev. Ecol. Syst. 32, 251-276.

Buffum, B., McWilliams, S.R., August, P.V., 2011. A spatial analysis of forest management and its contribution to maintaining the extent of shrubland habitat in southern New England, United States. For. Ecol. Manage. 262, 1775-1785.

Butler, B.J., Morin, R.S., Nelson, M.D., 2012. Rhode Island's Forest Resources, 2011. Research Note NRS-151, US Department of Agriculture, Forest Service, Northern Research Station. Newtown Square, Pennsylvania. Accessed 13 December 2013. Available from:

< http://www.nrs.fs.fed.us/pubs/rn/rn_nrs151.pdf>.

Caro, T.M., O’Doherty, G., 1999. On the use of surrogate species in conservation biology. Conserv. Biol. 13, 805-814.

Chandler, C.C., King, D.I., Chandler, R.B., 2012. Do mature forest birds prefer earlysuccessional habitat during the post-fledging period? For. Ecol. Manage. 264, 1-9.

Chandler, R.B., King, D.I., Chandler, C.C., 2009. Effects of management regime on the abundance and nest survival of shrubland birds in wildlife openings in northern New England, USA. For. Ecol. Manage. 258, 1669-1676. 
Colwell, R.K., 2013. EstimateS: statistical estimation of species richness and shared species from samples. Version 9. Accessed 8 January 2014. Available from: $<$ purl.oclc.org/estimates $>$.

Colwell, R.K., Chao, A., Gotelli, N.J., Lin, S-Y., Mao, C.X., Chazdon, R.L., Longino, J.T., 2012. Models and estimators linking individual-based and sample-based rarefaction, extrapolation and comparison of assemblages. J. Plant Ecol. 5, 3-21.

Colwell, R.K., Mao, C.X., Chang, J., 2004. Interpolating, extrapolating, and comparing incidence-based species accumulation curves. Ecology 85, 2717-2727.

Conner, R.N., Adkisson, C.S., 1975. Effects of clearcutting on the diversity of breeding birds. J. Forest. 73, 781-785.

Connors, J.I., Doerr, P.D., 1982. Woodcock use of agricultural fields in coastal North Carolina. Woodcock Ecology and Management: Papers from the Seventh Woodcock Symposium; 28 - 30 October 1980; University Park, Pennsylvania. US Fish and Wildlife Service, Wildlife Research Report 14. Washington, DC, pp. $139-147$.

Cooper, T.R., Rau, R.D., 2013. American Woodcock Population Status, 2013. U.S. Fish and Wildlife Service, Laurel, Maryland.

Day, G.M., 1953. The Indian as an ecological factor in the northeastern forest. Ecology 34, 329-346.

DeGraaf, R.M., Chadwick, N.L., 1987. Forest type, timber size class, and New England breeding birds. J. Wildlife Manage. 51, 212-217. 
DeGraaf, R.M., Yamasaki, M., 2003. Options for managing early-successional forest and shrubland bird habitats in the northeastern United States. For. Ecol. Manage. $185,179-191$.

Dessecker, D.R., McAuley, D.G., 2001. Importance of early successional habitat to ruffed grouse and American woodcock. Wildlife Soc. B. 29, 456-465.

Dettmers, R., 2003. Status and conservation of shrubland birds in the northeastern US. For. Ecol. Manage. 185, 81-93.

Dettmers, R., Rosenberg, K.V., 2000. Partners in Flight landbird conservation plan: physiographic area 9: southern New England, Version 1.0. Partners in Flight, Northeast Region, Ithaca, New York. Accessed 6 February 2014. Available from: < http://www.partnersinflight.org/bcps/plan/pl_09_10.pdf>.

Díaz, L., 2006. Influences of forest type and forest structure on bird communities in oak and pine woodlands in Spain. For. Ecol. Manage. 223, 54-65.

Donovan, T.M., Jones, P.W., Annand, E.M., Thompson, III, F.R., 1997. Variation in local-scale edge effects: mechanism and landscape context. Ecology 78, 20642075.

Dunford, R.D., Owen Jr., R.B., 1973. Summer behavior of immature radio-equipped woodcock in central Maine. J. Wildlife Manage. 37, 462-469.

Enser, R.W., Lundgren, J.A., 2006. Natural communities of Rhode Island. Rhode Island Natural History Survey, Kingston, Rhode Island. Accessed 19 October 2013. Available from: <http://rinhs.org/wpcontent/uploads/2012/05/ri_nat_comms_2006.pdf>. 
Fleishman, E., Murphy, D.D., Brussard, P.F., 2000. A new method for selection of umbrella species for conservation planning. Ecol. Appl. 10, 569-579.

Foster, D.R., Aber, J.D., 2004. Forests in Time: the Environmental Consequences of 1,000 years of Change in New England. Yale University Press, New Haven, Connecticut.

Foster, D.R., Motzkin, G., Slater, B., 1998. Land-use history as long-term broad-scale disturbance: regional forest dynamics in central New England. Ecosystems 1, 96119.

Golet, F.C., Wang, Y., Merrow, J.S., DeRagon, W.R., 2001. Relationship between habitat and landscape features and the avian community of red maple swamps in southern Rhode Island. Wilson Bull. 113, 217-227.

Gram, W.K., Porneluzi, P.A., Clawson, R.L., Faaborg, J., Richter, S.C., 2003. Effects of experimental forest management on density and nesting success of bird species in Missouri Ozark forests. Conserv. Biol. 17, 1324-1337.

Hoover, J.P., Tear, T.H., Baltz, M.E., 2006. Edge effects reduce the nesting success of Acadian flycatchers in a moderately fragmented forest. J. Field Ornithol. 77, 425436.

Hurme, E., Mönkkönen, M., Sippola, A-L., Ylinen, H., Pentinsaari, M., 2008. Role of the Siberian flying squirrel as an umbrella species bor biodiversity in northern boreal forests. Ecol. Indic. 8, 246-255.

Johnston, V.R., 1947. Breeding birds of the forest edge in Illinois. Condor 49, 45-53.

Jost, L., 2006. Entropy and diversity. Oikos 113, 363-375. 
Keller, J.K., Richmond, M.E., Smith, C.R., 2003. An explanation of patterns of breeding bird species richness and density following clearcutting in northeastern USA forests. For. Ecol. Manage. 174, 541-564.

Kelley, J., Williamson, S., Cooper, T.R. (Eds.), 2008. American Woodcock Conservation Plan: A Summary of and Recommendations for Woodcock Conservation in North America. Wildlife Management Institute. Accessed 19 October 2013. Available from: $<$ http://timberdoodle.org/sites/default/files/woodcockPlan_0.pdf>.

Keppie, D.M., Whiting Jr., R.M., 1994. American woodcock (Scolopax minor), in: Poole, A. (Ed.), The Birds of North America. Cornell Lab of Ornithology, Ithaca, New York.

King, D.I., Chandler, R.B., Schlossberg, S., Chandler, C.C., 2009. Habitat use and nest success of scrub-shrub birds in wildlife and silvicultural openings in western Massachusetts, USA. For. Ecol. Manage. 257, 421-426.

Kramer, C.Y., 1956. Extension of multiple range tests to group means with unequal numbers of replications. Biometrics 12, 307-310.

Kricher, J.C., 1995. Black-and-white warbler (Mniotilta varia), in: Poole, A. (Ed.), The Birds of North America. Cornell Lab of Ornithology, Ithaca, New York.

Krohn, W.B., Rieffenberger, J.C., Ferrigno, F., 1977. Fall migration of woodcock at Cape May, New Jersey. J. Wildlife Manage. 41, 104-111.

Lambeck, R.J., 1997. Focal species: a multi-species umbrella for nature conservation. Conserv. Biol. 11, 849-856. 
Lehnen, S.E., Rodewald, A.D., 2009. Investigating area-sensitivity in shrubland birds: responses to patch size in a forested landscape. For. Ecol. Manage. 257, 23082316.

Leopold, A., 1933. Game management. Charles Scribner's Sons, New York, New York.

Litvaitis, J.A., 2001. Importance of early successional habitats to mammals in eastern forests. Wildlife Soc. B. 29, 466-473.

Lorimer, C.G., 2001. Historical and ecological roles of disturbance in eastern North American forests: 9,000 years of change. Wildlife Soc. B. 29, 425-439.

Magurran, A.E., 2004. Measuring biological diversity. Blackwell Publishing, Malden, Massachusetts.

Marshall, M.R., DeCecco, J.A., Williams, A.B., Gale, G.A., Cooper, R.J., 2003. Use of regenerating clearcuts by late-successional bird species and their young during the post-fledging period. For. Ecol. Manage. 183, 127-135.

Masse, R.J., 2014. American woodcock ecology and bird conservation in relation to forest management. PhD Dissertation, University of Rhode Island, Kingston.

Masse, R.J., Tefft, B.C., Amador, J.A., McWilliams, S.R., 2013. Why woodcock commute: testing the foraging-benefit and predation-risk hypotheses. Behav. Ecol. $24,1348-1355$.

McAuley, D.G., Longcore, J.R., Clugston, D.A., Allen, R.B., Weik, A., Williamson, S., Dunn, J., Palmer, B., Evans, K., Staats, W., Sepik, G.F., Halteman, W., 2005. Effects of hunting on survival of American woodcock in the Northeast. J. Wildlife Manage. 69, 1565-1577. 
McAuley, D.G., Longcore, J.R., Sepik, G.F., 1993. Techniques for research into woodcock: experiences and recommendations. Proceedings of the Eighth American Woodcock Symposium; 29 October - 2 November 1990; West Lafayette, Indiana. US Fish and Wildlife Service, Biological Report 16. Washington, DC, pp. 5-11.

McAuley, D.G., Longcore, J.R., Sepik, G.F., Pendleton, G.W., 1996. Habitat characteristics of American woodcock nest sites on a managed area in Maine. J. Wildlife Manage. 60, 138-148.

Middleton, A.L., 1998. Chipping sparrow (Spizella passerina), in: Poole, A. (Ed.), The Birds of North America. Cornell Lab of Ornithology, Ithaca, New York.

Murray, N.L., Stauffer, F., 1995. Nongame bird use of habitat in central Appalachian riparian forests. J. Wildlife Manage. 59, 78-88.

Niemi, G.J., Hanowski, J.M., Lima, A.R., Nicholls, T., Weiland, N., 1997. A critical analysis on the use of indicator species in management. J. Wildlife Manage. 61, $1240-1252$.

Nolan, Jr., V., Ketterson, E.D., Buerkle, C.A., 1999. Prairie warbler (Setophaga discolor), in: Poole, A. (Ed.), The Birds of North America. Cornell Lab of Ornithology, Ithaca, New York.

Noss, R.F., 1990. Indicators for monitoring biodiversity: a hierarchical approach. Conserv. Biol. 4, 355-364.

Pakkala, T., Pellikka, J., Lindén, H., 2003. Capercaillie (Tetrao urogallus) - a good candidate for an umbrella species in taiga forests. Wildl. Biol. 9, 309-316. 
Palmer, G.C., Bennett, A.F., 2006. Riparian zones provide for distinct bird assemblages in forest mosaics of south-east Australia. Biol. Conserv. 130, 447457.

Ralph, C.J., Geupel, G.R., Pyle, P., Martin, T.E., DeSante, D.F., 1993. Handbook of field methods for monitoring landbirds. US Department of Agriculture, Forest Service, Pacific Southwest Research Station, General Technical Report PSWGTR-144-www. Albany, California.

RIDEM, 2005. Rhode Island's comprehensive wildlife conservation strategy. Division of Fish and Wildlife, State of Rhode Island Department of Environmental Management, Providence. Accessed 6 February 2014. Available from: <http://www.dem.ri.gov/programs/bnatres/fishwild/pdf/swgplan.pdf>.

RIGIS, 2012. Forest Habitat. Rhode Island Geographic Information System Data Distribution System, Environmental Data Center. University of Rhode Island, Kingston. Accessed 21 October 2013. Available from: $<$ http://www.edc.uri.edu/rigis $>$.

Rodewald, A.D., Vitz, A.C., 2005. Edge- and area-sensitivity of shrubland birds. J. Wildlife Manage. 69, 681-588.

Rodewald, P.G., Withgott, J.H., Smith, K.G., 2013. Pine warbler (Setophaga pinus), in: Poole, A. (Ed.), The Birds of North America. Cornell Lab of Ornithology, Ithaca, New York.

Rowland, M.M., Wisdom, M.J., Suring, L.H., Meinke, C.W., 2006. Greater sagegrouse as an umbrella species for sagebrush-associated vertebrates. Biol. Conserv. $129,323-335$. 
Rubinoff, D., 2001. Evaluating the California gnatcatcher as an umbrella species for conservation of southern California coastal sage scrub. Conserv. Biol. 15, 13741383.

Rudnicky, T.C., Hunter, Jr., M.L., 1993. Avian nest predation in clearcuts, forests, and edges in a forest-dominated landscape. J. Wildlife Manage. 57, 358-364.

Sabo, S.R., 1980. Niche and habitat relations in subalpine bird communities of the White Mountains of New Hampshire. Ecol. Monogr. 50, 241-259.

SAS, 2011. SAS/STAT 9.3 User's Guide. SAS Institute, Inc., Cary, North Carolina. Accessed 21 October 2013. Available from: $<h t t p: / / s u p p o r t . s a s . c o m / d o c u m e n t a t i o n />$.

Sattler, T., Pezzatti, G.B., Nobis, M.P., Obrist, M.K., Roth, T., Moretti, M., 2013. Selection of multiple umbrella species for functional and taxonomic diversity to represent urban biodiversity. Conserv. Biol. $<$ http://dx.doi.org/10.1111/cobi.12213>.

Sauer, J.R., Hines, J.E., Fallon, J.E., Pardieck, K.L., Ziolkowshi, Jr., D.J., Link, W.A., 2012. The North American Breeding Bird Survey, Results and Analysis 1966 2011. Version 07.03.2013. USGS Patuxent Wildlife Research Center, Laurel, Maryland.

Schlossberg, S., King, D.I., 2007. Ecology and Management of Scrub-shrub Birds in New England: A Comprehensive Review. Natural Resources Conservation Service, Resource Inventory and Assessment Division, Beltsville, Maryland. Shapiro, S.S., Wilk, M.B., 1965. An analysis of variance test for normality (complete samples). Biometrika 52, $591-611$. 
Sheldon, W.G., 1967. The Book of the American Woodcock. University of Massachusetts, Amherst.

Simberloff, D., 1998. Flagships, umbrellas, and keystones: is single-species management passé in the landscape era? Biol. Conserv. 83, 247-257.

Straw Jr., J.A., Wakeley, J.S., Hudgins, J.E., 1986. A model for management of diurnal habitat for American woodcock in Pennsylvania. J. Wildlife Manage. 50, 378-383.

Suter, W., Graf, R.F., Hess, R., 2002. Capercaillie (Tetrao urogallus) and avian biodiversity: testing the umbrella-species concept. Conserv. Biol. 16, 778-788.

Trani, M.K., Brooks, R.T., Schmidt, T.L., Rudis, V.A., Gabbard, C.M., 2001. Patterns and trends of early successional forests in the eastern United States. Wildlife Soc. B. $29,413-424$.

Wallendorf, M.J., Porneluzi, P.A., Gram, W.K., Clawson, R.L., Faaborg, J., 2007. Bird response to clear cutting in Missouri Ozark forests. J. Wildlife Manage. 71, 1899-1905.

Welsh, C.J.E., Healy, W.M., 1993. Effect of even-aged timber management on bird species diversity and composition in northern hardwoods of New Hampshire. Wildlife Soc. B. 21, 143-154.

Whitaker, D.M., Eaton, S.W., 2014. Northern waterthrush (Parkesia noveboracensis), in: Poole, A. (Ed.), The Birds of North America. Cornell Lab of Ornithology, Ithaca, New York. 
Williamson, S.J., 2010. American woodcock: habitat best management practices for the Northeast. Wildlife Insight 89, US Department of Agriculture, Natural Resources Conservation Service. Washington, DC.

Yahner, R.H., 2000. Eastern Deciduous Forest: Ecology and Wildlife Conservation, Second Edition. University of Minnesota Press, Minneapolis. 


\section{Fig. 1}

Relative abundances (mean no. of individuals per 50-m radius plot) for bird species observed with the three highest frequencies of occurrence during 10-minute point counts conducted at woodcock singing grounds and random forest sites from 27 May 2 July 2011 - 2013 at Arcadia (a), Big River (b), and Great Swamp (c) Wildlife Management Areas in Kent and Washington Counties, Rhode Island, USA. The highest frequencies of occurrence were identical for several species in secondary forests at Big River and so two additional species are represented. Whiskers represent 1 SE. Scientific names are provided in Table A.1.

\section{Fig. 2}

Proportions of forest cover types at Arcadia, Big River, and Great Swamp Wildlife Management Areas in Kent and Washington Counties, Rhode Island, USA (a). Mean number of birds (b) and diversity of birds (c) per 50-m plot at woodcock singing grounds and random forest sites based on 10-minute point counts conducted from 27 May - 2 July 2011 - 2013 at Arcadia and Great Swamp and 2012 - 2013 at Big River. Whiskers represent $95 \%$ confidence intervals.

\section{Fig. 3}

Sample-based rarefaction curves showing the cumulative number of species expected (solid lines) at woodcock singing grounds and random forest sites at Arcadia (a), Big River (b), and Great Swamp (c) Wildlife Management Areas in Kent and Washington Counties, Rhode Island, USA, based on 10-minute point counts conducted from 27 May - 2 July 2011 - 2013 at Arcadia and Great Swamp and 2012 - 2013 at Big River. Dashed lines represent $95 \%$ confidence intervals. 


\section{Table 1}

Bird species with a mean \pm SE frequency of occurrence $\geq 0.20$ at woodcock singing grounds or random forest sites based on 10 minute, 50-m radius point counts conducted from 27 May - 2 July 2011 - 2013 at Arcadia Wildlife Management Area in Kent and Washington Counties, Rhode Island, USA. Scientific names are provided in Table A.1.

\begin{tabular}{lcc}
\hline & \multicolumn{2}{c}{ Frequency of occurrence } \\
\cline { 2 - 3 } Common name & $0.55 \pm 0.09$ & Random forest sites \\
\cline { 2 - 3 } prairie warbler & Woodcock singing grounds & $0.00 \pm 0.00$ \\
chipping sparrow & $0.48 \pm 0.02$ & $0.03 \pm 0.03$ \\
cedar waxwing $^{1,3}$ & $0.44 \pm 0.11$ & $0.13 \pm 0.03$ \\
indigo bunting $^{1,3}$ & $0.38 \pm 0.09$ & $0.00 \pm 0.00$ \\
pine warbler $^{\text {eastern towhee }}$ & $0.37 \pm 0.17$ & $0.03 \pm 0.03$ \\
gray catbird $^{1,3}$ & $0.31 \pm 0.06$ & $0.03 \pm 0.03$ \\
red-eyed vireo $^{1,3}$ & $0.27 \pm 0.08$ & $0.03 \pm 0.03$ \\
& $0.13 \pm 0.07$ & $0.43 \pm 0.03$
\end{tabular}



ovenbird $^{3}$
$0.00 \pm 0.00$
$0.37 \pm 0.03$
black-and-white warbler ${ }^{1,2,3}$
$0.04 \pm 0.04$
$0.23 \pm 0.07$
scarlet tanager ${ }^{2,3}$
$0.00 \pm 0.00$
$0.20 \pm 0.06$

${ }^{1}$ Young forest species (Schlossberg and King 2007).

${ }^{2}$ High continental or regional priority in southern New England (Dettmers and Rosenberg 2000).

${ }^{3}$ Greatest conservation need in Rhode Island (RIDEM 2005). 


\section{Table 2}

Bird species with a mean \pm SE frequency of occurrence $\geq 0.20$ at woodcock singing grounds or random forest sites based on 10 minute, 50-m radius point counts conducted from 27 May - 2 July 2012 - 2013 at Big River Wildlife Management Area in Kent and Washington Counties, Rhode Island, USA. Scientific names are provided in Table A.1.

\begin{tabular}{lcc}
\hline & \multicolumn{2}{c}{ Frequency of occurrence } \\
Common name & $0.60 \pm 0.10$ & Random forest sites \\
\cline { 2 - 3 } gray catbird $^{1,3}$ & $0.50 \pm 0.00$ & $0.00 \pm 0.00$ \\
$\bar{\sigma} \quad$ prairie warbler $^{1,2,3}$ & $0.35 \pm 0.05$ & $0.00 \pm 0.00$ \\
common yellowthroat $^{1,3}$ & $0.30 \pm 0.10$ & $0.05 \pm 0.05$ \\
chipping sparrow $_{\text {eastern towhee }}^{1,2,3}$ & $0.30 \pm 0.00$ & $0.10 \pm 0.10$ \\
field sparrow & & \\
American robin & $0.30 \pm 0.10$ & $0.10 \pm 0.00$ \\
barn swallow & $0.25 \pm 0.05$ & $0.00 \pm 0.00$ \\
& $0.20 \pm 0.10$ & $0.00 \pm 0.00$
\end{tabular}




\begin{tabular}{lcc} 
cedar waxwing $^{1}$ & $0.20 \pm 0.20$ & $0.00 \pm 0.00$ \\
northern cardinal $^{1}$ & $0.20 \pm 0.10$ & $0.00 \pm 0.00$ \\
red-winged blackbird & $0.20 \pm 0.20$ & $0.00 \pm 0.00$ \\
pine warbler & $0.00 \pm 0.00$ & $0.30 \pm 0.00$ \\
black-capped chickadee & $0.10 \pm 0.10$ & $0.20 \pm 0.10$ \\
ovenbird $^{3}$ & $0.05 \pm 0.05$ & $0.20 \pm 0.00$ \\
veery & $0.00 \pm 0.00$ & $0.20 \pm 0.10$ \\
\hline
\end{tabular}

${ }^{1}$ Young forest species (Schlossberg and King 2007).

${ }^{2}$ High continental or regional priority in southern New England (Dettmers and Rosenberg 2000).

${ }^{3}$ Greatest conservation need in Rhode Island (RIDEM 2005). 


\section{Table 3}

Bird species with a mean \pm SE frequency of occurrence $\geq 0.20$ at woodcock singing grounds or random forest sites based on 10 minute, 50-m radius point counts conducted from 27 May - 2 July 2011 - 2013 at Great Swamp Wildlife Management Area in Washington County, Rhode Island, USA. Scientific names are provided in Table A.1.

\begin{tabular}{lcc}
\hline & \multicolumn{2}{c}{ Frequency of occurrence } \\
Common name & $0.83 \pm 0.06$ & Random forest sites \\
\cline { 2 - 3 } gray catbird $^{1,3}$ & Woodcock singing grounds & $0.27 \pm 0.09$ \\
$\vec{N}_{\infty}$ yellow warbler $^{1,3}$ & $0.72 \pm 0.09$ & $0.00 \pm 0.00$ \\
common yellowthroat $^{1,3}$ & $0.61 \pm 0.16$ & $0.07 \pm 0.07$ \\
blue-winged warbler $^{1,2,3}$ & $0.45 \pm 0.03$ & $0.00 \pm 0.00$ \\
eastern towhee $^{1,2,3}$ & $0.36 \pm 0.19$ & $0.00 \pm 0.00$ \\
American robin & $0.35 \pm 0.08$ & $0.13 \pm 0.03$ \\
cedar waxwing $^{1}$ & $0.34 \pm 0.09$ & $0.03 \pm 0.03$ \\
ruby-throated hummingbird $^{1}$ & $0.21 \pm 0.06$ & $0.07 \pm 0.07$
\end{tabular}


veery

northern waterthrush ${ }^{3}$

black-and-white warbler ${ }^{1,2,3}$

Canada warbler ${ }^{1,2,3}$

ovenbird $^{3}$
$0.03 \pm 0.03$

$0.00 \pm 0.00$

$0.10 \pm 0.10$

$0.00 \pm 0.00$

$0.00 \pm 0.00$
$0.60 \pm 0.10$

$0.47 \pm 0.07$

$0.33 \pm 0.07$

$0.27 \pm 0.03$

$0.20 \pm 0.08$

${ }^{1}$ Young forest species (Schlossberg and King 2007).

${ }^{2}$ High continental or regional priority in southern New England (Dettmers and Rosenberg 2000).

${ }^{3}$ Greatest conservation need in Rhode Island (RIDEM 2005). 

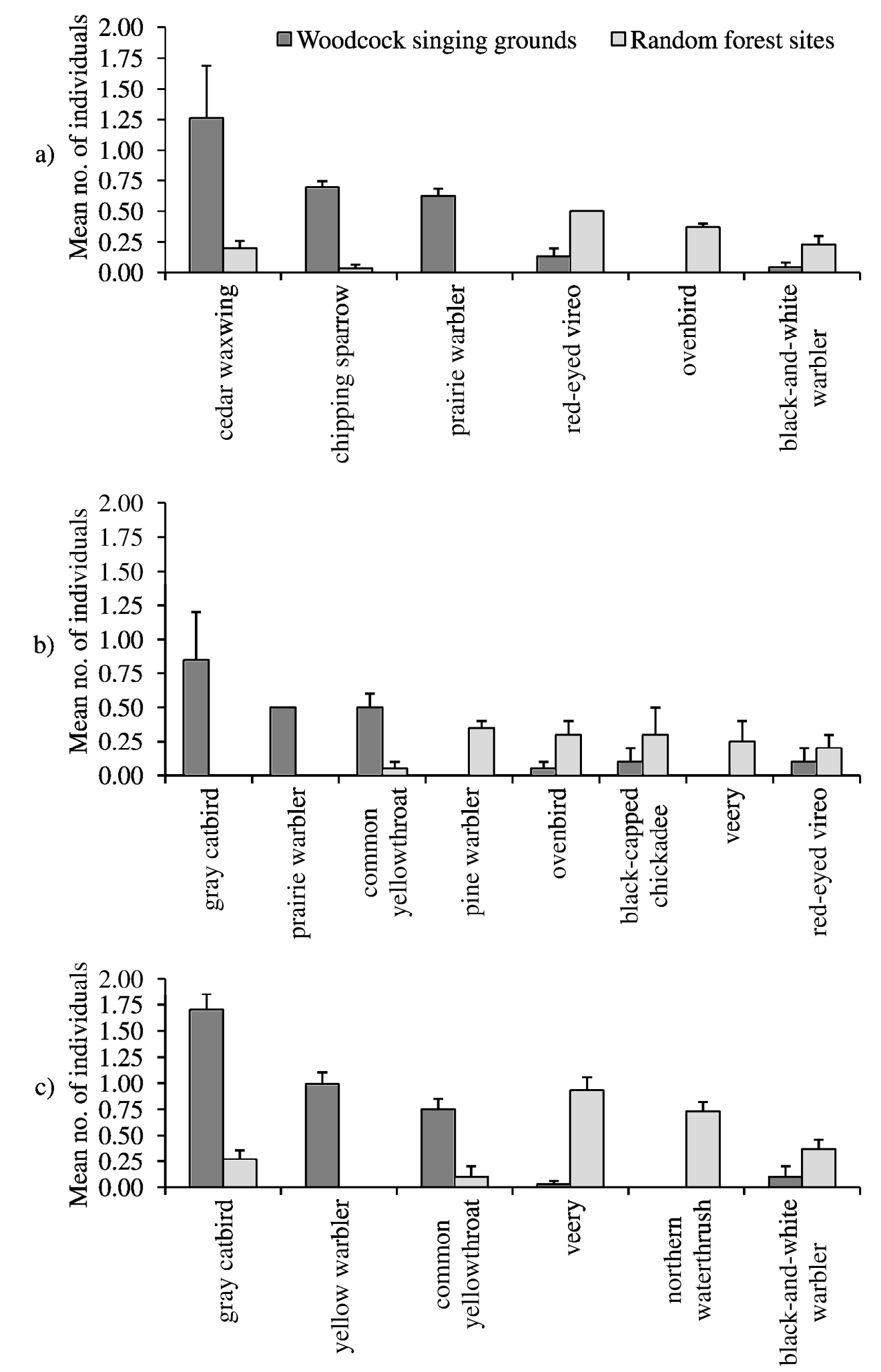

Species

Fig. 1 
$\square$ Coniferous upland forest $\square$ Mixed upland forest $\square$ Deciduous upland forest $\square$ Wetland forest

$\square$ Young forest

a)
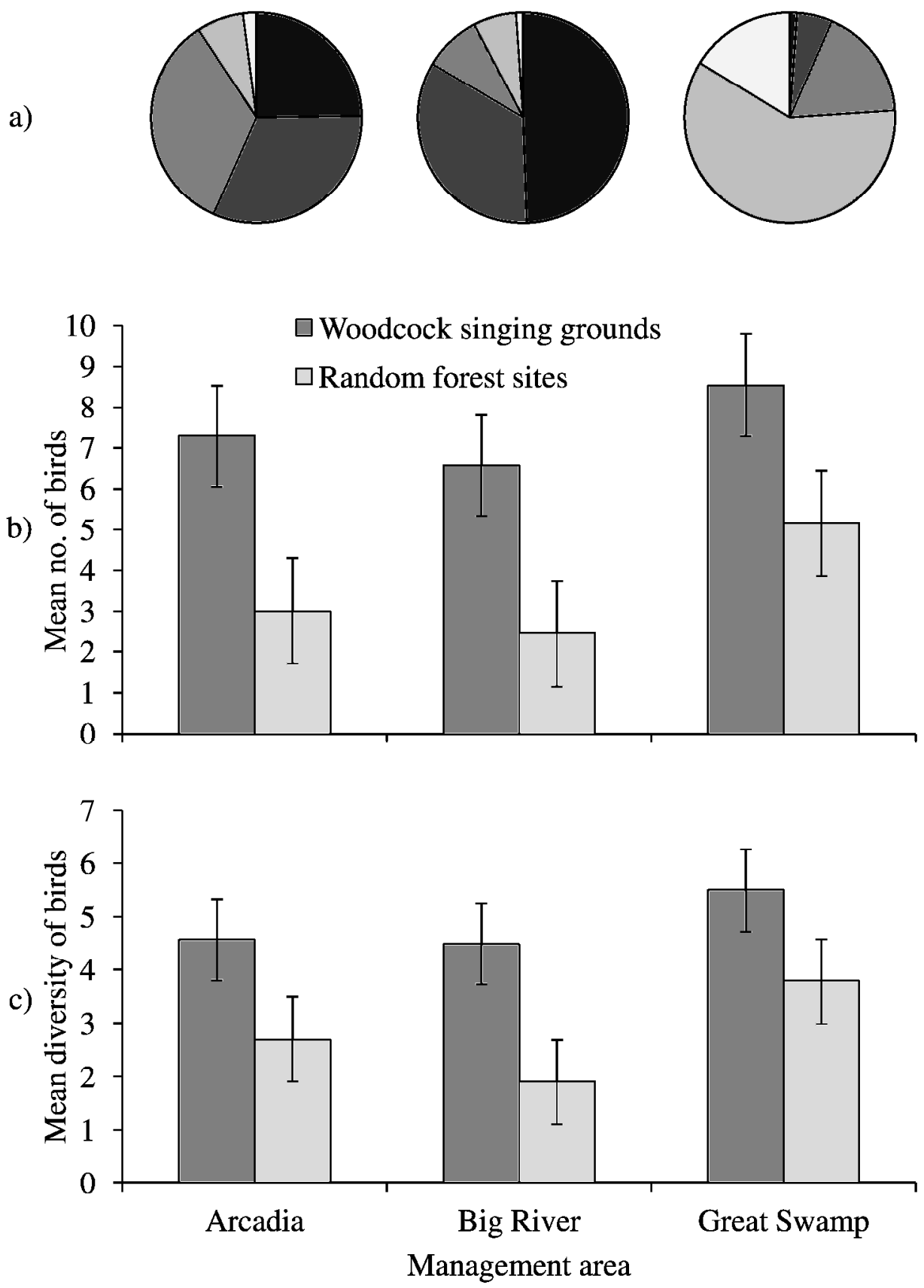

Fig. 2 

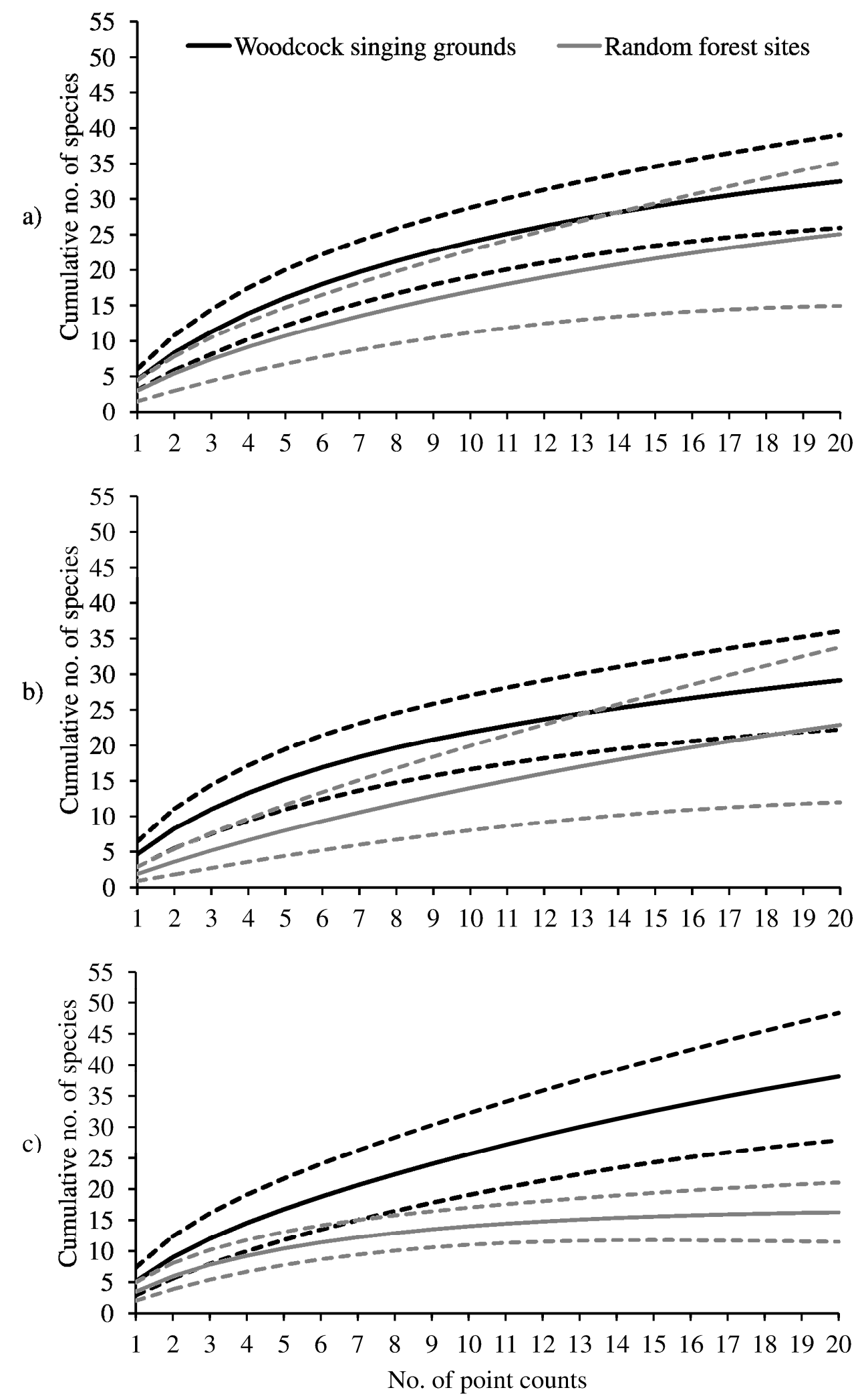

Fig. 3 


\section{Appendix A. Supplementary material.}

\section{Table A.1}

Common and scientific name, long-term population trend, and mean frequency of occurrence for bird species observed during 10-

minute, 50-m radius point count surveys at woodcock singing grounds and random forest sites from 27 May - 2 July $2011-2013$ at Arcadia and Great Swamp Wildlife Management Areas, and 2012 - 2013 at Big River Wildlife Management Area, in Kent and Washington Counties, Rhode Island, USA. Population trend (percent change per year) is based on the North American Breeding Bird Survey for the New England/Mid-Atlantic Coast Region (Sauer et al. 2012).

\begin{tabular}{|c|c|c|c|c|c|c|c|c|}
\hline & & \multirow[b]{2}{*}{ Pop. } & \multirow{2}{*}{\multicolumn{3}{|c|}{ Woodcock }} & \multirow{2}{*}{\multicolumn{3}{|c|}{ Random }} \\
\hline & \multirow{4}{*}{ Scientific name } & & & & & & & \\
\hline \multirow{3}{*}{ Common name } & & trend & \multicolumn{3}{|c|}{ singing grounds } & \multicolumn{3}{|c|}{ forest sites } \\
\hline & & $1966-$ & Arcadia & Big & Great & Arcadia & Big & Great \\
\hline & & 2011 & & River & Swamp & & River & Swamp \\
\hline American goldfinch $^{1}$ & Spinus tristis & 3.0 & 0.03 & 0.15 & 0.07 & 0.00 & 0.00 & 0.00 \\
\hline American redstart & Setophaga ruticilla & -0.4 & 0.00 & 0.10 & 0.10 & 0.00 & 0.00 & 0.03 \\
\hline
\end{tabular}




American robin
Baltimore oriole ${ }^{2,3}$
barn swallow
barred owl
black-and-white warbler ${ }^{1,2,3}$
black-capped chickadee
black-throated green warbler
blue jay
$\underset{+}{3}$
blue-gray gnatcatcher
blue-winged warbler
broad-winged hawk ${ }^{3}$
brown creeper

$\begin{array}{cccccccc}\text { Turdus migratorius } & -0.3 & 0.13 & 0.25 & 0.35 & 0.03 & 0.00 & 0.13 \\ \text { Icterus galbula } & -2.6 & 0.04 & 0.15 & 0.10 & 0.00 & 0.00 & 0.00 \\ \text { Hirundo rustica } & -1.2 & 0.00 & 0.20 & 0.00 & 0.00 & 0.00 & 0.00 \\ \quad \text { Strix varia } & 0.7 & 0.00 & 0.00 & 0.00 & 0.03 & 0.00 & 0.00 \\ \text { Mniotilta varia } & -3.2 & 0.04 & 0.05 & 0.10 & 0.23 & 0.10 & 0.33 \\ \text { Poecile atricapillus } & 0.2 & 0.17 & 0.10 & 0.03 & 0.13 & 0.20 & 0.17 \\ \text { Setophaga virens } & 0.4 & 0.00 & 0.00 & 0.00 & 0.00 & 0.00 & 0.13 \\ \text { Cyanocitta cristata } & -2.5 & 0.00 & 0.05 & 0.00 & 0.00 & 0.00 & 0.03 \\ \begin{array}{c}\text { Polioptila caerulea } \\ \text { Vermivora cyanoptera }\end{array} & 1.6 & 0.03 & 0.00 & 0.00 & 0.00 & 0.00 & 0.00 \\ \text { Buteo platypterus } & -2.4 & 0.07 & 0.00 & 0.45 & 0.00 & 0.00 & 0.00 \\ \text { Certhia americana } & -0.6 & 0.00 & 0.00 & 0.00 & 0.03 & 0.05 & 0.00 \\ \begin{array}{l}\text { Toxostoma rufum } \\ \text { Molothrus ater }\end{array} & -4.6 & 0.03 & 0.00 & 0.00 & 0.00 & 0.00 & 0.00\end{array}$




Canada warbler ${ }^{1,2,3}$
Carolina wren $^{1}$
cedar waxwing $^{1}$
chestnut-sided warbler ${ }^{1,3}$
chipping sparrow
common grackle
common yellowthroat
Cooper's hawk
downy woodpecker
eastern bluebird
eastern kingbird

$\begin{array}{cccccccc}\text { Cardellina canadensis } & -5.7 & 0.00 & 0.00 & 0.00 & 0.03 & 0.00 & 0.27 \\ \text { Thryothorus ludovicianus } & 3.1 & 0.03 & 0.05 & 0.00 & 0.00 & 0.00 & 0.00 \\ \text { Bombycilla cedrorum } & 4.1 & 0.44 & 0.20 & 0.34 & 0.13 & 0.00 & 0.03 \\ \text { Setophaga pensylvanica } & -2.8 & 0.00 & 0.00 & 0.03 & 0.00 & 0.00 & 0.00 \\ \text { Spizella passerina } & 0.3 & 0.48 & 0.30 & 0.04 & 0.03 & 0.10 & 0.00 \\ \text { Quiscalus quiscula } & -2.2 & 0.07 & 0.10 & 0.03 & 0.00 & 0.00 & 0.00 \\ \text { Geothlypis trichas } & -2.0 & 0.11 & 0.35 & 0.61 & 0.03 & 0.05 & 0.07 \\ \text { Accipiter cooperii } & 8.8 & 0.00 & 0.00 & 0.00 & 0.03 & 0.00 & 0.00 \\ \text { Picoides pubescens } & 0.8 & 0.03 & 0.00 & 0.14 & 0.03 & 0.05 & 0.00 \\ \quad \text { Sialia sialis } & 4.5 & 0.00 & 0.00 & 0.10 & 0.00 & 0.00 & 0.00 \\ \text { Tyrannus tyrannus } & -3.1 & 0.00 & 0.00 & 0.00 & 0.00 & 0.00 & 0.03 \\ \text { Sayornis phoebe } & -0.2 & 0.10 & 0.05 & 0.03 & 0.00 & 0.00 & 0.00 \\ \text { Pipilo erythrophthalmus } & -5.4 & 0.31 & 0.30 & 0.36 & 0.03 & 0.10 & 0.00 \\ \text { Contopus virens } & -0.5 & 0.00 & 0.00 & 0.00 & 0.17 & 0.05 & 0.00\end{array}$




\begin{tabular}{|c|c|c|c|c|c|c|c|c|}
\hline European starling & Sturnus vulgaris & -2.7 & 0.00 & 0.00 & 0.04 & 0.00 & 0.00 & 0.00 \\
\hline great crested flycatcher ${ }^{3}$ & Myiarchus crinitus & 0.2 & 0.03 & 0.00 & 0.03 & 0.03 & 0.00 & 0.17 \\
\hline hooded warbler ${ }^{3}$ & Setophaga citrina & -0.6 & 0.00 & 0.00 & 0.00 & 0.00 & 0.00 & 0.03 \\
\hline house finch & Haemorhous mexicanus & 5.2 & 0.00 & 0.00 & 0.03 & 0.00 & 0.00 & 0.00 \\
\hline house wren $^{1}$ & Troglodytes aedon & -0.9 & 0.04 & 0.00 & 0.03 & 0.00 & 0.00 & 0.00 \\
\hline northern cardinal $^{1}$ & Cardinalis cardinalis & 1.5 & 0.03 & 0.20 & 0.00 & 0.00 & 0.00 & 0.03 \\
\hline northern flicker ${ }^{3}$ & Colaptes auratus & -3.4 & 0.00 & 0.00 & 0.04 & 0.00 & 0.00 & 0.00 \\
\hline northern parula ${ }^{3}$ & Setophaga americana & 1.0 & 0.00 & 0.00 & 0.03 & 0.00 & 0.00 & 0.00 \\
\hline northern rough-winged swallow & Stelgidopteryx serripennis & 0.2 & 0.10 & 0.00 & 0.00 & 0.00 & 0.00 & 0.00 \\
\hline
\end{tabular}




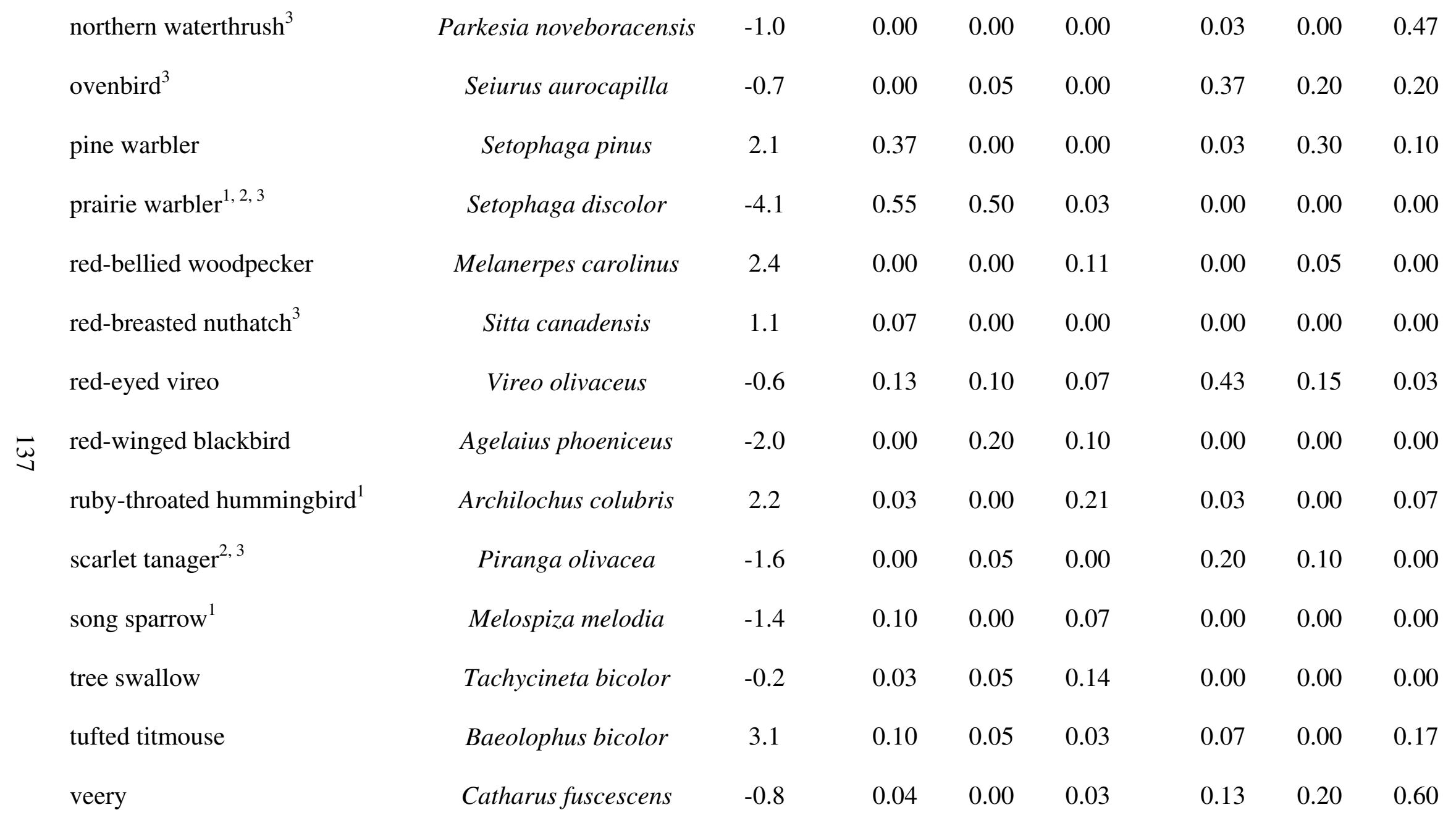




\begin{tabular}{|c|c|c|c|c|c|c|c|c|}
\hline white-breasted nuthatch & Sitta carolinensis & 2.6 & 0.03 & 0.00 & 0.00 & 0.17 & 0.05 & 0.00 \\
\hline white-eyed vireo $^{1}$ & Vireo griseus & -1.3 & 0.00 & 0.00 & 0.13 & 0.00 & 0.00 & 0.00 \\
\hline willow flycatcher ${ }^{1,3}$ & Empidonax traillii & 4.1 & 0.00 & 0.00 & 0.04 & 0.00 & 0.00 & 0.00 \\
\hline winter wren ${ }^{3}$ & Troglodytes hiemalis & -0.3 & 0.00 & 0.00 & 0.00 & 0.00 & 0.05 & 0.00 \\
\hline wood thrush ${ }^{2,3}$ & Hylocichla mustelina & -2.8 & 0.00 & 0.00 & 0.03 & 0.10 & 0.00 & 0.00 \\
\hline yellow warbler ${ }^{1,3}$ & Setophaga petechia & 0.4 & 0.03 & 0.15 & 0.72 & 0.00 & 0.00 & 0.00 \\
\hline yellow-billed cuckoo ${ }^{1,3}$ & Coccyzus americanus & -1.3 & 0.07 & 0.00 & 0.00 & 0.00 & 0.00 & 0.00 \\
\hline yellow-rumped warbler ${ }^{3}$ & Setophaga coronata & 1.0 & 0.00 & 0.00 & 0.00 & 0.00 & 0.05 & 0.00 \\
\hline yellow-throated vireo ${ }^{3}$ & Vireo flavifrons & -0.1 & 0.00 & 0.00 & 0.00 & 0.00 & 0.05 & 0.00 \\
\hline
\end{tabular}

\footnotetext{
${ }^{1}$ Young forest species (Schlossberg and King 2007).

${ }^{2}$ High continental or regional priority in southern New England (Dettmers and Rosenberg 2000).

${ }^{3}$ Greatest conservation need in Rhode Island (RIDEM 2005).
} 


\section{Table A.2}

Mean \pm SE relative abundance (no. of individuals per 50-m radius plot) for bird species observed during 10-minute point count surveys at woodcock singing grounds and random forest sites from 27 May - 2 July 2011 - 2013 at Arcadia and Great Swamp

Wildlife Management Areas, and 2012 - 2013 at Big River Wildlife Management Area, in Kent and Washington Counties, Rhode Island, USA.

\begin{tabular}{|c|c|c|c|c|c|c|}
\hline \multirow[b]{2}{*}{ Common name } & \multicolumn{3}{|c|}{ Woodcock singing grounds } & \multicolumn{3}{|c|}{ Random forest sites } \\
\hline & Arcadia & Big River & Great Swamp & Arcadia & Big River & Great Swamp \\
\hline American goldfinch $^{1}$ & $0.03 \pm 0.03$ & $0.15 \pm 0.05$ & $0.15 \pm 0.15$ & $0.00 \pm 0.00$ & $0.00 \pm 0.00$ & $0.00 \pm 0.00$ \\
\hline American redstart & $0.00 \pm 0.00$ & $0.10 \pm 0.10$ & $0.10 \pm 0.06$ & $0.00 \pm 0.00$ & $0.00 \pm 0.00$ & $0.03 \pm 0.03$ \\
\hline American robin & $0.20 \pm 0.12$ & $0.40 \pm 0.00$ & $0.45 \pm 0.05$ & $0.03 \pm 0.03$ & $0.00 \pm 0.00$ & $0.13 \pm 0.03$ \\
\hline Baltimore oriole ${ }^{2,3}$ & $0.04 \pm 0.04$ & $0.15 \pm 0.15$ & $0.10 \pm 0.06$ & $0.00 \pm 0.00$ & $0.00 \pm 0.00$ & $0.00 \pm 0.00$ \\
\hline barn swallow & $0.00 \pm 0.00$ & $0.20 \pm 0.10$ & $0.00 \pm 0.00$ & $0.00 \pm 0.00$ & $0.00 \pm 0.00$ & $0.00 \pm 0.00$ \\
\hline barred owl ${ }^{3}$ & $0.00 \pm 0.00$ & $0.00 \pm 0.00$ & $0.00 \pm 0.00$ & $0.03 \pm 0.03$ & $0.00 \pm 0.00$ & $0.00 \pm 0.00$ \\
\hline black-and-white warbler ${ }^{1,2,3}$ & $0.04 \pm 0.04$ & $0.05 \pm 0.05$ & $0.10 \pm 0.10$ & $0.23 \pm 0.07$ & $0.10 \pm 0.00$ & $0.37 \pm 0.09$ \\
\hline
\end{tabular}




\begin{tabular}{|c|c|c|c|c|c|c|}
\hline black-capped chickadee & $0.30 \pm 0.20$ & $0.10 \pm 0.10$ & $0.03 \pm 0.03$ & $0.13 \pm 0.03$ & $0.30 \pm 0.20$ & $0.27 \pm 0.12$ \\
\hline black-throated green warbler ${ }^{3}$ & $0.00 \pm 0.00$ & $0.00 \pm 0.00$ & $0.00 \pm 0.00$ & $0.00 \pm 0.00$ & $0.00 \pm 0.00$ & $0.13 \pm 0.07$ \\
\hline blue jay & $0.00 \pm 0.00$ & $0.05 \pm 0.05$ & $0.00 \pm 0.00$ & $0.00 \pm 0.00$ & $0.00 \pm 0.00$ & $0.03 \pm 0.03$ \\
\hline blue-gray gnatcatcher & $0.03 \pm 0.03$ & $0.00 \pm 0.00$ & $0.00 \pm 0.00$ & $0.00 \pm 0.00$ & $0.00 \pm 0.00$ & $0.00 \pm 0.00$ \\
\hline blue-winged warbler ${ }^{1,2,3}$ & $0.07 \pm 0.07$ & $0.00 \pm 0.00$ & $0.48 \pm 0.06$ & $0.00 \pm 0.00$ & $0.00 \pm 0.00$ & $0.00 \pm 0.00$ \\
\hline broad-winged hawk ${ }^{3}$ & $0.00 \pm 0.00$ & $0.00 \pm 0.00$ & $0.00 \pm 0.00$ & $0.00 \pm 0.00$ & $0.00 \pm 0.00$ & $0.07 \pm 0.03$ \\
\hline brown creeper $^{3}$ & $0.00 \pm 0.00$ & $0.00 \pm 0.00$ & $0.00 \pm 0.00$ & $0.03 \pm 0.03$ & $0.05 \pm 0.05$ & $0.00 \pm 0.00$ \\
\hline brown thrasher ${ }^{1,3}$ & $0.03 \pm 0.03$ & $0.00 \pm 0.00$ & $0.00 \pm 0.00$ & $0.00 \pm 0.00$ & $0.00 \pm 0.00$ & $0.00 \pm 0.00$ \\
\hline brown-headed cowbird & $0.03 \pm 0.03$ & $0.00 \pm 0.00$ & $0.21 \pm 0.13$ & $0.03 \pm 0.03$ & $0.00 \pm 0.00$ & $0.03 \pm 0.03$ \\
\hline Canada warbler ${ }^{1,2,3}$ & $0.00 \pm 0.00$ & $0.00 \pm 0.00$ & $0.00 \pm 0.00$ & $0.03 \pm 0.03$ & $0.00 \pm 0.00$ & $0.33 \pm 0.07$ \\
\hline Carolina wren ${ }^{1}$ & $0.03 \pm 0.03$ & $0.05 \pm 0.05$ & $0.00 \pm 0.00$ & $0.00 \pm 0.00$ & $0.00 \pm 0.00$ & $0.00 \pm 0.00$ \\
\hline cedar waxwing $^{1}$ & $1.26 \pm 0.43$ & $0.55 \pm 0.55$ & $0.93 \pm 0.32$ & $0.20 \pm 0.06$ & $0.00 \pm 0.00$ & $0.07 \pm 0.07$ \\
\hline chestnut-sided warbler $^{1,3}$ & $0.00 \pm 0.00$ & $0.00 \pm 0.00$ & $0.07 \pm 0.07$ & $0.00 \pm 0.00$ & $0.00 \pm 0.00$ & $0.00 \pm 0.00$ \\
\hline chipping sparrow & $0.69 \pm 0.05$ & $0.35 \pm 0.05$ & $0.04 \pm 0.04$ & $0.03 \pm 0.03$ & $0.20 \pm 0.20$ & $0.00 \pm 0.00$ \\
\hline
\end{tabular}




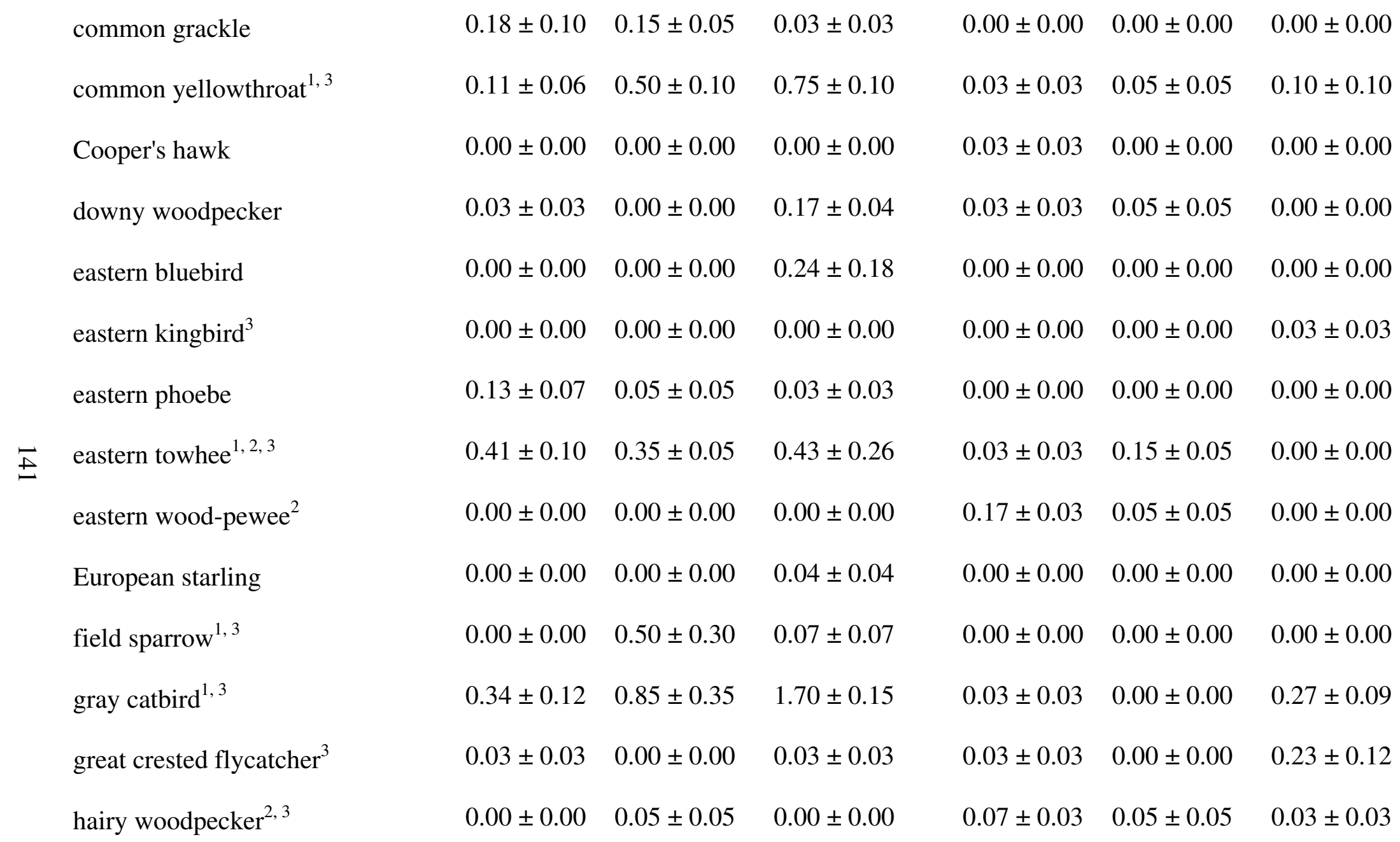




\begin{tabular}{|c|c|c|c|c|c|c|}
\hline hooded warbler ${ }^{3}$ & $0.00 \pm 0.00$ & $0.00 \pm 0.00$ & $0.00 \pm 0.00$ & $0.00 \pm 0.00$ & $0.00 \pm 0.00$ & $0.03 \pm 0.03$ \\
\hline house finch & $0.00 \pm 0.00$ & $0.00 \pm 0.00$ & $0.03 \pm 0.03$ & $0.00 \pm 0.00$ & $0.00 \pm 0.00$ & $0.00 \pm 0.00$ \\
\hline house wren ${ }^{1}$ & $0.04 \pm 0.04$ & $0.00 \pm 0.00$ & $0.03 \pm 0.03$ & $0.00 \pm 0.00$ & $0.00 \pm 0.00$ & $0.00 \pm 0.00$ \\
\hline indigo bunting $^{1,3}$ & $0.51 \pm 0.21$ & $0.15 \pm 0.05$ & $0.14 \pm 0.04$ & $0.00 \pm 0.00$ & $0.00 \pm 0.00$ & $0.00 \pm 0.00$ \\
\hline mourning dove & $0.11 \pm 0.06$ & $0.00 \pm 0.00$ & $0.04 \pm 0.04$ & $0.00 \pm 0.00$ & $0.00 \pm 0.00$ & $0.00 \pm 0.00$ \\
\hline northern cardinal ${ }^{1}$ & $0.03 \pm 0.03$ & $0.30 \pm 0.20$ & $0.00 \pm 0.00$ & $0.00 \pm 0.00$ & $0.00 \pm 0.00$ & $0.03 \pm 0.03$ \\
\hline northern flicker ${ }^{3}$ & $0.00 \pm 0.00$ & $0.00 \pm 0.00$ & $0.04 \pm 0.04$ & $0.00 \pm 0.00$ & $0.00 \pm 0.00$ & $0.00 \pm 0.00$ \\
\hline northern parula ${ }^{3}$ & $0.00 \pm 0.00$ & $0.00 \pm 0.00$ & $0.03 \pm 0.03$ & $0.00 \pm 0.00$ & $0.00 \pm 0.00$ & $0.00 \pm 0.00$ \\
\hline northern rough-winged swallow & $0.20 \pm 0.15$ & $0.00 \pm 0.00$ & $0.00 \pm 0.00$ & $0.00 \pm 0.00$ & $0.00 \pm 0.00$ & $0.00 \pm 0.00$ \\
\hline northern waterthrush ${ }^{3}$ & $0.00 \pm 0.00$ & $0.00 \pm 0.00$ & $0.00 \pm 0.00$ & $0.03 \pm 0.03$ & $0.00 \pm 0.00$ & $0.73 \pm 0.09$ \\
\hline ovenbird $^{3}$ & $0.00 \pm 0.00$ & $0.05 \pm 0.05$ & $0.00 \pm 0.00$ & $0.37 \pm 0.03$ & $0.30 \pm 0.10$ & $0.33 \pm 0.12$ \\
\hline pine warbler & $0.24 \pm 0.09$ & $0.00 \pm 0.00$ & $0.00 \pm 0.00$ & $0.03 \pm 0.03$ & $0.35 \pm 0.05$ & $0.10 \pm 0.06$ \\
\hline prairie warbler ${ }^{1,2,3}$ & $0.62 \pm 0.06$ & $0.50 \pm 0.00$ & $0.03 \pm 0.03$ & $0.00 \pm 0.00$ & $0.00 \pm 0.00$ & $0.00 \pm 0.00$ \\
\hline red-bellied woodpecker & $0.00 \pm 0.00$ & $0.00 \pm 0.00$ & $0.11 \pm 0.06$ & $0.00 \pm 0.00$ & $0.05 \pm 0.05$ & $0.00 \pm 0.00$ \\
\hline
\end{tabular}




\begin{tabular}{|c|c|c|c|c|c|c|}
\hline red-breasted nuthatch ${ }^{3}$ & $0.07 \pm 0.04$ & $0.00 \pm 0.00$ & $0.00 \pm 0.00$ & $0.00 \pm 0.00$ & $0.00 \pm 0.00$ & $0.00 \pm 0.00$ \\
\hline red-eyed vireo & $0.13 \pm 0.07$ & $0.10 \pm 0.10$ & $0.07 \pm 0.04$ & $0.50 \pm 0.00$ & $0.20 \pm 0.10$ & $0.03 \pm 0.03$ \\
\hline red-winged blackbird & $0.00 \pm 0.00$ & $0.50 \pm 0.50$ & $0.13 \pm 0.07$ & $0.00 \pm 0.00$ & $0.00 \pm 0.00$ & $0.00 \pm 0.00$ \\
\hline ruby-throated hummingbird ${ }^{1}$ & $0.03 \pm 0.03$ & $0.00 \pm 0.00$ & $0.24 \pm 0.07$ & $0.03 \pm 0.03$ & $0.00 \pm 0.00$ & $0.07 \pm 0.07$ \\
\hline scarlet tanager ${ }^{2,3}$ & $0.00 \pm 0.00$ & $0.05 \pm 0.05$ & $0.00 \pm 0.00$ & $0.20 \pm 0.06$ & $0.10 \pm 0.10$ & $0.00 \pm 0.00$ \\
\hline song sparrow ${ }^{1}$ & $0.14 \pm 0.04$ & $0.00 \pm 0.00$ & $0.07 \pm 0.03$ & $0.00 \pm 0.00$ & $0.00 \pm 0.00$ & $0.00 \pm 0.00$ \\
\hline tree swallow & $0.07 \pm 0.07$ & $0.10 \pm 0.10$ & $0.24 \pm 0.03$ & $0.00 \pm 0.00$ & $0.00 \pm 0.00$ & $0.00 \pm 0.00$ \\
\hline tufted titmouse & $0.17 \pm 0.09$ & $0.05 \pm 0.05$ & $0.07 \pm 0.07$ & $0.07 \pm 0.03$ & $0.00 \pm 0.00$ & $0.23 \pm 0.07$ \\
\hline veery & $0.04 \pm 0.04$ & $0.00 \pm 0.00$ & $0.03 \pm 0.03$ & $0.17 \pm 0.07$ & $0.25 \pm 0.15$ & $0.93 \pm 0.13$ \\
\hline white-breasted nuthatch & $0.03 \pm 0.03$ & $0.00 \pm 0.00$ & $0.00 \pm 0.00$ & $0.23 \pm 0.09$ & $0.05 \pm 0.05$ & $0.00 \pm 0.00$ \\
\hline white-eyed vireo $^{1}$ & $0.00 \pm 0.00$ & $0.00 \pm 0.00$ & $0.13 \pm 0.07$ & $0.00 \pm 0.00$ & $0.00 \pm 0.00$ & $0.00 \pm 0.00$ \\
\hline willow flycatcher ${ }^{1,3}$ & $0.00 \pm 0.00$ & $0.00 \pm 0.00$ & $0.04 \pm 0.04$ & $0.00 \pm 0.00$ & $0.00 \pm 0.00$ & $0.00 \pm 0.00$ \\
\hline winter wren ${ }^{3}$ & $0.00 \pm 0.00$ & $0.00 \pm 0.00$ & $0.00 \pm 0.00$ & $0.00 \pm 0.00$ & $0.05 \pm 0.05$ & $0.00 \pm 0.00$ \\
\hline wood thrush ${ }^{2,3}$ & $0.00 \pm 0.00$ & $0.00 \pm 0.00$ & $0.03 \pm 0.03$ & $0.13 \pm 0.09$ & $0.00 \pm 0.00$ & $0.00 \pm 0.00$ \\
\hline
\end{tabular}




$\begin{array}{lcccccc}\text { yellow warbler }^{1,3} & 0.03 \pm 0.03 & 0.15 \pm 0.05 & 0.99 \pm 0.12 & 0.00 \pm 0.00 & 0.00 \pm 0.00 & 0.00 \pm 0.00 \\ \text { yellow-billed cuckoo }^{1,3} & 0.07 \pm 0.03 & 0.00 \pm 0.00 & 0.00 \pm 0.00 & 0.00 \pm 0.00 & 0.00 \pm 0.00 & 0.00 \pm 0.00 \\ \text { yellow-rumped warbler }^{3} & 0.00 \pm 0.00 & 0.00 \pm 0.00 & 0.00 \pm 0.00 & 0.00 \pm 0.00 & 0.05 \pm 0.05 & 0.00 \pm 0.00 \\ \text { yellow-throated vireo }^{3} & 0.00 \pm 0.00 & 0.00 \pm 0.00 & 0.00 \pm 0.00 & 0.00 \pm 0.00 & 0.05 \pm 0.05 & 0.00 \pm 0.00\end{array}$

${ }^{1}$ Young forest species (Schlossberg and King 2007).

${ }^{2}$ High continental or regional priority in southern New England (Dettmers and Rosenberg 2000).

$\underset{+}{ }{ }^{3}$ Greatest conservation need in Rhode Island (RIDEM 2005). 